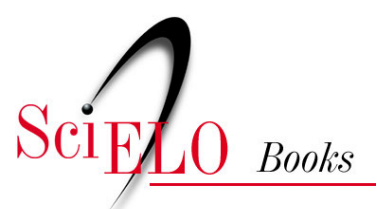

\title{
Gestão e avaliação de risco em saúde ambiental
}

\author{
Ogenis Magno Brilhante \\ Luiz Querino de A. Caldas \\ (coord.)
}

BRILHANTE, OM., and CALDAS, LQA., coord. Gestão e avaliação de risco em saúde ambiental [online]. Rio de Janeiro: Editora FIOCRUZ, 1999. 155 p. ISBN 85-85676-56-6 Available from SciELO Books <http://books.scielo.org>.

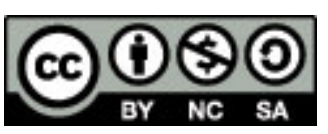

All the contents of this chapter, except where otherwise noted, is licensed under a Creative Commons Attribution-Non Commercial-ShareAlike 3.0 Unported.

Todo o conteúdo deste capítulo, exceto quando houver ressalva, é publicado sob a licença Creative Commons Atribuição Uso Não Comercial - Partilha nos Mesmos Termos 3.0 Não adaptada.

Todo el contenido de este capítulo, excepto donde se indique lo contrario, está bajo licencia de la licencia Creative Commons Reconocimento-NoComercial-CompartirIgual 3.0 Unported. 

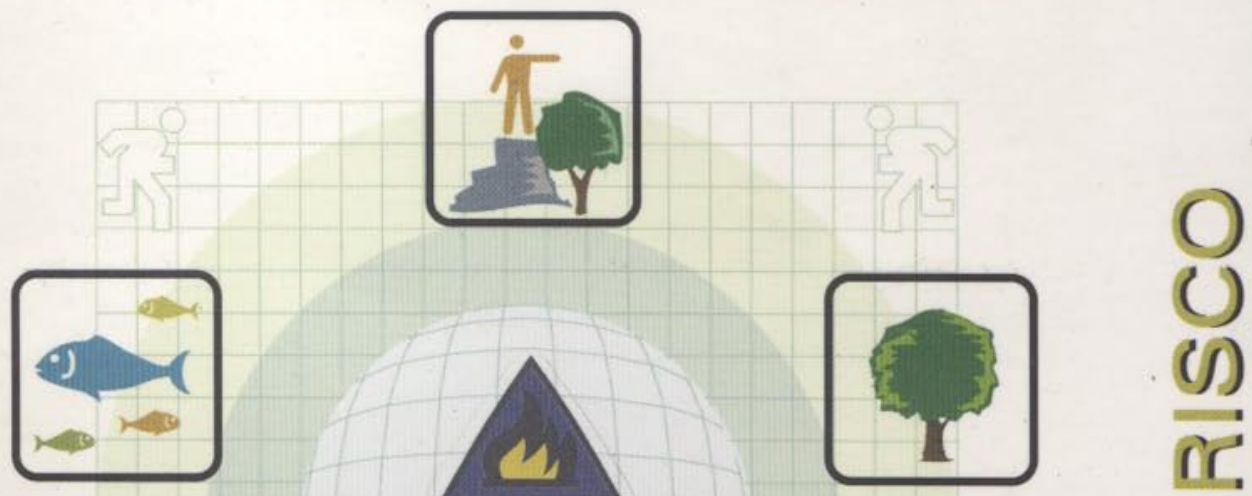

त.
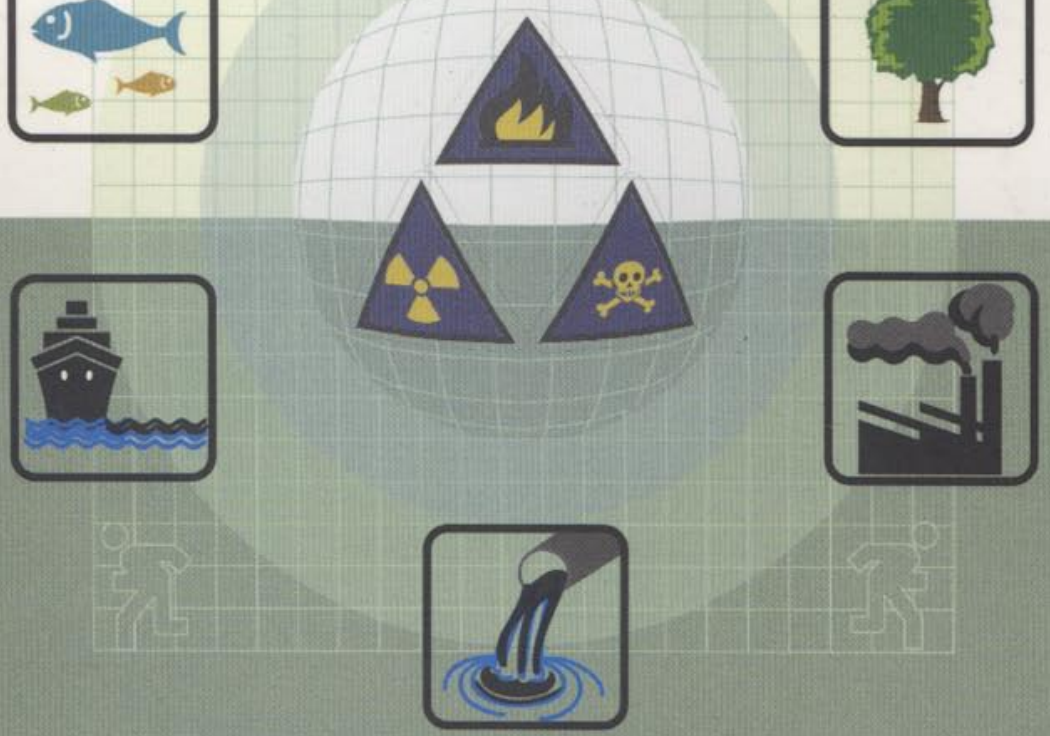

Coordenadores

Ogienis Magno Brilhante

Luiz Querino de A. Caldas

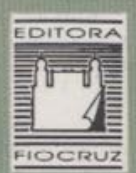

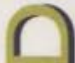

O

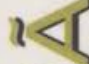

(c)

$\therefore<$

$=$

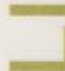

$<$

$\rightarrow$

$<$

III

O

$2<$

10

(j)

III

(ن)
4

11

1

III)

in

$>$

III

(

(1)

$<$

$\sum_{\text {III }}$ 


\section{GESTÃo E AVALIAÇÃO DE RISCO EM SAÚDE AMBIENTAL}




\section{FUNDAÇÃOOSWALDOCRUZ}

Presidente

Paulo Marchiori Buss

Vice-Presidente de Desenvolvimento Institucional, Informação e Comunicação

Paulo Gadelha

\section{EDITORA FIOCRUZ}

Coordenador

Paulo Gadelha

Conselho Editorial

Carla Macedo Martins

Carlos E. A. Coimbra Jr.

Carolina M. Bori

Charles Pessanha

Gilberto Hochman

Jaime L. Benchimol

José da Rocha Carvalheiro

José Rodrigues Coura

Luis David Castiel

Luiz Fernando Ferreira

Maria Cecilia de Souza Minayo

Miriam Struchiner

Paulo Amarante

Vanize Macêdo

Coordenador Executivo

João Carlos Canossa P. Mendes 


\title{
GESTÃO E AVALIAÇÃO DE RISCO EM SAÚDE AMBIENTAL
}

\author{
OGENIS MAGNO BRILHANTE \\ $\&$ \\ LUIZ QUERINO DE A. CALDAS \\ (Coordenadores)
}

Segunda reimpressão

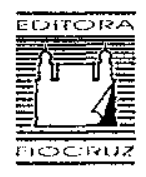


Copyright $^{\oplus} 1999$ dos autores

Todos os direitos desta edição reservados à

FUNDAÇÃO OSWALDO CRUZ / EDITORA

\section{ISBN: $85-85676-56-6$}

1" edição: 1999

la reimpressão: 2002

$2^{\Perp}$ reimpressão: 2004

Projeto gráfico, capa e editoração:

Ruben Fernandes

Copidesque e preparação de originais:

Marcionílio Cavalcanti de Paiva

Revisão:

Fernanda Veneu

Supervisão editorial:

Walter Duarte

Catalogaçãos-na-fonte

Centro de Informação Científica e Tecnológica

Biblioteca Lincoln de Freitas Filho

B857g Brilhante, Ogenis Magno (coord.)

Gestão e avaliação de risco em siúde ambiental. / coordenado por Ogenis Magno Brilhante e

Luiz Querino de A. Caldas.

- Rio de Janeiro : Editora FIOCRUZ, 1999.

$155 p$., il., tab., gralf.

1. Saúde ambiental. 2. Política ambiental. 3. Análise de risco.

1. Caldas, Luiz Querino de A. (coord.).

CDD - 20.ed. -363.7

2004

EDITORA FIOCRUZ

Av. Brasil, $4036-1^{9}$ andar - sala $112-$ Manguinhos

21040-361 - Rio de Janeiro - RJ

Tcls: (21) 3882-9039 e 3882-9041

Fax: (21) 3882-9006

e-mail: editora@fiocruz.br

http://www.fiocruz.br/editora 


\section{AUTORES}

\section{OGENIS MAGNO BRILHANTE}

Engenheiro sanitarista, doutor em ciência ambiental pela Universidade Paris XII (França); professor-visitante da Faculdade de Engenharia de Processos e Gestão Ambiental da Universidade de Delft (Holanda); professor e pesquisador associado do Departamento de Saneamento e Saúde Ambiental da Escola Nacional de Saúde Pública/Fundação Oswaldo Cruz (ENSP/Frocruz); coordenador de projetos de pesquisa, consultor e professor de disciplinas de mestrado e doutorado na área da poluição, impacto e risco na saúde ambiental; autor de diversos trabalhos publicados em periódicos nacionais e estrangeiros, com participação em vários congressos científicos internacionais.

\section{LUIZ QUERINO DE ARAÚJO CALDAS}

Médico e biólogo, mestre em farmacologia e professor de toxicologia; doutor pela Universidade de Bradford (Inglaterra), atua na área da saúde ambiental, foi consultor permanente do Centro Pan-Americano de Ecologia Humana e Saúde, da Organização Pan-Americana da Saúde (ECO/Opas/OMS); pesquisador-visitante da Escola de Saúde Pública da Universidade de Harvard (EUA) e Coordenador do Centro de Controle de Intoxicaçōes da Universidade Federal Fluminense (UFF).

\section{LENE HOLANDA SADLER VEIGA}

Bióloga, mestre em biofísica pela Universidade Federal do Rio de Janeiro; pesquisadora da Comissão Nacional de Energia Nuclear (CNEN) no Departamento de Proteção Radiológica Ambiental, atuando na área de avaliação de risco de poluentes radioativos e não-radioativos à saúde humana. Autora de diversos trabalhos publicados em periódicos nacionais e estrangeiros, com participação em vários congressos científicos internacionais. Desenvolveu trabalhos de cooperação na Área de Avaliação de Risco com o Oak Ridge National Laboratory (EUA).

\section{HORST MONKEN FERNANDES}

Engenheiro, doutor em geoquímica ambiental pela Universidade Federal Fluminense; pesquisador da Comissão Nacional de Energia Nuclear, consultor da Agência Internacional de Energia Atômica; coordenador de Projetos de Avaliação de Impactos Ambientais por substâncias tóxicas com ênfase na área de mineração e sistemas hídricos; autor de diversos trabalhos publicados em periódicos nacionais e estrangeiros, com participação em vários congressos científicos internacionais; representante da CNEN no Comitê de Certificação Ambiental (CCA). 



\section{SUMÁRIO}

Prefáclo

9

Apresentação 13

1. Gestão e Avaliação da Poluição, Impacto e Risco na Saúde Ambiental 19 Ogenis Magno Brilhante

2. PROCEDIMENTOS INTEGRADOS DE RISCO E GERENCTAMENTO AMBIENTAL:: PROCESSOS E MODELOS . 75 Horst Monken Fernandes \& Lene Holanda Sadler Veiga

3. Risco Potencial em Toxicologia Ambiental 93 Luiz Querino de A. Caldas

4. Avaliaçāo de Risco para a Saúde Humana e Ecossistemas . 119 Lene Holanda Sadler Veiga \& Horst Monken Fernandes

GLosSÁRIO 145 



\section{PREFÁCIO}

São muito antigos, na História da humanidade, os primeiros registros sobre as relações entre ambiente e saúde. Os perigos que cercavam o consumo de água e alimentos contaminados, por exemplo, estão na Bíblia e em documentos egípcios e gregos ainda mais remotos.

Também a saúde pública, desde seus primórdios, assim como a própria medicina, ocuparam-se das relações do ser humano com o meio ambiente.' Utilizando enfoques variados, de Hipócrates aos dias de hoje, as ciências da saúde têm procurado as causas, os modos de transmissão e a prevenção das doenças no hábitat humano.

Segundo Canguilhem, ${ }^{2}$ é possível identificar duas concepçōes básicas sobre doença que se alternam na História: a da doença como desequilíbrio do organismo ou quebra de harmonia com o meio ambiente e a concepção ontológica da doença como um ser ou algo que penetra no ser humano $\mathrm{e} o$ adoece. Em ambas, de qualquer forma, $\mathrm{o}$ ambiente joga $\mathrm{o}$ seu papel, pois no primeiro caso, trata-se de uma desarmonia com o mejo a ser enfrentada; no outro, algo ou um ser estranho, proveniente de fora, do ambiente que o cerca, produz no interior do ser a doença e a morte.

John Snow, com o seu clássico Sobre a Maneira de Transmissão do Cólera, ${ }^{3}$ de 1854, funda a epidemiologia e marca o início de uma nova era na análise das condições de saúde e doença dos grupos humanos. Seu tema, como sabemos, a descoberta das 'relaçōes perigosas' entre o ambiente contaminado (a bomba d'água de Broad Street) e a terrível e devastadora infeç̧ão intestinal produzida pelo vibrião colérico na população londrina.

A revolução pasteuriana, que consagra a teoria do germe no final do século passado e representa uma das mais notáveis contribuiçōes científicas na História da humanidade, talvez possa ter produzido, em alguns de seus seguidores de mentalidade mais estreita, a certeza de que tudo estivesse resolvido no longo e doloroso percurso do adoecer e do morrer humano, com a idéia da unicausalidade e da resolução dos problemas com o ataque aos germes no organismo humano, através de substâncias que a moderna ciência iria produzindo. Na realidade, Pasteur e seus seguidores, com muita argúcia, jamais ignoraram o papel do meio ambiente, propondo a clássica tríade agente-hospedeiro-ambiente para explicar o processo de transmissão dos germes recém-descobertos.

Oswaldo Cruz enfrenta, no início do século, no Brasil, com soros, vacinas e reforma urbana, $4: 5 ; 0$ através de uma intensa ação sobre o meio ambiente, as epidemias que ameaçavam fechar o País ao comércio exterior e devastar a economia nacional e não apenas as vidas humanas, como vinham fazendo.

Entralgo, P. L. Historia de la Medicina. Barcelona: Salvat, 1978.

Canguil.hem, G. O Normal e o Putológico.o. Rio de Janeiro: Forense Universitária, 1978.

Snow, J. Sobre a Maneira de Transmissão do Cólera. São Pauto/Rio de Janeiro: Hucitec/Abrasco, 1990.

Costa, N. Lutas Urbanas e Contmile Sanitário. Petrópolis: Vozes/Abrasco, 1985.

Fraga, C. Vida e Obra de Osvaldo Cruz. Rio de Janeiro: J. Olympio, 1972.

Britro, N. Oswaldo Cruz: a construçūo de um mito na ciência brusileira. Rio de Janeiro: Ed. Fiocruz. 
O mundo começa a despertar para a questão ambiental, de forma intensa e global, apenas há cerca de 30 anos. Em 1972, as Naçōes Unidas convocam a Conferência de Estocolmo, "que levou os países em desenvolvimento e os industrializados a traçarem, juntos, os 'direitos' da família humana a um meio ambiente saudável e produtivo". 7 Vinte anos após, no ciclo de grandes conferências que visam a preparar o mundo para o século XXI, a ONU convoca a RIO-92, Conferência das Nações Unidas sobre Meio Ambiente e Desenvolvimento, que produz dois documentos básicos para orientar ambientalistas, cientistas, ativistas e a população em geral: a Agenda 2 I e a Carta da Terra. ${ }^{x}$

Antecedendo a Conferência RIO-92, duas importantes inicialivas no que tange à saúde e ambiente desenvolvem-se no plano global: a implantação da Comissão Mundial sobre Meio Ambiente e Desenvolvimento, que gera um documento de primeira linha, Nosso Futuro Comum, tido como o grande inspirador das deliberaçōes havidas entre os Chefes de Estado presentes na Conferência do Rio; e a realização da III Conferência sobre Promoção da Saúde, em Sundsvall/Suécia, em 1991, com o tema dos "ambientes favoráveis à saúde"."

Todos correm para apresentar seus documentos de posição e influir nos resultados da RIO-92. A Organização Mundial da Saúde (OMS) produz Nosso Planeta, Nossa Saúde, ${ }^{10}$ que se transforma num marco para aqueles que atuam na confluência dos dois temas, saúde e ambiente. A própria Escola Nacional de Saúde Pública da Fundaçāo Oswaldo Cruz (ENSP/ FIOCRUz), preparou e lançou, à época, um dos mais completos documentos sobre o assunto: Saúde, Ambiente e Desenvolvimento," coletânea de 28 artigos, em dois volumes, reunindo quase 70 autores de diversils instituiçōes do País.

Toda esta história é importante para poder registrar os avanços que se vão produzindo na já longa trajetória de políticas, estudos e práticas na área de saúde e ambiente. As instituiçōes acadêmicas têm dado sua inestimável colaboração para o progresso, seja das políticas, seja dos conhecimentos imprescindíveis para o desenvolvimento de práticas efetivas neste campo.

O livro que ora prefacio, de Ogenis Magno Brilhante \& Luiz Querino de A. Caldas, dois professores da Escola Nacional de Saúde Pública, inscreve-se na melhor tradição dos estudos que reúnem fundamentos conceituais e inovaçōes. De fato, trabalham com um tema de ponta, contemporâneo e fascinante: o risco em saúde ambiental. Mas não o fazem com diletantismo acadêmico, senão com o objetivo do manejo do risco, vale dizer; com avaliação e gestão dos mesmos.

Aliam, neste Gestäo e Avaliação de Risco em Saúde Ambiental, as bases conceituais que permitem uma boa introdução àqueles que desejam iniciar-se no tema - com a apresentação de inovações metodológicas ainda não aplicadas em nosso país.

7 Comissão Mundial subre Mejo Ambiente e Desenyolyimentu. Nosiso Futumo Comum. Rio de Janeiro: Ed. FGV, 190!.

8 Conferencia das Nacóes Unidas sobre Meiu Ambienje e Desenvolvimento. Agenda 21 e Curta da Terru. Brasilia: Senado Federal, 1996.

9 World Health Organization (WHO). Creatisg Supportive Euvimments for Health. Geneva: WHO, 1990.

10 World Health Organization (WHO). Our Planet, wur Healih: report of the WhO Commixion on Health and Environment. Geneva: WHO, 1992.

II Leal. M. C. el al. Saüde, Ambieme e Desemolvimemo. São Paulo/Rio de Janeiro: Hucitec/Abrasco. 1992. $2 \mathrm{v}$. 
Como defendem os autores, "a avaliação de risco é um processo analítico muito útil, que gera valiosas contribuições para a 'gestão' do risco", scja pelas organizações de saúde pública, seja por aquelas responsáveis pela política ambicntal.

A essa altura, vale lembrar a estratégia da 'intersetorialidade'. De fato, o enfrentamento de problemas no campo da saúde e ambiente só vai ser efetivo se articular, de forma harmônica, complementar e integrada, disciplinas, profissionais e órgãos pelo menos dos dois setores governamentais envolvidos; assim como, se grupos de interesse da sociedade civil, envolvidos com a temática da saúde e do ambiente, conseguirem estabelecer alianças mutuamente benéficas para a luta por leis e normas exaradas dos Legislativos e pela implementação de políticas públicas favoráveis à saúde e ao ambiente, por parte dos Executivos.

Os autores têm uma preocupação adicional de grande relevância: adaptar as propostas de avaliação de risco para a realidade do nosso país. Completam o estudo discutindo o tema da gestīo ambiental, informada pela avaliação de risco.

Pelo somatório de tais elementos, este livro traz enormes contribuições e avanços para um tema de ponta, que é a confluência da saúde e ambiente. Da primeira experiência da ENSP, em 1992, com o curso sobre "Gestāo de Risco em Saúde Ambiental", até agora, o grupo avançou enormemente. Vão-se cumprindo etapas, como esta, na direçãa de objetivos maiores como o que se aproxima para a ENSP: preparar, na sua recém-criada Escola de Governo em Saúde, profissionais para a gestăo da saúde ambiental, com a base científica da avaliação de risco. 



\section{APRESENTAÇÃO}

O meio ambiente se constitui hoje um dos temas essenciais de política governamental c uma das maiores preocupações dos cidadãos, seja nos países industrializados ou não. A consciência política e social neste assunto é ụm fato. Cada vez mais um número maior de pessoas vê na degradação ambiental uma ameaça à saúde e ao bem-estar social.

Atualmente, um grande número de especialistas dos mais variados campos da ciência se ocupa da proteção da saúde humana. $O$ enfoque tradicional da saúde pública atual se combina com os modernos conceitos da interdependência da saúde com os fatores ambientais, o qual podemos denominar de saúde ambiental.

Todos os problemas relativos aos contaminantes ambientais estão, de uma maneira ou de outra, associados ao crescente processo de industrialização verificado desde o final do século passado, onde, ao lado do incremento da pesquisa, do desenvolvimento e da difusão de novas tecnologias, os processos de produção e seus produtos, têm contribuído para pôr em perigo ou causar prejuízos à saúde do homem e dos ecossistemas.

Estes contaminantes ambientais são, na atualidade, denominados de riscos tecnológicos ambientais e estão classificados em dois grupos: os riscos tecnológicos, aqueles decorrentes das atividades desenvolvidas pelo homem e os riscos naturais, os oriundos de distúrbios da natureza. Os primeiros podem ser controlados tanto na probabilidade de ocorrência quanto nas consequiências, ao passo que os segundos, em geral, não podem ser controlados no que se refere à probabilidade de ocorrência, somente nas suas consequiências.

Estes riscos, especialmente os tecnológicos, têm provocado grandes transformações em nosso planeta, causando alterações em escalas locais: contaminação por radiação, por produtos químicos e névoa ácida nos grandes centros urbanos; em escalas regionais ou continentais: chuvas ácidas; em escala global: destruição da camada de ozônio e efeito estufa.

Há um crescente consenso de que os problemas de saúde ambiental só serão resolvidos ou minorados com o desenvolvimento e a aplicação de políticas ambientais claras e eficientes, em que o princípio do desenvolvimento sustentável seja aplicado na solução das questões de meio ambiente, economia e sociedade. O processo de avaliação de risco ambiental é um instrumento metodológico importante para a execução de uma política de saúde ambiental.

Tal processo está sendo usado para satisfazer uma grande gama de propósitos, entre os quais auxiliar na gestão do risco e propiciar subsídios aos órgãos reguladores para tomada de decisões.

A avaliação de risco é um processo analítico muito útil que gera valiosas contribuiçōes para a gestão do risco, da saúde pública e para a tomada de decisões de política ambiental. Foi desenvolvida porque os agentes regulamentadores e a opinião pública exigiram que os cientistas fossem além da pura observaçăo das relações entre exposição a poluentes e seus efeitos nas populações e no meio ambiente, para responder a questões sociais sobre o que não é seguro. 
O primeiro código de procedimentos para a avaliação de risco em saúde foi estabelecido nos Estados Unidos, em 1983, pela Academia Nacional de Ciências (National Research Council - NRC).' Este procedimento, internacionalmente reconhecido, é dividido em quatro partes e foi desenvolvido para caracterizar os efeitos adversos de agentes na saúde humana, particularmente oriundos da exposição aos químicos: identificação do risco; avaliação dose-resposta; avaliação da exposição e caracterização do risco.

Ainda nos Estados Unidos, o rápido desenvolvimento tecnológico teve como consequiências o aparecimento de inúmeras situações de risco e o surgimento de vários sítios contaminados que fizeram com que a opinião pública pressionasse o Congresso a tornar mais rígidas as leis e os procedimentos de controle e prevenção do risco (os chamados superfunds). Para isto foi instituída pelo Congresso, em 1990, uma Comissão encarregada de fazer ampla investigação sobre as implicações políticas e o uso apropriado da avaliação e da gestảo do risco nos programas de regulamentação das leis para a prevenção de câncer e de outros efeitos crônicos à saúde humana, oriundos da exposição a substâncias perigosas. A comissão publicou, em julho de 1996, um relatório no qual é proposta uma nova padronização para a avaliação de risco (Commission on Risk Assessment and Risk Management, 1996). ${ }^{2}$ Este novo processo engloba o estudo do risco causado por vários contaminantes, compartimentos, fontes de exposições, assim como os valores sociais, percep̧̧ōes e ética, que tem como objetivo maior a gestão do risco.

Os seguintes componentes são incluídos neste novo procedimento: formulação de problema em um contexto amplo; análise dos riscos; definir as opções; tomar decisões; propiciar meios para que as decisões sejam implementadas (intervenções) e fazer uma avaliação da efetividade das açōes implementadas.

A comissão também reconhece que avanços importantes têm sido feitos no desenvolvimento científico do processo de avaliação de risco. Desenvolvimentos futuros irão melhorar ainda mais o reconhecimento e o cálculo dos riscos a que os humanos estão expostos quando em contato com produtos químicos ou outros agentes do meio ambiente, e prover marcadores biológicos para medir a exposição, os efeitos indutores e a variação na suscetibilidade. A comissão reconhece ainda que os riscos provenientes da exposição a micróbios e a radiações (e não somente a agentes químicos) precisam ser mais estudados.

No Brasil, um dos únicos programas que trata do assunto 'risco' foi regulamentado em 1995, pelo Ministério do Trabalho, e carece de abrangência na área da saúde ambiental.

Das agências regulamentadoras espera-se, por exemplo, o controle do risco do aparecimento de câncer e de outras doenças, e/ou que estes sejam reduzidos a níveis suficientemente baixos.

1 World Health Organization (WHO). Environmental and Health, The European charter and commentary. In: First European Conference on Environment and Health, Frankfurt, 7-8 Dec. 1989. Regional Publication. European Series, 35, 1990.

2 Commission on RisK AsSESSMENr and Risk Management. RiskA,ssessment and Risk Management in Regulatory Decision-making. Draft Report for Public Review and Comment, June 13, 1996. 
Para que isto seja conseguido, algumas questōes fundamentais devem ser respondidas: O que significa risco ambiental, risco à saúde e risco à segurança? Por que são importantes? Quais as similaridades entre os conceitos de meio ambiente, a saúde e a segurança; quais as diferenças? Por que estudamos meio ambiente, saúde e segurança em circunstâncias separadas e não de forma integrada? Quais os procedimentos existentes para identificar e avaliar os riscos associados com o meio ambiente, a saúde e a segurança? Como podem esses riscos ser sistematicamente analisados e identificados? Se identificados, quais os métodos disponíveis para remediá-los? O leitor mais atento encontrará, em cada capítulo deste livro, subsídios que poderão responder a estas questões e ajudar a identificar, analisar e, em algumas situações, contribuir para a tomada de decisão concernente ao problema da área.

No entanto, quando trabalhamos com a gestão de risco, precisamos saber a maneira de usar os recursos disponíveis na avaliação de risco, na análise econômica, na coleta de informações sociais e culturais, com a finalidade de melhorar seu manejo, torná-lo mais eficiente e mais transparente aos olhos do público para que se obtenha redução dos riscos a menores custos.

Enfrentamos um enorme desafio para administrar eficientemente os riscos à saúde associados com o vasto espectro da poluição gerada pelas atividades no planeta.

Como exemplo, vale lembrar que os poluentes introduzem no meio ambiente substâncias ou formas de energia passíveis de causar danos à saúde humana, aos recursos biológicos $\mathrm{e}$ sistemas ecológicos, ao patrimônio estético-cultural e ao uso futuro dos recursos naturais.

Após sua emissão por uma fonte qualquer, os poluentes percorrem diversos caminhos, em sua difusão no ambiente, até chegarem ao solo, ar e/ou água. Seu nível de concentração em cada ponto do percurso dependerá de diversos fatores: taxa de emissão, características de dispersão (em função das propriedades do poluente e do meio) e taxa de remoção do meio por agentes físicos, químicos e/ou biológicos ao longo de todo o percurso. A interação entre poluente e meio receptor resulta em um efeito cuja natureza, escala e importância, bem como a sua variação ao longo do tempo, são elementos que denotam a complexidade do tema.

Ao considerar o destino de substâncias perigosas, há que se pensar que estes materiais, emitidos na atmosfera, sem critério, são resultantes de qualquer processo de operação destinado ao seu desuso e/ou destruição. Subentende-se então que estes não vão ser reutilizados, recuperados ou reciclados. Portanto, ficarão disponíveis em algum compartimento da natureza ou permanecerão no ambiente até a sua disposição final.

Neste caso, quem se ocupará do processo e da gestão de avaliação de risco para o ambiente e populações que porventura estejam expostas?

Resíduos de substâncias perigosas e risco toxicológico constituem um novo capítulo na História da sociedade contemporânea, que soube fazer mas não soube dispor de seus dejetos. Quais os perigos para o ecossistema? Quais os danos efetivos? Quem são os culpados - existem culpados?

À parte dos direitos humanos, hoje poucas são as sociedades desenvolvidas (ou não) que se preocupam em manejar, tratar ou destruir os resíduos que produzem, sejam de ori- 
gem artesanal, industrial ou comercial, o que, até entāo, nas sociedades primitivas os próprios ecossistemas naturais se encarregavam de destruir ou reciclar. Com o passar dos anos, décadas, a progressiva saturação dos mecanismos de degradação do ambiente tem tornado cada vez mais exígua a destruição ou reciclagem destes pela natureza.

Ao longo da evolução do conhecimento, a História nos tem proporcionado preocupaçōes tão antigas como os ensinamentos que nos deixou Hipócrates, 300 anos a.C. Em seu livro, Ares, Águas e Lugares, teccu comentários teóricos sobre as inter-relações entre enfermidade $\mathrm{c}$ ambiente, com opinião definitiva sobre o papel do ambiente contaminado na saúde e no bem-estar dos cidadãos. Ainda que na medicina tenhamos construído, por séculos, a noção de domínio e primazia da raça humana, somente nas últimas décadas tomamos consciência da estreita interação homem-ambiente e sua importância no componente saúde, seja individual ou coletivo.

A realidade biológica dos fatos tem sido cientificamente revelada pari passu, sem que exista qualquer contestação a sua obviedade. Como assinala Leaning, ${ }^{3}$ não há como negar a dependência dos seres humanos do meio ambiente em que vivem. $\mathrm{O}$ ciclo $\mathrm{O}_{2}-\mathrm{CO}_{2}$, os ritmos circadianos, as influências eletromagnéticas ou mesmo a gratificação e os bencfícios mentat e espiritual são exemplos inexoráveis da necessidade de convivência harmônica do ser humano com a natureza.

Seria uma grande falácia considerar que nossa capacidade de adaptação está muito adiante de outros seres do mundo animal e que, portanto, somos imunes às mudanças climáticas, às disfunções dos ecossistemas naturais ou às forças vivas e limitações ambientais que definem o curso de nossas vidas.

A humanidade, segundo Carson, ${ }^{4}$ na busca incessante de riqueza, bem-estar e progresso está destinada a sucumbir, por assim dizer, nos seus próprios dejetos, devido a um crescente ineremento da atividade industrial e econômica global e, por conseguinte, da presença de numerosos xenoquímicos não degradáveis no ambiente.

Em seu curso normal, a natureza é capaz de renovar-se. Entretanto, à medida que os processos de acumulação antropogênica (principalmente) de substâncias químicas ultralpassam os limites de reciclagem do ambiente, ou se introduzem novos compostos nãodegradáveis, haverá, sem dúvida, um grande transtorno dos sistemas biológicos. Desta forma, novas estratégias de trabalho devem contemplar o estudo do risco químico. Muitos problemas que hoje enfrentamos são resultado de mais de 200 anos de práticas impróprias de manejo de substâncias perigosas de origem diversa.

3 Lisning, J. The medical consequences of environmental degradation. In: Symrosium Lectuke, Great Boston-PSR: Harvard University/MIT, Oct. 1992. 4p.

4 Carson, R. Silent Spring. Boston: Cambridge Press (Reimpressão). Dec. 1987, 1995. 
Uma tentativa não muito bem-sucedida de implantar a Avaliação de Risco em Saúde Ambiental foi feita pelo Ministério da Saúde que, dentro de sua Divisão Técnico Normativa, criou um setor que recebeu o mesmo nome, cujo primeiro diretor, dr. Roque Monteleone, divulgou e tentou conscientizar as autoridades sobre a importância desta ciência emergente na área da saúde ambiental, em particular na de toxicologia. $\mathrm{Na}$ época, proferiu palestras e promoveu reuniões para discutir a aplicação, pelo menos rudimentar, destes conhecimentos no Brasil. Porém, em nosso país, somente na década de 90 implementaram-se os primeiros estudos sobre a Análise de Risco em Toxicologia.

Nos primeiros anos, poucos eram os profissionais nacionais que dominavam amplamente o tema. Algumas consultorias já se aventavam a desenvolver programas de controle e gestão de risco, mas bem ao estilo do risco ocupacional voltado para coeficiente de gravidade, taxas de morbi-mortalidade e acidentes nos ambientes de trabalho. Exercícios valiosos na área atuarial tiveram, porém, pouca repercussão para a saúde e para o meio ambiente. Em 1992, iniciamos na Escola Nacional de Saúde Pública, da Fundação Oswaldo Cruz, talvez o primeiro curso sobre Gestão de Risco em Saúde Ambiental no Brasil. Com duração de 50 horas, incluiu atividades no laboratório de informática da Escola. Nele, foram abordados seis principais temas:

- poluição, impacto e risco na saúde ambiental;

- avaliação econômica ambiental;

- avaliação integrada de risco e gestão ambiental;

- avaliação de risco para a saúde humana e dos ecossistemas;

- risco potencial em toxicologia ambiental;

- risco epidemiológico.

Em 1993, o curso foi repetido e mais bem adaptado às condições brasileiras, ou seja, vários exercícios executados durante sua realização foram relatos de casos de experiências aqui adquiridas. Nessa segunda oportunidade, $o$ interesse pelo assunto se multiplicou, fato demonstrado pela afluência de alunos de diversas partes do território nacional com um contingente de aproximadamente 50 participantes com diferentes formações profissionais.

Em 1994, houve uma interrupção formal do evento na Fıocruz, uma vez que a maioria dos docentes se afastaram de suas atribuiçōes para desenvolver atividades ligadas ao tema em instituições no País ou no exterior. Este foi o caso dos drs. Horst Monken Fernandes, Lene Holanda Sadler Veiga e dos coordenadores, drs. Luiz Querino de A. Caldas e Ogenis Magno Brilhante, em cujas biografias, resumidas no início desta obra, relatam seus recentes treinamentos na área.

O presente livro é fruto do amadurecimento de idéias e conceitos ministrados na época, com a incorporação de novas estratégias metodológicas e nova sistemática de trabalho neste campo, usualmente aplicadas em países desenvolvidos. Em sua essência, trata de evocar 
exemplos que podem ser empregados no cotidiano, conferindo a estes menos incertezas e mais balizamento científico. Todavia, é bom frisar que durante os trabalhos de revisão técnica e/ou elaboração do texto não soubemos de outra iniciativa que atendesse aos mesmos critérios propostos no curso, tampouco de entidades que se preocuparam com o assunto na área da saúde ambiental, lapso substancial para o desenvolvimento do tema em nosso país.

Ainda sobre esta matéria, existem várias definiçōes e abordagens conceituais sobre poluição, meio ambiente, impacto, risco e saúde. Neste livro, tais conceitos são apresentados de acordo com a experiência individual de cada um dos autores, isto é, meio ambiente, saúde, proteção radiológica e toxicologia ambiental. Assim, o leitor encontrará definiçōes que poderão parecer repetitivas, mas que na verdade denotam a ótica peculiar de cada tema. Isso não é um fato inusitado, pois recentemente especialistas da área formaram uma comissão especial justamente para tentar harmonizar os diversos procedimentos e conceitos existentes no assunto.

O livro é composto por quatro capítulos. No primeiro o leitor encontrará um conjunto de informações e conceitos sobre saúde ambiental, poluição, impacto e risco. As questōes da gestão e da política de saúde ambiental são amplamente discutidas, assim como também sāo apresentados o histórico, a evolução e os procedimentos para a execução de projetos de gestão e avaliação e risco em saúde ambiental. Com relação a este último item, o autor apresenta um modelo geral de risco com informações essenciais sobre o processo de análise de risco e das técnicas e métodos utilizados nas diversas fases da avaliação de risco. Finalmente, apresenta as semelhanças e diferenças existentes entre os estudos de impacto ambiental e os estudos de avaliação de risco e de saúde.

O capítulo 2 trata dos procedimentos integrados de risco e gerenciamento ambiental. Após breve introdução sobre princípios e definições, aborda a elaboração de cenários e modelos conceituais para o meio ambiente. Diversos exemplos, incorporando modelos matemáticos, fluxogramas e tabelas são apresentados e discutidos à luz do conhecimento atual.

Focalizando as questōes emergentes relacionadas ao risco potencial em toxicologia ambiental, o capítulo 3 discute alguns conceitos básicos sobre o tema, na visão do toxicologista, e relaciona a toxicogênese das substâncias perigosas como meio de discriminar e quantificar o risco químico tóxico. Apresenta, ainda, informações e exemplos que mostram as nuances envolvidas no processos de assessoramento do risco.

Finalizando este trabalho, o capítulo 4 divide-se em duas partes: a primeira faz uma apresentação minuciosa dos procedimentos existentes para avaliação de risco à saúde humana, que inclui os seguintes assuntos: critérios de toxicidade sistêmica, avaliação doseresposta, critério de toxicidade para carcinógenos e não-carcinógenos, avaliação da exposição e, finalmente, caracterização do risco. Na segunda, os autores descrevem o risco ecológico, discutindo problemas relacionados à redução da abundância e produção de algumas espécies e apresentando métodos e atributos do risco ecológico, no qual vários exemplos utilizando estudos quantitativos são exibidos. 


\section{1 \\ GESTÃO E AVALIAÇÃO DA POLUIÇÃO, IMPACTO E RISCO NA SAÚdE AMBIENTAL}

OGENIS MAGNO BRILHANTE

\section{Conceitos de Saúde Ambiental}

As correlações entre meio ambiente e outros fatores começaram a ser estabelecidas somente no final do século passado. A política relativa a meio ambiente se limitava, por assim dizer, à saúde pública. Até há pouco tempo, seu campo de atuação era quase totalmente voltado para a prevençāo e o controle de doenças infecciosas.

A tecnologia do século XX mudou radicalmente tal situação. Atualmente, vasta gama de especialistas dos mais variados campos da ciência se ocupa da proteção da saúde humana. $\mathrm{O}$ enfoque tradicional da saúde pública, hoje, se combina com os modernos conceitos da interdependência da saúde com os fatores ambientais (saúde ambiental) (WHO, 1990).

Esse novo enfoque reconhece que, em princípio, quase todos os aspectos do meio ambiente afetam potencialmente a saúde. Isto é verdadeiro não só para agentes específicos, como microorganismos ou outras entidades biológicas, forças ou agentes físicos e químicos, mas também para elementos dos meios urbano e rural: casas, locais de trabalho, áreas de lazer, infra-estruturas, indústrias; e os principais componentes do mundo natural, como a atmosfera, o solo, a água e as muitas partes da biosfera.

Essa complexidade e multidisciplinaridade causada pelo rápido desenvolvimento tecnológico, traduzido notadamente pelo aumento na utilização dos recursos naturais e na șíntese industrial de novas substâncias, requer que a questão da saúde seja tratada de forma integrada com os fatores ambientais e as questōes econômicas. A melhora da qualidade da saúde ambiental estará necessariamente ligada ao desenvolvimento de processos ecologicamente sustentáveis.

Hancock (1993) formulou um modelo de gestão de saúde ambiental, em que trata das relações entre saúde (incluindo fatores sociais), meio ambiente e economia. Em tal modelo, 
para que a cconomia tosse ambientalmente sustentável, seria necessário que a atividade econômica não utilizasse recursos renováveis - como plantas, animais e solo-, além dos seus limites de renovaçāo ou de recomposição (sustentabilidade); nāo deveria poluir o ar e os ecossistemas terrestres e aquálicos de tal forma que não pudessem se recompor; nem poderia perturbar ou desequilibrar a atmosfera ou outros ciclos e sistemas naturais até onde a viabilidade dos ecossistemas estivessem comprometidos.

Nesse modelo, a economia precisaria ser não somente ambientalmente sustentável, como também socialmente sustentável, conceito que inclui o princípio da equiidade e no qual a saúde humana depende não só da geração e distribuição eqüitativa da riqueza, mas de um meio ambiente viável. A viabilidade é, então, um conceito antropogênico, ligado não apenas à sustentabilidade da vida em geral, mas à criação de condiçōes que possam suportar a vida e, em particular, que propiciem uma boa qualidade de vida.

\section{Poluição e Meio Ambiente}

\section{Conceitos}

Não cstá ainda definido com exatidão o conceito de poluição, nem há divulgação correta do mesmo na esfera da população.Para uns, poluição é modifïcação prejudicial em um ambiente onde se encontra instalada uma forma de vida qualquer; para outros, essa forma de vida tem de ser o homem, e outros mais a entendem como alteração ecológica nociva, direta ou indiretamente, à higidez humana (Branco \& Rocha, 1987; Margulis, 1990).

No sentido em que a empregamos, 'poluição' é um neologismo. Em 1958, os dicionários de língua trancesa Larousse empregava o termo para designar profanação de um templo, e o Robert, em 1970, o utilizava no sentido de tornar alguém ou algo doente ou perigoso.

Do ponto de vista ecológico, poluição é definida como qualquer alteração da composição e das características do meio que cause perturbaçōes nos ecossistemas, ou ainda, como uma interferência danosa nos processos de transmissão de energia.

Consistc em distúrbios ambientais consubstanciados em fatos ou fenômenos desfavoráveis, diretos ou indiretos. Os primeiros compreendem ataques à saúde e aos bens, como a promoção de deslocamentos populacionais ou o desequilíbrio social, ou ainda, implicações na qualidade de vida, como a poluiçāo sonora e estética, entre outras inconvenientes.

Os distúrbios ambientais indiretos incluem intromissões nos sistemas biológicos naturais, como a diminuição da fotossíntese pela poluição atmosférica.

\section{Despoluiçāo, Custo da Poluição e Despoluir até Onde?}

O termo 'despoluição' apareceu somente no linal dos anos 70 e pode ser empregado no sentido de retirar do meio exterior aquilo que pode ser nocivo. Por exemplo, retirar da água o que pode ser prejudicial ao meio exterior ou para um uso específico. Esta definição 
envolve três coisas. Primeiro, que saibamos o que é preciso retirar, ou seja, o que é nocivo. Isto implica conhecimento do sentido de medir, da medição da despoluição e também do sentido das consequiências a longo prazo.

Para responder o que medir, apresentaremos o seguinte exemplo: a análise de uma água bruta normal pode revelar presença de centenas ou até de milhares de substâncias. Nessas condiçōes seria impossível analisá-las e medi-las. E depois, até onde medir? Isto é, deveríamos medir até que ordem: $\mathrm{mg} / \mathrm{L}$, micrograma/L ou nanograma/L? Agora, vejamos as seguintes situações: se desejamos que os peixes vivam nos rios, precisamos saber que tipo de peixe queremos - por exemplo, carpa ou truta. Se desejamos água de boa qualidade em um porto, precisamos saber se esta qualidade será a necessária para que o porto seja utilizado também como local de recreação - por exemplo, canoagem - ou para criar mexilhões para consumo humano. Assim, podemos perceber que existe uma vasta gama de utilização da água que pode mudar muito as coisas. No primeiro e segundo exemplos, se a utilização da água escolhida fosse para criar trutas e mexilhões, a qualidade destas águas deveria ser melhor que para as outras opções. Isto envolveria, por exemplo, um grau de despoluição maior e, consequientemente, a elevação dos custos.

\section{Geração e Controle da Poluição}

A geração e o controle da poluição abrangem uma complexidade de relações entre os vários fatores envolvidos nas diversas atividades humanas. Despoluir inclui custo financeiro importante e como os efeitos da poluição presentes e futuros não são precisamente conhecidos, fica difícil estimar cifras.

A identificaçăo e a definição dos componentes de um programa de controle da poluição é muito importante para auxiliar no planejamento e na gestão ambiental, e diversos autores já tentaram isso. Nesses trabalhos, a atividade produtiva e os grupos de pressões são atores valiosos. Na Figura 1, observa-se o modelo de controle da poluição proposto por Gilad (1979) c apresentado na série Public Health in Europe, 8.

O modelo parte do princípio de que toda atividade humana, seja produção ou consumo, produz resíduos, alguns dos quais podem ser reutilizados ou reciclados nos processos de produção (Figura 1, setas 1-3). Os resíduos que não podem ser reutilizados ou reciclados tornamse lixo depositado no meio ambiente, seja na sua forma original ou após passar por algum tipo de tratamento (Figura 1, setas 7-9). O meio ambiente tem uma certa capacidade natural de assimilar determinados tipos de dejetos sem causar efeitos negativos a si próprio (Figura 1, seta 10). Os dejetos não assimilados resultam em poluição (Figural, seta 11). Os efeitos conhecidos ou desconhecidos da poluição despertam uma reação do público (Figura 1, setas 12-13). Quando esta reação do público se torna importante, aparece no sistema a formulação de legislação específica ou, se no caso já existe uma, cresce a pressão para torná-la mais rigorosa (Figura 1, seta 14a). Tal legislação pode se tornar mais ou menos rigorosa em razão da intluência dos vários atores intervenientes no processo de geração da poluição (Figura 1, seta 15) e, assim, influenciar todo o processo. Algumas legislaçōes podem facilitar ou encorajar o aumento da reciclagem dos resíduos antes de estes se tornarem lixo; isto pode ser obtido por taxação dilerenciada, subsídios, instrumentos de mercado e outros meios. 
Pode-se, também, modificar o processo de produção ou o produto para se reduzir a quantidade de lixo produzido, ou ainda, pode-se mudar a sua composição, tornando mais fácil sua reciclagem dentro do processo de produção (Figura 1, setas 16-17). Outros tipos de legislações podem ainda determinar a aplicação de tratamentos mais eficazes ou prover subsídios, indultos etc. (Figura 1, seta 18).

Devemos ter em mente que o tratamento, por si próprio, não reduz a quantidade de resíduos, mas simplesmente reduz seu volume e, por meio de mudanças biológicas e físico/ químicas, torna mais fácil a sua dispersão ou assimilação. Alguns tipos de legislaçōes podem exigir o uso de métodos de dispersão e disposição com alto coeficiente de segurança, explicitando métodos de análises e parâmetros ambientais a serem rigidamente controlados (Figura 1, seta 19). Outros tipos de legislações também tentam regulamentar os níveis de poluentes permitidos, deixando poluidores e agências ambientais com liberdade de escother os métodos e a tecnologia necessária para se atingir os objetivos de poluição fixados (Figura 1, seta 20).

Quase todos os processos de redução da poluição têm elevado custo financeiro. A somatória dos custos acumulados em todas as medidas envolvidas na diminuição da poluição representa o valor total do controle da poluição (Figura 1, setas 21-22). Estes custos, quando repassados direta ou indiretamente para os preços dos produtos, interferem nas atividades produtivas e de consumo (Figura 1, seta 25 ). Isto, por sua vez, pode resultar no interesse do público ou na formação de grupos de pressão com o propósito de minimizar as despesas relacionadas à poluição, diminuindo assim a pressão sobre a atividade econômica (Figura 1, seta 26). Tais grupos pressionam tanto os legisladores quanto os órgãos de controle por mudanças na legislação com o fim de abrandá-la, torná-la mais restritiva ou rigorosa. No final, o sistema mantém o seu equilíbrio por meio do conflito entre os grupos de pressões e os grupos de interesses especiais; o processo político é essencial, nestes casos, para resolver tal questão.

Os efeitos presentes e futuros da poluição ambiental não são de todo conhecidos. Por isso o custo da poluição é muito difícil de ser estimado com grande exatidão. Assim, a análise pura e simples de custo/benefício não fornece subsídios completamente válidos para uma tomada racional de decisão (Figura 1, setas 101-105). 
FIGURA 1 - Modelo para controle da poluição

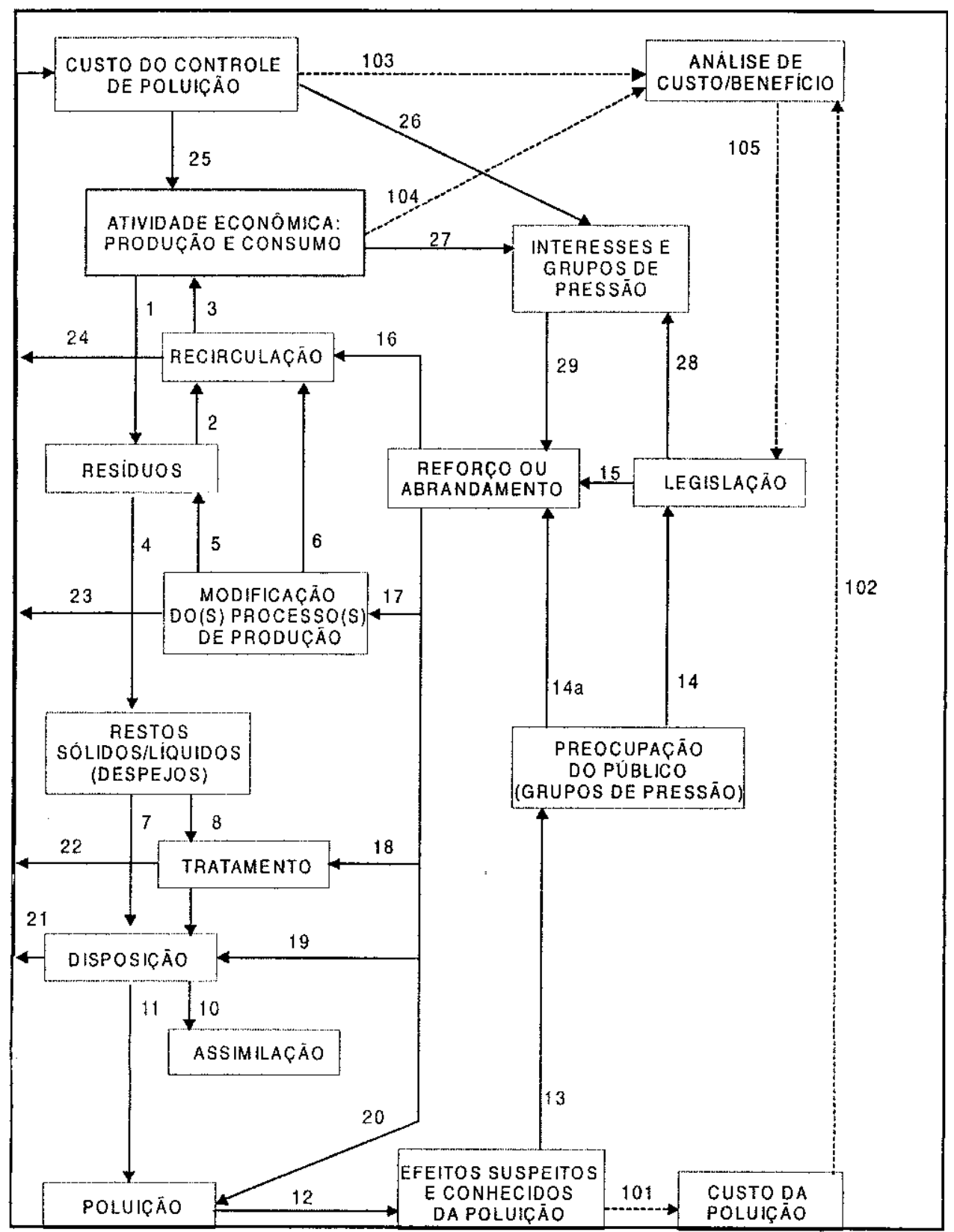

FONTE: GILAD (1979). 


\section{Conceitos de Meio Ambiente}

Existem vários conceitos para o neologismo 'meio ambiente', porém o que nos parece mais apropriado com o objeto deste capítulo é o postulado pelo Conselho Internacional da Língua Francesa:

Meio ambiente é um conjunto, a um dado momento, de agentes fisicos, químicos, biológicos e de fatores sociais suscetiveis de provocar um efeito direto ou indireto, imediato ou a termo, sobre os seres vivos e as atividades humanas.

Para melhor qualificar a ação do homem sobre seu meio é preciso definir os dois seguintes termos:

Alteragene: toda substância ou todo fator que provoque uma alteração do meio ambiente.

Perturbação: toda alteragene que comporte um risco notável para a saúde e a qualidade de vida do homem ou que pode lhe atingir indiretamente, através de repercussôes sobre o seu patrimônio cultural e economico.

Meio ambiente pode ainda ser definido como um meio físico suscetível de alteração pela atividade humana. Neste caso, ele é restrito à porção do espaço do sistema TerraAtmosfera, onde se realiza o conjunto de condições físicas que asseguram o desenvolvimento da vida e, mais particularmente, da vida humana. Este espaço é caracterizado pela presença de dois fluidos - $\mathrm{o}$ ar e a água - cujas propriedades permitem a distribuiçāo, ao nível do solo, da energia fornecida ao planeta pelo sol e, por conseguinte, da repartição dos climas, que, por sua vez, regula a circulação atmosférica e o ciclo da água. Compreende então, mais precisamente, a fina película atmosférica que envolve a Terra, as águas de superfícies continentais e marinhas, assim como as camadas superficiais do globo que servem de reservatório para as águas subterrâneas. O estado do sistema em um dado instante e a sua evolução com o tempo resultam das transferências de massa, de energia e da quantidade de movimento que existe entre a água, o ar e a Terra sob o efeito da energia solar.

\section{Meio Ambiente e Saúde Ambiental}

O meio ambiente está doente. Tal conclusão consta do relatório intitulado Que Meio Ambiente para o Amanhä?, publicado na Holanda (Ministerie van Volkshuisvesting, 1992), que trata das evoluções constatadas e previstas em escala nacional e internacional para o meio ambiente, durante o período de 1985 a 2010 . Neste relatório, o meio ambiente é considerado um sistema de reservatório e de reciclagem natural de todo tipo de matéria. O sistema é dividido em cinco níveis nos quais se produzem os efeitos da poluição, a saber:

- local: as aglomerações (meio ambiente no interior das aglomerações, perturbações sonoras e descontaminação dos solos); 
- regional: as paisagens (uso de fertilizantes, disposição de resíduos);

- fluvial: bacias dos rios e sistemas costeiros marinhos (uso de fertilizantes e desflorestamento);

- continental: correntes marinhas e atmosféricas (acidificação, smog);

- mundial: camadas superiores da atmosfera (deterioração da camada de ozônio, mudanças climáticas).

Muito embora cada nível conheça problemas de poluição específicos, estes estão ligados entre si. Por exemplo, os problemas locais podem criar outros em níveis superiores e vice-versa. Porém, quanto mais as perturbaçōes estão ligadas a um nível superior, mais lentamente seus efeitos se farão sentir. É por esta razão que somente uma abordagem em diferentes níveis poderá propiciar uma solução eficaz.

Uma rápida visão da situação do meio ambiente atual nos permite constatar os seguintes principais problemas:

- as chuvas ácidas continuam a se formar e grandes áreas de florestas estão hoje comprometidas;

- o teor de amoníaco proveniente principalmente da agropecuária não tem cessado de aumentar;

- a taxa de ozônio na troposfera, responsável entre outras pela formação do smog, está em elevação; a diminuição da camada de ozônio na estratosfera (10 a $15 \mathrm{~km}$ de altitude) não tem parado de crescer, provocado especialmente pela acumulação em alta altitude de substâncias dificilmente degradáveis como os clorofluorcarbonos (CFC).

- a rápida acumulação do dióxido de carbono proveniente, entre outros, da utilização de combustiveis fósseis, ameaça o planeta com o efeito estufa. As águas interiores contêm hoje, em alguns sítios, 10 a 15 vezes mais nitrato e fosfatos que os teores naturais, o que tem provocado proliferaçōes incomuns de algas, alterando o equilíbrio natural;

- a acumulação de metais e pesticidas, principalmente nos sedimentos dos corpos hídricos, têm trazido sérias conseqüências para os peixes, mamíferos e ecossistemas inferiores. As águas subterrâneas, o solo e grande parte das águas superficiais estão contaminadas pela presença de nitrogênio, fosfato e potássio proveniente em grande parte da agricultura.

- substâncias dificilmente biodegradáveis como os metais, pesticidas e outros com postos orgânicos constituem igualmente uma ameaça para a qualidade do solo e 
dos lençóis freáticos. No caso do solo, este é cada vez mais poluído por pesticidas, fertilizantes e depósitos atmosféricos, além dos lançamentos legais e ilegais de efluentes e resíduos sólidos diversos;

- a poluição sonora proveniente da circulação rodoviária, ferroviária e aérea tampouco tem cessado de aumentar.

Também pressiona o meio ambiente, além da poluição, a ameaça de extinção de recursos naturais vitais, dentro de alguns anos, aliada a um crescimento demográfico crescente e a melhora da qualidade de vida em certas regiōes do planeta. É o caso, por exemplo, das florestas tropicais e dos combustíveis fósseis. A continuar esse ritmo de consumo atual, os recursos naturais acumulados no curso de vários séculos serão exauridos em pouco tempo: 30 anos para o petróleo e cerca de 200 anos para o carvão, segundo alguns especialistas. Este processo será acompanhado pelo agravamento da poluição atmosférica, sonora, do solo e das águas, da desaparição maciça de espécies animais e vegetais, cujas consequiências a longo prazo são em grande parte desconhecidas e de difícil previsão.

Como exemplo, no Quadro 1 observa-se um resumo dos principais poluentes, suas origens, abundância e efeitos na saúde, presentes em alguns grandes centros urbanos do planeta. Nele aparece em destaque a importante contribuição do tráfego automotivo para a formação do coquetel de poluentes hoje existente nas grandes metrópoles e da poluição sonora como um considerável fator desse coquetel.

Um outro exemplo da poluição urbana causada por metais, em sua maioria oriunda do tráfego automotivo, é apresentada Gráfico 1. As concentrações dos metais foram obtidas através da análise, por absorção atômica, de material particulado atmosférico colhido ein um túnel de Paris. Além das elevadas concentrações de metais como chumbo, zinco, cádmio, cobre e manganês, uma análise mineralógica por meio da difração aos Raios X também mostrou a presença de grande quantidade de matéria orgânica e de compostos de ferro como a magnetita, a goetita, a hematita e de outros como mica, a kaolinita, a clorita e a calcita. Dessas partículas, $72 \%$ possuíam diâmetros inferiores a 5 micra, o que as classifica como partículas inaláveis, isto é, capazes de penetrar profundamente no sistema respiratório. 


\begin{tabular}{|c|}
\hline Poluentes \\
\hline
\end{tabular}

$\begin{array}{ll}\mathbf{P b}, \mathbf{C d}, \mathbf{C u}, & \text { Veículos, metalúrgicas } \\ \mathbf{Z n}, \mathbf{H g}, \mathbf{M n} . & \text { e galvanoplastia. }\end{array}$

Partículas pretas Indústrias de cimento, e brancas

$\begin{aligned} & \text { Adeídos } \\ & \text { (formaldeído e } \\ & \text { acetaldeído) }\end{aligned}$
Benzeno,
Metano,
Hidrocarbonetos
$\mathrm{SO}_{2}$

NOx

$\mathrm{CO}$

$\mathrm{CO}_{2}$

Ozônio

(baixa altitude) Reaço do $\mathrm{O}_{2}$ com 0 s NOx e hidrocarbonetos sob a ação do sol.

Asbesto

Material insulante, lonas de freios, telhas etc. minas, combus

Indústrias e produtos químicos, queima de combustíveis tósseis e de etanol.

Produtos químicos, gás natural, petróleo,

gasolina.

Combustāo de carvāo, petróleo, metalúrgicas, veículos.

Veículos, combustāo de petróleo.

Veículos, aciarías, combustão de petróleo e carvão.

Processos de combustāo e biodegradação.
Atacam o sistema nervoso, causam perda de mobilidade e memória, destroem os glóbulos vermelhos, cumulativos.

Degradam as vias respiratórias, aumentam a incidência de doenças respiratórias crônicas e o risco de câncer.

Suspeito de causar câncer, presentes nas névoas ácidas.

Sim

Diminuindo

Sim

Diminuindo

Efeitos indiretos na saúde humana, implicados no efeito estufa.

Câncer das vias respiratórias e digestivas, mutação.

Asma e chuvas ácidas.

Pouco

Aumentando

Sim

Diminuindo

Problemas respiratórios, chuvas ácidas, formação de $\mathrm{O}_{3} \mathrm{em}$ baixa altitude.

Sim

Diminuindo

Vertigens, dor de cabeça,

Sim

atacia o sistema nervoso central. Aumentando

Asma, irritação dos olhos e garganta.

Cicatrizes no pulmão, cancerígeno.
Sim

Aumentando

Sim

Aumentando

Sim

Diminuindo

Poluição sonora Diversas: veículos,

Perda gradativa da audição,

Sim lazer, indústrias etc. incômodo, irritabilidade, fadiga, Aumentando insônia, aumento da adrenalina no sangue, estresse, acidentes de trabalho, diminuição da capacidade de concentração. 


\section{GRÁFICO 1 - Suscetibilidade* e concentração média de metais de material particulado atmosférico}

(a) suscetibilidade; (b) chumbo; (c) zinco; (d) cádimio e cobre; (e) manganês.

Número de amostras: 10; metais: $\mathrm{mg} / \mathrm{kg}$, (massa da matéria seca)

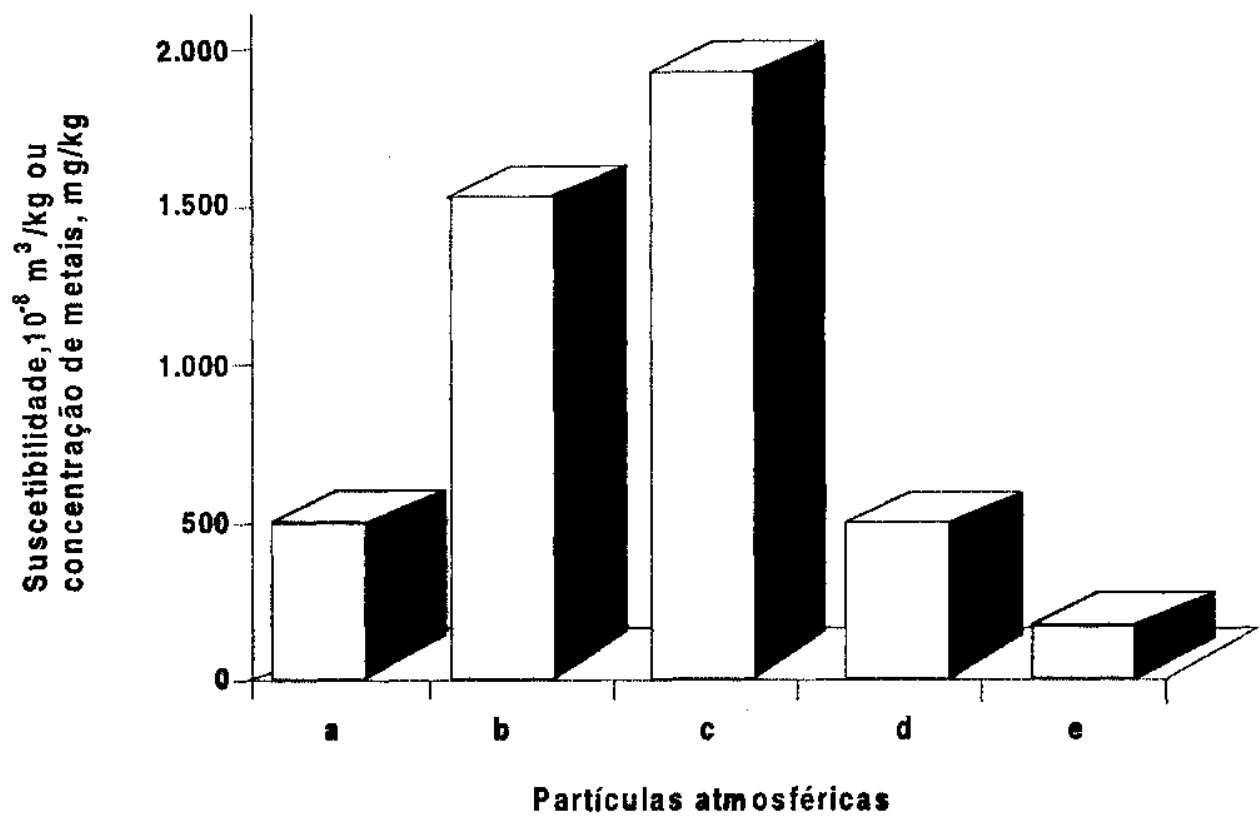

Fonte: Baluhante Resende (1995).

* Suscetibilidade magnética - tipo de análise magnética cujo resultado está associado à concentração total de metais presentes na amostra.

Outro grupo de poluentes também bastante comum no meio ambiente são os resíduos e produtos químicos.

Estima-se que a cada ano mais de mil novos produtos químicos são introduzidos na cadeia de produção industrial do planeta. Muitas dessas substâncias são tóxicas ou apresentam algum grau de risco. Para muitas delas, não dispomos ainda de suficientes conhecimentos sobre toxicidade, meios de prevenção ou de exposição.

No quadro seguinte apresenta-se pequena relação dessas substâncias facilmente encontradas no Brasil, juntamente com alguns dos efeitos causados à saúde. 
Acrilato de metila

Bifenila policlorada (PCBs)

\section{Hexaclorociclohexano (HCH)}

Pentaclorofenato de sódio

Negro de fumo

DDT

TCDD
Solvente usado em indústria de tintas e vernizes. Tóxico quando em contato com a pele, causa toxidez aguda quando ingerido. É inflamável e emite fumaças tóxicas.

Conhecido também como óleo ascarel. Usado em transformadores, é classificado como cancerígeno. Pode causar irritação da pele, infecções hepáticas, neurológicas ou bronquites crônicas.

Também chamado de pó de broca. Causa tonturas, dor de cabeça, irritação nos olhos, na pele e náuseas. Pode provocar cirrose e hepatite crônica. Usado como agrotóxico, foi utilizado no Brasil para o combate à malária.

Conhecido como pó da China. Conservante de madeira e violento herbicida e cupinicida. Quando inalado, provoca dor de cabeça, suor e febre. Em contato com a pele, causa queimaduras. Pode ser fatal.

É um resíduo típico de borracheiras. Pode provocar irritação nos olhos e nas vias respiratórias. Em exposição prolongada, causa antracose.

Pesticida clorado, usado no Brasil para o combate a pragas, hoje está proibido no País. Acumula-se nos tecidos gordurosos, resulta em danos aos nervos e causa a diminuição das células brancas do sangue.

Dioxina, poderoso desfolhante. Extremamente tóxico na forma concentrada. Causa danos aos rins, fígado e ao sistema nervoso, teratogênico e possivelmente cancerígeno.

Milhares de sítios contaminados por diversos resíduos químicos são conhecidos hoje no mundo. No Brasil, diversos casos têm sido relatados. Entre os mais conhecidos está o da 'Cidade do Meninos', sítio localizado no município de Duque de Caxias, Estado do Rio de Janeiro, onde uma fábrica de $\mathrm{HCH}$, pesticida organoclorado (Quadro 2), operou por alguns anos, sendo desativada em 1955, deixando parte de sua produção abandonada in natura, a céu aberto, nas suas proximidades. Com o passar do tempo, este pesticida foi espalhado pela chuva e a ação do vento, e até pela população, para ser comercializado como inseticida. Ao longo desse mesmo período, a população do sítio aumentou. Em 1994, aproximadamente mil pessoas ali viviam, incluídas as cerca de 300 crianças moradoras em um abrigo para menores carentes. Hortaliças diversas, fruteiras, vários tipos de animais, entre gado de corte, leiteiro e também centenas de pessoas ainda hoje estão presentes na área. Segundo Brilhante \& Oliveira (1996), o solo superficial de uma área de $100 \mathrm{~m}$ de raio, medido a partir das ruínas da fábrica, chamada de foco, possuía concentraçōes dos isômeros de $\mathrm{HCH}$ da ordem de milhares de ppb, tendo alguns pontos amostrados atingido $192.000 \mathrm{ppb}$ (Gráfico 2). 
Pontos amostrados na estrada que atravessa o sítio e que, segundo moradores, teria sido aterrado com resíduos de $\mathrm{HCH}$, também mostraram resultados da ordem de milhares de ppb (Grático 2). Concentraçōes elcvadas de isômeros de $\mathrm{HCH}$ foram encontradas em 31 amostras de pessoas, sendo 17 femininas (12-59 anos) e 14 masculinos (5-69 anos) vivendo na área-foco em torno da fábrica. Altas concentrações de $\mathrm{HCH}$ também foram medidas nos pastos utilizados como alimento para o gado. Casos de intoxicaçōes têm sido relatados e o perigo de contaminaçāo indireta via cadeia alimentar constitui-se problema para a saúde humana e ambiental.

GRÁFICO 2 - Concentrações dos isômeros de $\mathrm{HCH}$ no solo versus distância do foco. 'Cidade dos Meninos', Duque de Caxias, Rio de Janeiro

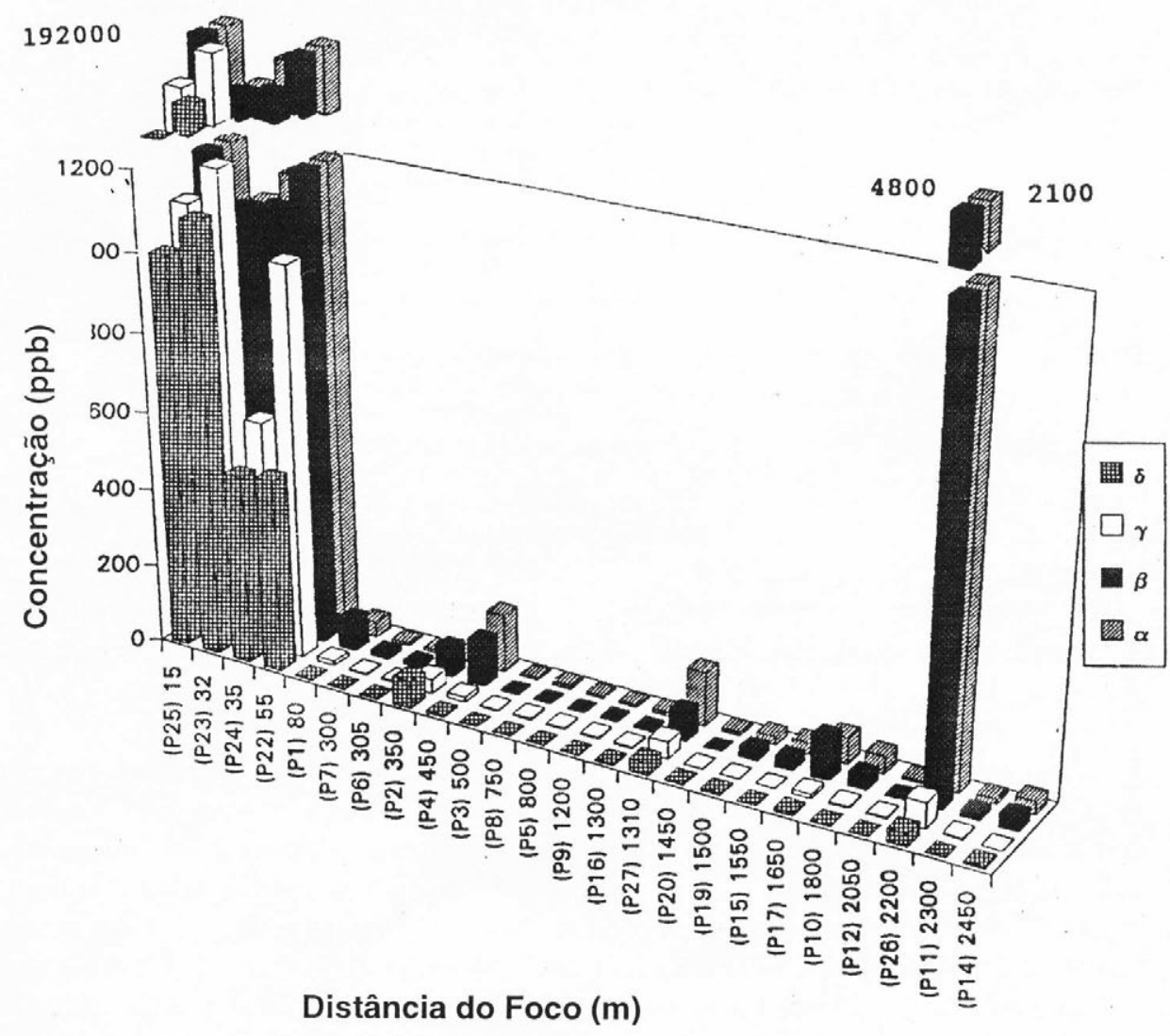

Fonte: Oliveira \& Brilhante (1995). 


\section{MeIo Ambiente e CÂNCER}

Muitos fatores são considerados capazes de aumentar o risco de câncer, como estilo de vida (fumo, álcool, dieta, comportamento reprodutivo) e fatores genéticos e hormonais. Os agentes ambientais também estão implicados e são, algumas vezes, relevantes em áreas e grupos populacionais especinis. Circunstâncias especiais como as encontradas em exposiçōes ocupacionais, práticas locais ou outras condições podem aumentar o risco do aparecimento de certos tipos de câncer, como os de pele e os do trato respiratório e urinário.

Quando consideramos as possíveis implicações da exposição de agentes ambientais e o aparecimento de câncer, uma distinção importante precisa ser feita entre dois grupos importantes de agentes: os carcinógenus genotóxicos - aos quais não existe limite mínimo de exposição - e os não genotóxicos, onde evidências têm sugerido que abaixo de um determinado limite, o risco do surgimento de câncer não existe.

Três importantes grupos de agentes ambientais, com suas possíveis implicações no aparecimento de casos de câncer, são descritos a seguir:

\section{- RAdIAÇÃo IONIZANTE}

Os efeitos na saúde da radiação ionizante têm sido um tópico de estudo há várias décadas. Incluem-se neste grupo as rochas contendo radônio e urânio, exposiçōes ocupacionais, acidentes e testes nucleares.

Estas radiações são consideradas carcinógenos genotóxicos e, portanto, não existe limite de exposição mínima para a indução do aparecimento de casos de câncer.

Estudos realizados na Suécia indicam que $16 \%$ de todos os casos de câncer de pulmão na população sueca podem ser atribuídos à exposição ao radônio (Pershagens, 1993).

A exposiçăo ocupacional é outra potencial fonte de risco. Entre as pessoas expostas estão os trabalhadores de minas, de indústrias nucleares, de equipamentos hospitalares e pesquisadores.

Acidentes nucleares estão também associados ao aparecimento de determinados tipos de câncer. A partir do acidente de Chernobyl, estudos de acompanhamento de saúde conduzidos em várias populações expostas aos radionuclídeos provenientes do reator sinistrado apontaram uma alta incidência de câncer da tireóide, em Belaurus, aparentemente devido à exposição a altas doses de radioiodine (Kazakov, 1992).

\section{- RADIAÇÖES NÄO-IONIZANTES}

A principal fonte de radiaçõos nĩu-ionizantes são os raios ultravioleta provenientes do sol (UVR) e de fontes artificiais, e os campos magnéticos, ambos de origem natural e artificial. 
A incidência de formas comuns de câncer de pele está aumentando de $2 \%$ a $3 \%$ ao ano. O melanoma maligno, uma forma rara de câncer de pele, com uma taxa de fatalidade de $30 \%$ a $50 \%$, tem crescido bastante nas últimas décadas. Isto está associado à diminuição da camada de ozônio, que deixa passar os componente mais perigosos do UVR solar (WHO, 1994).

Até o presente momento não se pode afirmar com absoluta certeza que a exposiçĩo ambiental aos campos magnéticos com baixas freqüuencias (ELF) causam efeitos biológicos adversos.

\section{- Químicos}

Ainda não se conhece com exatidão todo o potencial dos compostos químicos carcinogênicos. Assumido que não há limite mínimo de exposição para o aparecimento de câncer, a simples presença destes compostos no meio ambiente representa um risco potencial.

A atmostera é um dos principais transportadores destes produtos químicos. A exposição a produtos provenientes da queima incompleta de combustíveis fósseis contendo carcinógenos humanos como os hidrocarbonetos poliaromáticos (PAH) é relativamente comum. Em um estudo de caso-controle realizado em Cracóvia, Polonia, cerca de $4 \%$ dos casos de câncer de pulmão nos homens e $10 \%$ nas mulheres foram atribuídos ao fato de essas pessoas morarem em uma área com forte concentração de material particulado atmosférico (média anual de 150 microgramas por metro cúbico de ar) (Jedrychowski, 1990).

A inalaçāo passiva de tabaco foi recentemente implicada como fator contribuinte para o aparecimento de câncer de pulmão entre os não-fumantes que moram ou trabalham com pessoas que fumam em excesso. $O$ resultado de uma análise efetuada em 25 estudos epidemiológicos indicou um aumento do risco de $20 \%$ a $30 \%$ para os não-fumantes casados com lumantes (WHO, 1994).

A preocupação com o possível risco de contaminantes quínicos na água potável está diretamente ligada a certos pesticidas halogenados orgânicos (como os tri e tetracloroetilenos) c compostos inorgânicos (como os de arsênico e nitrato).

Nos alimentos, os compostos químicos que podem apresentar risco de câncer englobam um certo número de pesticidas, compostos orgânicos (como as bifenilas policloradas, as dibenzo p-dioxinas policloradas e os dibenzofuranos policlorados), compostos inorgânicos (como os nitratos e alguns metais) e toxinas naturais (como as micotoxinas do grupo allatoxin). 


\section{CONCEITOS DE IMPACTO}

Impacto é qualqquer alteração favorável ou desfavorável, produzida por um produto, processo, açẫo ou atividade (Bolea \& Estevan, 1984). Se esta altcração incide sobre o meio ambiente, chama-se impacto ambiental; sę ć sobre a saúde, chama-se impacto na saúde; se sobre a paisagem, chama-se impacto visual e assim por diante.

Para o Conselho Nacional de Meio Ambiente (ConAma, 1986), impacto ambiental é delinido como qualquer alteraçũo das propriedades físicas, químicas e biológicas do meio ambiente, causada por qualquer forma de matéria ou energia resultante das atividades humanas que, direta ou indiretamente, af etam: a saúde, a segurança e o bem-estar da população; as atividades sociais e econômicas; a biota; as condições estéticas e sanitárias do meio ambiente; a qualidade dos recursos ambientais.

Define-se, ainda, impacto de um projeto sobre o meio ambiente como a diferença entre a situação do meio ambiente futuro modificado, tal como resultaria depois de uma dada interferência, e a situação do meio ambiente futuro, tal como teria evoluído normalmente sem tal atuaçãa.

\section{Tipos de Impacto AMBIENTAL}

Os impactos ambientais podem ser de vários tipos. Podem ser diretos ou indiretos; produzir-se a curto ou a longo prazo; ser de curta ou longa duração; ser cumulativos; reversíveis ou não; ser inevitáveis; locais, regionais, continentais, globais; naturais e antropogênicos.

Um impacto ambiental direto ou primário é a alteração que sofre um atributo ou elemento ambiental devido à ação direta da natureza ou do homem sobre esse atributo.

Um impacto ambiental indireto ou secundário é a consequiência de um inpacto direto. Os impactos diretos são mais fáceis de se estimar, os indiretos, mais difíceis.

\section{IMPACTO GLOBAL: EFEITO ESTUFA E DESTRUIÇÃo DA CAMADA DE OZÔNIO}

\section{- EFEITO ESTUFA}

As atividades humanas têm produzido, ao longo das últimas décadas, uma elevação da concentração de certos gases que dificultam a dissipação da radiação refletida peli Terra. Esses gases, como o gás carbônico $\left(\mathrm{CO}_{2}\right)$ e o metano $\left(\mathrm{CH}_{4}\right)$, os clorofluorcarbonos (CFCs), o óxido nitroso e o ozônio atmosférico podem perturbar o equilíbrio energético entre a Terra e a atmosfera, c por conseqüência o nosso sistema climático. 
A indústria não é a única responsável por isso. Parece-nos que hoje mais da metade das fontes atuais de metano imputáveis às atividades humanas provêm das atividades agrícolas, como o cultivo de arroz (Lambert, 1992).

O clima da Terra varia naturalmente ao longo do tempo: ano após ano, no espaço de alguns milhares de anos ou sobre algumas centenas de milhares de anos. A humanidade, através de suas atividades industriais e agrícolas, tornou-se, gradativamente, um importante fator climático.

O desmatamento transforma radicalmente o conjunto da circulação atmosférica tropical, modificando assim o balanço hídrico e o regime das chuvas. Entretanto, o aumento da emissão dos gases com efeito estufa provocará, inelutavelmente, o aquecimento do planeta.

Qual será sua ordem de grandeza, sua distribuição geográfica, seu impacto e risco sobre os balanços hídricos regionais? Acerca disso, muitas incertezas e questões existem e precisam de respostas. Sabemos que no último século a temperatura da superfície do planeta aumentou em meio grau (Sadourny, 1992). Será isso um sinal do aquecimento anunciado? No momento não temos condições de responder, pois nenhuma prova existe, somente alguns indícios.

Como resultado dessas incertezas, de uma certa dose de hipocrisia e da falta de bom senso, 159 países e centenas de lobistas reunidos em Kyioto, no Japão, em dezembro de 1997, só conseguiram aprovar uma redução mínima dos gases responsáveis pelo efeito estufa: os EUA se comprometeram a reduzir suas emissões em 7\% até o ano 2012, a Europa em $8 \%$, enquanto os demais países em desenvolvimento - cerca de 136 -, não se comprometeram com nenhuma redução (The Economist, 1997).

\section{- Destruiçáo da Camada de Ozônio}

Há dois milhões de anos, o oxigênio $\left(\mathrm{O}_{2}\right)$ apareceu na atmosfera terrestre. Entre 20 e $30 \mathrm{~km}$ de altitude, em plena estratosfera, as radiações solares agem diretamente sobre ele, transformando-o em ozônio $\left(\mathrm{O}_{3}\right)$. Estas novas moléculas envolvem o planeta e o protegem contra os ataques do sol, absorvendo os raios ultravioleta.

Hoje sabemos que os clorofluorcarbonos, particularmente o $\mathrm{CFCl} 1\left(\mathrm{CFCl}_{3}\right)$ e o $\mathrm{CFC} 12$ $\left(\mathrm{CF}_{2} \mathrm{Cl}_{2}\right)$ são os majores responsáveis pela destruição da camada de ozônio.

Sintetizados pela primeira vez em 1930, os CFCs foram considerados produtos estáveis por muito tempo, aparentemente inertes e inofensivos. Providos de múltiplas propriedades, têm diversas utilizaçōes como líquido refrigerante e propulsor de aerossóis.

A partir dos anos 70, pesquisadores mostraram que, em altitude, sob o efeito das radiações solares, os CFCs tornaram-se grandes destruidores de ozônio. Trabalhos científicos mostraram que cada molécula de CFC, antes de ser inativada, pode destruir mais de mil moléculas de ozônio (Science \& Vie, 1991).

Na estratosfera, o ozônio é formado inicialmente quando uma molécula de oxigênio $\left(\mathrm{O}_{2}\right)$ absorve radiaçōes de ondas curtas, quebrando esta mesma molécula em dois átomos de oxigênio; cada átomo de oxigênio, por sua vez, se combina com outra molécula de oxigênio, formando assim o ozônio. Normalmente, as reações fotoquímicas são catalisadas pelos 
Nox, que removem o ozônio na mesma taxa em que os mesmos são formados. O ciclo catalítico do cloro, hoje aumentando rapidamente na atmosfera, perturba esse equilíbrio natural, provocando a diminuição da concentração de ozônio.

Atualmente a maior perda de ozônio tem se verificąo sobre a camada que cobre a Antártida, notadamente durante a primavera austral. Perdas têm sido medidas também sobre a camada do Ártico e dos grandes centros urbanos, inclusive a do Rio de Janeiro.

Essa diminuição de ozônio aumenta a incidência dos raios ultravioleta, responsáveis por diversos tipos de câncer de pele, Iesões oculares e enfraquecimento do sistema imunológico dos seres humanos. Ameaçam como um todo a saúde ambiental do planeta. Destruindo os vegetais verdes, precursores da vida sobre a Terra, esses raios terminarão por eliminar todas as espécies evoluídas.

Recentemente, a Organização Mundial da Saúde indicou estar havendo um aumento da incidência de câncer comum de pele na ordem de $2 \%$ a $3 \%$ ao ano. $\mathrm{Na}$ Inglaterra, a incidência do melanoma, um raro tipo de câncer, com fatalidade de $30 \%$ a $50 \%$, aumentou em $50 \%$ entre 1980 e 1986 (WHO, 1994).

\section{IMPACTO CONTINENTAL: CHUVAS ÁCIDAS}

A água da chuva nunca teve a pureza que o senso comum lhe atribui, mas o fato é que ela vem se tornando cada vez mais impura. A impureza natural consiste, sobretudo, na presença de sais marinhos. Mas os gases e fuligens que resultam das atividades antropogênicas interferem no processo de formação das nuvens, acidificando as chuvas. A queima de florestas também contribui para o fenômeno.

A precipitação das chuvas ácidas ou químicas em algumas regiões do planeta é uma das consequiências da poluição atmosférica, principalmente devido à interferência humana nos ciclos da biosfera. Uma chuva é considerada ácida quando o seu pH é inferior a 5,6. Uma vez precipitada no meio ambiente, atacam as florestas, matam os lagos, corroem monumentos e alteram a saúde do homem e dos ecossistemas.

Os principais gases envolvidos nos processos são os óxidos de enxofre (SOx) e os óxidos de nitrogênio (NOx), ambos provenientes principalmente da queima de combustíveis fósseis, como os derivados do petróleo e do carvão.

Estes óxidos, quando na presença da radiação solar e de catalisadores, formam, na atmosfera, os ácidos sulfúrico e nítrico, respectivamente. Ácido clorídrico e outros ácidos orgânicos são também formados. Entre os catalisadores, os metais e os hidrocarbonetos são essenciais ao processo.

\section{IMPACTO LOCAL: NÉVOA ÁCIDA (SMOG)}

Queimar vegetação, prática comum nos trópicos, emite partículas e vários gases, especialmente o dióxido de carbono $\left(\mathrm{CO}_{2}\right)$, hidrocarbonetos, óxido nítrico (NO) e dióxido de 
nitrogênio $\left(\mathrm{NO}_{2}\right)$. Esta e outras atividades humanas, tais como a queima de combustíveis fósseis, são em grande parte responsáveis pelo dramático aumento das concentrações desses gases na atmosfera, acarretando grandes perturbações, como o smog fotoquímico nos grandes centros urbanos.

O termo smog se refere a uma indescjável mistura de gases formados na baixa troposferal pela açẳo da lu\% solar sobre os poluentes de origem humana, especialmente os óxidos de nitrogênio (NOx) e hidrocarbonetos provenientes dos canos de escape dos veículos, produzindo gases reativos que podem ser nocivos aus organismos vivos.

O ozônio é o principal composto produzido no smog fotoquímico e o principal responsável pela irritação dos olhos, probicmas respiratórios, danos nas plantas e culturas vegetais e pela diminuição da vida útil dos pneus dos carros.

A intensidade do smog é geralmente medida pela concentração de ozônio presente ao nível do solo. No caso do smog fotoquímico, este está começando a aparecer também nos trópicos e subtrópicos, particularmente peli queima periódica de florestas e savanas (Graedel \& Crutzen. 1989). Tais prálicas emitem grandes quantidades de precursores do smog.

\section{DiferençAS ENTRE Impacto e Risco Ambiental}

Oefeito de um impacto pode ser positivo ou negativo. Já o efeito de um risco é sempre negativo, adverso.

Os estudos de risco incluem sempre o conceito de probabilidade; os de impacto, não necessariamente.

\section{Risco}

\section{Conceitos de Risco}

São vários os conceitos, mas um ponto comum entre cles é a inclusão da noção de probabilidiade. Para Conway (1982), risco é definido como a medida da probabilidade e da severidade de efeitos adversos; Inhaber (1982) o define como a probabilidade de ocorrer acidentes e doenças, resultando $\mathrm{cm}$ ferimentos ou mortes.

\section{O Significado do Risco}

O grau do risco é função do efeito adverso que pode resultar de uma ação particular. Entre os diferentes tipos de risco existentes, podemos citar o econômico, o de vida e saúde co risco ambiental. 
Riseo não é sinônimo de perigo. Deseer uma escada, por exemplo, representa um risco real de acidente. De fato, essa é uma das causas mats comuns de acidentes ocorridos em residêneias. Mas seria um tanto exitgerado chamar esse ato de perigoso.

Em nosso dia-a-dia estamos sempre expostos a riscos de acidentes. Se dirigirmos um carro, este pode abatroar ou ser abalroado. Se escolhermos anctar em uma calçada, podemos ser atropelados, e se permanecermos en casa e acendermos o fogâa a gás, há possibilidade de um incếndio.

A medicina tem tentado, com algum sucesso, reduzir o riseo - sem contanto tê-lo eliminado - de contrairmos doençaıs sérias. As pessoas ainda morrem de pneumonia, de Auss e por envenenamento, por exemplo.

\section{RISCO VERSUS BENEFÍCIO}

Como é impossivel eliminar o riseo, o melhor a lizer é tentar estabelecer uma comparatção entre o risco e us benelícios. Um número muito maior de pessoas morreria de lrio se o govemo banisse o uso de aquecedores a gás, por causa do risco de incêndios ou explosões. Nesse caso, o benefício ultrapassa o risco largamente e a decisão, desse modo, 1orna-se matis lácil.

Em relax̧ão ao uso da energia nuclear, torna-se mais difícil decidir. Entre os benefícios oriundos desse processo, comparado à geraf̧äo de eletricidade pela queima de combustíveis lósseis, podemos citar: menor produçĩu de poluentes precursores das chuvas ácidas e a ausêneia de morles de trabalhadores nas minas de exploração de carvão. Contudo, o processo nuclear não é isento de riscos. Limissão de poluiçẫo ou emisisóes calastrólicas de radiações, no calso de grandes acidentes e mortes de trabalhadores nas minas de urânio, podem acontecer.

\section{Como Expressar o Risco Matematicamente}

O uso de métodos de análises matemáticas do riseo fornece subsídios objetivos e racionais para auxiliar na tomada de decisĩo.

Una maneira de expressar o riseo matematicamente é por intermédio do uso da probabilidade. Esta está sempre entre os números zero e I. Um evento impossível de aconlecer tem probabilidade igual a zero, ao passo gue um evento certo de acontecer tem probabilidade igual a $\mathrm{l}$. Todos os outros casos se situan entre esses dois números.

Probabilidade é a proporção dos casos nos quais um evento ocorre. Por exemplo, a probabilidade de você jogar um diklo alo azar e obter um seis é de uma em seis. Podemos escrever essa probabilidade como $1 / 6$ ou 0,167 .

De acordo com Stewall (1990), a probalibidade de acontecer uma catástrofe numa usina nuclear - um acidente como o de Cherubyl, por exemplo - é de um em eada to mil 
anos, o que parece uma estatística bastante segura. Porém, se prestarmos mais atenção, o resultado é bem diferente. $O$ que esse número significa é que para cada reator nuclear, a probabilidade de que ocorra uma catástrofe em qualquer ano considerado é de um em 10 mil, ou ainda, de 0,0001 por ano. No caso da Inglaterra, por exemplo, existem cerca de 40 usinas nucleares funcionando. Portanto, a probabilidade de uma catástrofe ocorrer em peto menos uma dessas usinas, em um ano considerado, ć a soma das 40 probabilidades, ou seja, 0,004. A probabilidade de acontecer pelo menos uma catástrofe com essas usinas em um período de 25 anos é 0.1, ou seja, 25 x 0,004. Isto é, as chances sāo de uma em 10 . Esse resultado não parece tão confiável quanto o de um $\mathrm{cm} 10 \mathrm{mil}$ anos. Entretanto, esta é somente uma cntre as várias maneiras diferentes de se dizer a mesma coisa.

\section{Como Calcular o Risco}

Diariamente, aviões comerciais realizam um grande número de vôos: todo ano alguns caem. Podemos estimar a probabilidade de uma queda dividindo o número destas pelo número total de vôos. Quanto mais frecüente um evento ocorre, mais exato pode ser a cstimativa da sua probabilidade. No caso de um evento raro, a estimativa é bem mais difícil. Por excmplo, qual seria a probabilidade de um grande terremoto acontecer no Rio de Janeiro?

Ninguém jamais mediu ou presenciou tal coisa; nessas condições, podemos estimar em zero a probabilidade de sua ocorrencia. Mats isso pode ser apenas uma subestimativa. Ainda que os terremotos scjam mais raros no Rio de Janeiro do que por exemplo no Japão ou na Calilómia, não se pode descartar a hipótese de que eles possam acontecer. Portanto, a probabilidade de um grande terremoto ocorrer no Rio de Janeiro é muito baixa. Dizer de quanto ela é, então, é extremamente difícil.

Fontes inesperadas de risco, como por exemplo os CFCs, apresentam um nível ainda maior de problemas para se conseguir chegar a um cálculo exato. Antes de os produtores colocarem no mercado os CFCs como aerossóis, investigaram os possíveis efeitos desses agentes químicos no meio ambiente, incluindo o possível dano à camada de ozônio. Por serem usualmente estáveis e, portanto, não poder reagir com o ozônio atmosférico, os pesquisadores os escotheram. Infelizmente, ninguém previu que os cristais de gelo presentes na camada superior da atmosfera poderiam torná-los reativos. Se uma análise de risco omite um importante dano, seja porque não houve suficiente imaginação para considerá-lo ou por insuficiência de dados, seu resultado será inexato. Também de grande importância é a maneira como os pesquisadores coletam os dados e como estes são analisados.

No caso dos desastres, por exemplo, raramente têm uma causa única. Risco envolve cadeias de causas e efeitos, nos quais séries de eventos individuais se combinam para produzir um desastre. Para se calcular o risco combinado, é importante estimar as probabilidades dos eventos individuais. Uma técnica amplamente utilizada nestes casos é a construção de uma árvore de falhas. Trata-se de um diagrama que mostra as possíveis cadeias de eventos que icvam ao aparecimento de um dano. 
Um simples exemplo é o pára-quedas, no qual, em cada kit de aparelhagem, existe um pára-quedas principal e um reserva. $\mathrm{O}$ salto será fatal se pelo menos um deles não se abrir. Nesse caso, a árvore de falhas é uma cadeia de duas ligações. Se a probabilidade de falha de um pára-quedas é de uma em mil para cada um deles, então a probabilidade total é de uma em um milhão.

\section{ClassificaçÃo do RISCO}

- Risco ambiental - é o risco que ocorre no meio ambiente, seja ambiente interno no caso de uma indústria, por exemplo - ou externo. O risco ambiental pode ser classificado de acordo com o tipo de atividade (explosão, descarga contínua); exposição (instantânea,crônica); probabilidade de ocorrência; severidade, reversibilibilidade, visibilidade, duração e a ubiqüidade de seus efeitos (Sors, 1982). No concontex to da gestão governamental, o risco ambiental pode ser também classificado como: saúde pública, recursos naturais, desas tres naturais, e introdução de novos produtos.

Para a Organização das Nações Unidas para a Proteção Ambiental (United Nations Environmental Proteccion - UNEP), o risco pode ser classificado como:

- Risco direto - probabilidade de que um determinado evento ocorra, multiplicada pelos danos causados por seus efeitos.

- Risco de acidentes de grande porte (catástrofe) - caso especial de risco direto em que a probabilidade de ocorrência do evento é baixa, mas suas conseqüências são muito prejudiciais.

- Risco percebido pelo público - a percepção social do risco depende em grande parte de quem é responsável pela decisão sobre aceitá-lo ou não. A facilidade de compreensão e de aceitação do risco que se corre depende das informações fornecidas, dos dispositivos de segurança existentes, do retrospectivo da atividade e dos meios de informação.

Nas atividades industriais, podemos encontrar, ainda, dois tipos de riscos:

- Risco com características crônicas - aquele que apresenta uma ação contínua por longo período. Por exemplo, os efeitos sobre os recursos hídricos, a vegetação, o solo e a saúde.

- Risco agudo - decorrente de emissões de energia ou matéria em grandes concentrações, em um curto espaço de tempo. 
- Riscos tecnológicos ambientais (RTAs) - todos os problemas relativos aos contaminantes ambientais estão, de uma maneira ou de outra, associados ao crescente processo de industrialização verificado desde o tinal do século passado, em que ao lado do incremento da pesquisa, do desenvolvimento e da difusão de novas tecnologias, os processos de produção e seus produtos têm contribuído para pôr em perigo ou causar prejuízos à saúde do homem e dos ecossistemas. Esses contaminantes ambientais são, na atualidade, denominados de riscos tecnológicos ambientais e classificam-se em dois grupos:

- Riscos tecnológicos - os decorrentes das atividades desenvolvidas pelo homem.

- Riscos naturais - os decorrentes de distúrbios da natureza.

É fundamental ressaltar que os riscos de caráter tecnológico podem ser controlados tanto na probabilidade de ocorrência quanto nas conseqüências. Já os riscos de caráter natural, em geral, somente podem ser controlados no que se refere a suas conseqüencias (Awazu, 1990).

\section{ACEITAÇÃo do RISCO}

Alguém, em determinado momento, deve decidir se um risco é aceitável ou não. Mas o que é um risco aceitável? Uma resposta ruim para esta indagação seria: um risco é accitável se conseguirmos um benefício, enquanto outros sofrerão os efeitos. Estocar resíduos perigosos é ótimo, desde que seja mantido longe de mim. Um medicamento é 'seguro' se posso obter lucros por meio de sua venda e outras pessoas correm risco pelo seu uso.

Uma resposta melhor para este problema seria a de assumir que os benefícios deveriam suplantar os riscos para a maioria das pessoas que estivessem envolvidas. Muitos pensam que a conveniência de dirigir um carro supera o risco de se envolver em um sério acidente. Os que praticam esportes perigosos como corrida de carros, consideram que o prazer suplanta o risco - ou talvez subestimem o risco que correm.

A maneira como as pessoas reagem ao risco nem sempre reflete sua probabilidade. Por exemplo, a probabilidade de morrermos vitimados por um ataque terrorista $\mathrm{em}$ um aviāo é pequena, se comparada com a probabilidade de morrermos em um acidente de ônibus que faz o trajeto até o aeroporto. A maioria dos viajantes, contudo, está mais preocupada com o possível ataque terroristil (Stewarl, 1990).

A maltemática tampouco responde a essa questão. Pode, sim, nos dar uma boa idćia dos perigos envolvidos em alguma atividade $\mathrm{c}$, ainda, nos fornecer importantes subsídios para debate. O simples fato de que a malemálica produz pequenas probabilidades de riseo não significa que este seja imediatamente 'aceitável'.

Por exemplo, a fibra de asbesto pode causar uma doença fatal do pulmão. A probabilidade de contrairmos tal doença é bem pequena, no entanto, isto não significa que devamos 
continuar usando asbesto em várias produtos do nosso cotidiano, como telhas, freios etc. Em todo caso, o muito pequeno nem sempre é tão pequeno quanto parece. Em uma população de 40 milhões, uma doença com uma probabilidade anual de morte de um em um milhão matará 40 pessoas por ano. Novamente devemos usar nosso senso comum de julgamento: os números, por si só, não podem tornar decisões por nós.

Outro problema com alguns métodos de Avaliação de Risco são as inexatidões dos dados, que podem provocar erros bastante expressivos. A análise sensitiva é um método existente para calcular esses erros.

Finalmente, a maneira como os seres humanos reagem ao risco é influenciada também pelos fatores psicológicos. Trabalhadores de profissões perigosas quase sempre falham em tomar precauções. Estão tão acostumados ao perigo que passam a ignorá-lo. Mesmo se tomarmos precauçōes, estas nem sempre são benéficas como pensamos. Uma teoria conhecida como hipótese da compensação do risco afirma que as precauçōes com a segurança podem levar ao aumento da exposição ao risco (Stewart, 1990).

\section{Gestão e Avaliação da Saúde Ambiental}

\section{HistóRico e Conceitos}

Os problemas ambientais modernos são marcados pela diversidade, magnitude e complexidade, envolvendo aspectos políticos, sociais, de saúde e econômicos de grande relevância. Recebendo ampla cobertura dos meios de comunicação, esses problemas projetaram-se no centro das preocupações públicas, tornando-se símbolo de uma nova cultura e inscrevendo-se na agenda política mundial.

O gerenciamento de tais problemas era alé recentemente voltado para o meio ambiente local ou regional, restringindo-se quase sempre ao espaço das fronteiras nacionais. $O$ aparecimento de impactos de abrangências continentais e globais, como as chuvas ácidas e o efeito estufa, aliado a um rápido processo de globalização da economia e da informação, mostraram a necessidade de se expandir o gerenciamento ambiental em nível planetário. Um exemplo dessa nova estratégia são as convenções mundiais como a do clima, a da biodiversidade e o protocolo de Montreal sobre a camada de ozônio.

$O$ conceito moderno de gerenciamento ambiental não se limita somente às questões relativas à organização, mas incorpora também instrumentos de mercados e conhecimentos de diversas ciências como economia, engenharia, ecologia, meio ambiente, saúde, sociologia, segurança etc. Essa nova concepção de gestão multidisciplinar, na qual se reconhece que a saúde do homem e dos ecossistemas está na dependência dos fatores econômicos, sociais e ambientais, é chamada aqui de gerenciamento da saúde ambiental. Dentro dessa visão, fala-se, por excmplo, em saúde ambiental interna, relacionada à saúde do meio ambiente das indústrias/empresas, de ecossistemas industriais, isto é, da produção industrial baseada no funcionamento dos ecossistemas, ou ainda, da gestão de acidentes (desastres) e das políticas de desenvolvimento. 
A preocupação com o meio ambiente do planeta é recente. Só começou a tomar forma internacional a partir de 1972, quando aconteceu, em Estocolmo, Suécia, a la Conferência Mundial sobre o Meio Ambiente.

Anos depois foi formada uma comissão internacional encarregada de estudar e propor políticas para conciliar o meio ambiente com o desenvolvimento econômico. Tal comissão publicou, em 1987, um documento conhecido como Relatório Brundıland, que estabeleceu, pela primeira vez, uma correlação entre meio ambiente e crescimento econômico, também chamado de crescimento sustentável. Essa nova abordagem da questão ambiental foi referendada durante a $2^{\mathrm{a}}$ Conferência Mundial sobre o Meio Ambiente, realizada na cidade do Rio de Janeiro, em 1992. Neste evento as questōes de saúde, segurança e desenvolvimento social e econômico foram definitivamente incorporadas ao conceito clássico da gestão ambiental, hoje chamada de gestão da saúde ambiental. Um dos pontos centrais do gerenciamento da saúde ambiental, em nível macro ou micro, é o estabelecimento de uma política de saúde ambiental.

\section{Política de Saúde Ambiental}

O princípio do crescimento sustentável está hoje presente em todas as políticas ambientais, desde os níveis locais até o nível global. Pensar globalmente e agir localmente é um objetivo a ser perseguido.

A implantação de um programa de gestão da saúde ambiental, seja no nível micro ou macro, exige a definição prévia de uma política de saúde ambiental. Considerando-se devidamente os problemas e características políticas, sociais, econômicas e administrativas de cada país, pode-se dizer que é desejável que a política de saúde ambiental de qualquer nação parta de uma estruturação legal e institucional originada no poder federal ou central, com um caráter normativo. A definiçāo de objetivos e metas a serem atingidos em termos nacionais, assim como a fixação das prioridades e condiçōes necessárias para a participação de fundos tinanceiros nacionais ou internacionais nesses programas, deve estar claramente anunciados. Além disso, as legislações nacionais devem ser adaptadas constantemente aos princípios das convenções internacionais.

O conceito moderno de política ambiental (saúde ambiental) afirma que esta deve anunciar claramente os objetivos a serem perseguidos, o horizonte de tempo necessário para executá-los e os instrumentos para sua efetivação.

A maioria dos países desenvolvidos, notadamente os da Europa, como Holanda e Alemanha, possuem políticas ambientais claramente definidas, nas quais o princípio do desenvolvimento sustentável está consubstanciado através dos seguintes postulados:

- gestão integrada das cadeias de produção, centrada em um ciclo o mais hermético possível do material, criando um circuito fechado desde a matéria-prima até o resíduo, diminuindo as emissões, os despejos e a perda de matéria-prima; 
- utilização racional da energia, centrada sobre uma diminuição do consumo de combustíveis fósseis e um rápido aumento do uso de energias alternativas duráveis como o sol, o vento e a água;

- melhora da qualidade das matérias primas e dos produtos, para aumentar o tempo do ciclo de vida $\mathrm{c}$ assim reduzir os problemas causados pelos rejeitos no meio ambiente.

\section{HOLANDA: UM EXEMPLO DE POLÍTICA DE SAÚDE AMBIENTAL}

A Holanda tem, hoje, uma das políticas ambientais mais avançadas do planeta. É a que mais se aproxima do conceito de saúde ambiental proposto neste livro. Sua política ambiental é aprovada pelo parlamento e os horizontes de tempo para obtenção dos resultados esperados são claramente definidos. Apresentamos, a seguir, um resumo dessa política.

Seu objetivo é resolver os problemas de saúde ambiental, em princípio no prazo de uma geração, inspirando-se no conceito do crescimento durável. É fato aceito que este objetivo não será atingido para todos os tipos de poluiçōes existentes, pois enquanto uma parte das conseqüências dos danos se fará sentir dentro de algumas dezenas de anos, outra necessitará de muito mais tempo. Cientes destes problemas, os responsáveis optaram por um prazo intermediário, entre 20 e 25 anos, para controlar a situação ambiental e evitar sua continuada deterioração.

Três características norteiam essa política:

- uma dupla abordagem em nível dos efeitos e em nível das fontes de poluição, com uma clara preferência por esta última;

- uma que visa a responsabilizar os grupos-alvo pela proteção do meio ambiente. As empresas e os cidadãos devem assumir suas responsabilidades modificando comportamentos. Esta abordagem é justilicada pelo princípio segundo o qual as leis e as medidas de proteção ambiental só podem ser eficientes se a sua necessidade ou seu valor é percebido;

- a terceira característica visa à integração externa, a saber, a integração da dimensão ambiental com as outras políticas do poder público como agricultura, transporle, saúde, indústria, energia, educação, construção etc.

De acordo com o Plano Nacional do Meio Ambiente (National Milieu Policy -NMP), aprovado por aquele parlamento em 1985, espera-se alcançar os seguintes resultados até o ano 2010: redução das substâncias acidificantes de $60 \%$ a $80 \%$; a produção total de resíduos deve diminuir $\mathrm{em} 10 \%$, e $55 \%$ dos resíduos produzidos devem ser reciclados. Os fabricantes serão os responsáveis pelos resíduos de sua produção, o que implica que os mesmos deverão recuperar os produtos após sua utilização, para 
então reciclá-los. A utilização de pesticidas deverá ser reduzida à metade atć o ano 2000. Para resolver o problema de excesso de produção de rejeitos de animais, seria preciso que, em 1994, se tivesse tido a possibilidade de dar tratamento adequado a seis milhōes de toneladas, caso contrário, necessitar-se-ia reduzir-se o número total de animais no país. O crescimento da circulação automotiva deverá ser diminuído à metade, o cue envolverá uma diferente utilização dos veículos, aumentando-se o uso do transporte em comum. Para lutar contra as mudanças climáticas, os rejeitos de dióxido de carbono deverão ser estabilizados nos níveis medidos em 1994. A utilização dos CFCs foi praticamente encerrada em 1995 (Ministerie van Volkshuisvesting, 1992).

\section{Gestāo da Saúde Ambiental InTerna (Indústria)}

Pensar globalmente e agir localmente é hoje uma filosofia que está se expandindo rapidamente. Neste sentido, o gerenciamento ambiental interno, ou seja, da indústria, tem se desenvolvido intensamente. Dentro desta perspectiva, surgiu então o conceito da proteção do meio ambiente industrial, abrangida pelo princípio da qualidade total, que reçuer, ao lado dos objetivos quantitativos de produção, a consideração de metas para diversas outras variáveis, como cliciência, custos, segurança c qualidade dos produtos.

Proteger o meio ambiente passou a ser objetivo comum e perınanente de todos os setores da empresa, contemplado no quadro de objetivos múltiplos prioritários e traduzido em cuidados ambientais, de saúde e de segurança ao longo de todas as operações industriais, com reflexos nas matérias primas selecionadas, produtos, processus, instalações e práticas de trabalho.

Nos últimos anos foram tomadas várias iniciativas destinadas a estabelecer um padrāo de gerenciamento ambiental aplicável por diferentes segmentos econômicos. Assim, a partir da norma Britânica BS7750, foi eainda está se desenvolvendo a séric ISO 14000, da International Standardization Organization, sediada em Genebra, que pretende estabelecer padrōes para sistemas de gerenciamento ambiental (ISO 14001); auditoria ambiental (ISO 14010, 14011 e 14012); rotulagem ambiental (ISO 14020, 14021 e 14024); avaliação do ciclo de vida (ISO 14040) e aspectos ambientais em normats de produtos (ISO 14060)). No Brasil, o Instituto Nacional de Metrologia, Normalização e Qualidade Industrial (INMEIro) é o responsável pela aplicação, credenciamento e certificaçāo da série ISOs. Alualmente, só a ISO 14001 estí sendo operacionalizada em nosso país.

É interessante ressaltar que a preocupaçāo com o meio ambiente interno das indústrias decorreu do aumento da percepção dos riscos e impactos ambientais por parte dos consumidores, que passaram a preferir produtos gerados a partir de tecnologias menos agressoras ao meio ambiente.

\section{Situaçōes de Risco (Acidentes) e Política de Desenvolvimento}

Scjam de origem natural ou antropogêniça, os acidentes representam grande ameaça ao desenvolvimento sustentável. Recursos preciosos sāo perdidos em conseqüência do lato de que um desastre faz desaparecer os resultados dos investimentos. 
Freqüentemente as atividades dedicadas ao desenvolvimento são bloqueadas por causa de um desastre que assola determinada região, exigindo a reestruturação de investimentos plancjados a longo prazo.

Uma deficiente política de desenvolvimento costuma causar danos ao meio ambiente, que, por sua vez, pode provocar desastres de origem natural ou antropogênica, ou precipitar o surgimento deles.

Exemplos disso são as cidades superpovoadas que creseem às custas da destruiç̧io do meio ambiente, com bairros construídos nos leitos dos rios, o desflorestamento agravando as conseqüências das inundações e as avalanches de terra e lodo, ou os despejos não controlados que contaminam as águas.

Junto a isso, outros eventos recentes trouxeram à tona o assunto da prevenção, segurança e preparação das populações, cm todos os países do mundo, para situações de risco. Tais situações são geradas tanto pelo homem como pela natureza. Como exemplo de eventos importantes de origem natural ocorrido há pouco tempo, podemos citar: o terremoto que abalou a Cidade do México em 1985, os deslizamentos de terra no Equador em 1987, a liberação de vapores tóxicos de um lago na República dos Camarões e a erupção do vulcāo Pinatubo, nas Filipinas. Segundo o jornal El País, de Madri, em 1992 os desastres naturais foram responsáveis por mais de 150 mil montos e desaparecidos - a imensa maioria na Ásia -, e cerca de 23 milhões de pessoas licaram desabrigadas.

Dentre os eventos de origem antropogênica, os acidentes industriais incluem-se entre os que mais danos causaram à saúde ambiental e também os que mais perdas inaceitáveis de vidas e propriedades provocaram. Como exemplo, podemos destacar:

- a liberação de dioxina em Seveso, em 1976;

- a explosão de propano na Cidade do México, em 1984;

- a liberação de metil-isocianato em Bhopal, cm 1984;

- 0 incêndio e a descarga de águas contaminadas no rio Reno, em 1986.

É universalmente reconhecido que todo acidente, qualquer que seja sua causa, ocasiona impactos ao meio ambiente.

A ciência não alcançou ainda o estágio de poder explicar, prever ou efetivamente prevenir todas as causas de acidentes naturais. Todavia, existe a necessidade de uma preparação para o eletivo atendimento a essas situações de emergência quando e onde ocorrerem. No entanto, especialistas em segurança industrial defendem a idéia de que todos os acidentes tecnológicos podem ser prevenidos, mas são suficientemente realistas para reconhecer que deve haver uma preparação de planos preventivos de atendimento para tais circunstâncias.

Enquanto a maioria dos acidentes industriais pode ser controlada dentro dos limites da fábrica, há casos onde o impacto se estende para além de suas fronteiras, afelando os 
arredores da indústria e tendo conseqüências, a curto ou longo prazo, sobre a vida, propriedades, estrutura social e meio ambiente.

A extensão das perdas causadas por tais acidentes depende em grande parte das atitudes tomadas pelos primeiros interventores na situação de emergência dentro do complexo industrial e da comunidade ao seu redor. Com certeza, o atendimento adequado desses casos exige atitudes coordenadas de indivíduos e instituições da comunidade local. Isso só poderá ser conseguido se esses moradores estiverem conscientizados dos possíveis riscos $\mathrm{e}$ da necessidade de preparo mútuo para enfrentar as consequiências.

Aumentar o conhecimento da comunidade sobre possíveis riscos na área e desenvolver, com base nessa informação, planos de atendimento em situações de emergência, são as propostas fundamentais contidas no Manual de Alerta e Preparaçāo de Comunidades para Emergências Locais (APELL, 1990), preparado pelo Programa Ambiental das Nações Unidas (United Nation Environmental Proteccion - UNEP), sobre o processo de atendimento a acidentes tecnológicos.

Com relação à localização dos empreendimentos industriais, foi desenvolvido, após o acidente de Seveso, a diretiva que leva o mesmo nome, a qual classifica os empreendimentos quanto a seu grau de risco e quanto aos efeitos quando de emissōes acidentais.

No Brasil, esta diretiva foi adaptada às condições nacionais pela Companhia de Engenharia e Tecnologia de São Paulo (CETESB) e chama-se CATBRÁs (Awazu, 1990). É conhecida como a diretiva dos critérios de identificação e classificação do potencial de risco de acidentes ambientais das atividades industriais. Permite ao administrador público conhecer o grau de risco de uma indústria, em três níveis: alto, médio e baixo, facilitando assim a prioridade de ações de controle e o gerenciamento dos riscos.

\section{Instrumentos de Política de Saúde Ambiental}

Uma política de saúde ambiental requer instrumentos claros e eficazes. Vários sāo os instrumentos existentes:

- uma clara legislação ambiental e de saúde;

- caracterização e valoração ambiental;

- instrumentos de mercado;

- processo de Avaliação de Impacto Ambiental (AIA);

- processo de Avaliação de Risco Ambiental (ARA);

- uso e ocupação do solo;

- manejo de recursos ambientais; 
- planos de recuperação de áreas degradadas;

- educação ambiental.

A estrutura de política de saúde ambiental é ainda complementada pelas provisões para execução legal e multas para a proteção do meio ambiente. É também guiada pelo princípio da ação precatória, princípio do poluidor pagador e princípio da cooperação.

Um importante mecanismo de ação precatória de uma política ambiental diz respeito às ordens legais e às proibições formuladas por meio de leis administrativas. Há, contudo, um limite na efetividade dessas leis administrativas. Por exemplo, diretrizes e proibições não propiciam aos poluidores incentivo algum para manter a degradação ambiental, em níveis mínimos, usando conhecimentos científicos e progresso técnico. É essencial aumentar-se o uso de instrumentos que reforcem no poluidor o seu senso de responsabilidade, promovam seu próprio interesse na proteção ambiental e incorpore instrumentos de mercado, como por exemplo, os trade permits (negociação de quotas de poluição).

Dos instrumentos de política de saúde ambiental citados, somente os processos de Avaliação de Impacto Ambiental (AIA) e os processos de Avaliação de Risco Ambiental (ARA) serão discutidos aqui.

\section{AvaliaçÃo de ImPacto}

\section{HISTÓRICO}

Ao final da década de 60, nos países industrializados e também em alguns em desenvolvimento, o crescimento da conscientização do público, paralelamente a uma rápida degradação do meio ambiente e da saúde, levou a população a começar a se organizar, a reivindicar uma melhor qualidade ambiental e a exigir que os fatores ambientais fossem expressamente considerados pelos governos na aprovação de programas de investimento e em projetos de grande envergadura. Os métodos tradicionais de avaliação de projetos, baseados somente em critérios econômicos, mostraram-se inadequados para a tomada de decisão.

Na busca de meios que promovessem a incorporação dos fatores ambientais para essa tomada de decisão e também para a formulação de políticas especiais, surgiu uma série de mecanismos para a execução dessas políticas. Assim, procederam-se reformas administrativas e institucionais, criando-se incentivos econômicos para o controle da poluição; implantaram-se sistemas de gestão ambiental, abrindo-se os canais para que os cidadãos pudessẹm participar nas decisões.

Dos instrumentos gerados, os processos de Avaliação de Impacto Ambiental (AIA), consubstanciado por meio do Estudo de Impacto Ambiental (EIA), e de Avaliação de Risco Ambiental (ARA) foram desenvolvidos e rapidamente adaptados a diferentes esquemas institucionais. 


\section{Objeto e Complexidade dos Estudos de Impacto}

A degradação ambiental causada por uma ação ou atividade humana, como por exemplo os poluentes, introduz no meio ambiente substâncias ou energia passíveis de causar danos à saúde humana, aos recursos biológicos e sistemas ccológicos, ao patrimônio estético cultural $\mathrm{e}$ ao uso futuro dos recursos naturais.

Após sua emissão por uma fonte qualquer, os poluentes percorrem diversos caminhos, enı sua difusão no ambiente, até chegarem ao solo, ar e/ou água. Seu nível de concentração em cada ponto do percurso dependerá de diversos fatores, como a taxa de emissão, as característicals de sua dispersão (cm razão das propriedades do poluente e do meio) e a taxa de remoção do meio por agentes físicos, químicos e biológicos ao longo de todo o percurso. A interação entre um poluente c o meio receptor resulta em um efeito cuja naturcza, escala e importância, bein como a sua variação ao longo de tempo, serão o objeto central dos estudos de avaliação de impacto e risco.

\section{Processo de Avaliação de Impacto Ambiental (AIA) e Estudo de Impacto}

\section{Ambiental (EIA)}

O processo de Avaliação de Impacto Ambiental (AlA) é detinido como um conjunto de procedimentos realizados para identilicar, prever e interpretar, assim como prevenir as conseqüências ou cfeilos ambientais que determinadas ações, planos, programas ou projetos podem causar à saúde, ao bem-estar humano e ao entorno.

Tais projetos podem ser nas áreas de: agricultura, recursos naturais (irrigação, reflorestamento, desmatamento etc.), na indústria (refinarias de petróleo, cervejarias, químicas etc.) e em inlra-estrutura (estradas, barragens, portos, casas etc.). Podem gerar eleitos ambientais adversos - como resultado da sua localização inapropriada - de projetos e construçōes inadequadas, pessoal desqualificàdo e baixo nível de manutenção e operação, além de mal uso dos recursos naturais. Impactos negativos podem modificar a qualidade do solo e da água (perda da biodiversidade, erosão elc.), a qualidade do ar (smog, diminuição da cimada de ozônio, efeito estufa etc.), a paisagem, a saúde e o bem-estar humano.

O AIA consiste de vários componentes como: anúncio do projeto; primeira triagem; avaliaçāo ambiental preliminar; Termo de Referência (Term ol Reference - TOR); organização do projeto; ElA e Rıma (Relatório de Impacto Ambiental); monitoramento; avaliação e auditoria.

Como parte integrante do AIA, o EIA tem como principal objetivo o de propiciar subsídios para uma tomada de decisão. Propõc-se a identificar e descrever os impactos positivos c negativos oriundos dos projetos, além de sugerir medidas de proteção ambiental ou outros planos de gestão ambiental que incluem medidas de mitigação ou compensação para se reduzir os impactos negativos previstos e, ainda, indicar outras providências que permitam minorar os cleitos dos impactos. Uma sucinta descrição de cada componente do AIA é apresentada a seguruir: 
- Anúncio do projeto - notificação (anúncio) oticial, para todas as partes interessa das, da decisão de se realizar um projeto de desenvolvimento. Por exemplo, um sistema de transporte de carga para uma região, fontes alternativas de produção de energia elétrica etc...

- Primeira triagem - pode servir para identificar alternativas e seus impactos. Por exemplo a escolha entre o transporte de carga ferroviário e fluvial em detrimento do rodoviário. É também usado para se determinar quais projetos e/ou componentes destes, fora dos previamente propostos na fase de identificação, precisam de considerações ambientais extras.

- Avaliação ambiental preliminar - segunda fase da triagem para aqueles projetos ou componentes de projetos que apresentem desde o início uma clara indicação do potencial de impactos que requererão uma análise ambiental mais apurada. Esse estágio envolve identificação, descrição, predição e avaliação dos impactos ambientais potenciais.

- Escopo do projeto - inclui a preparação de todas as informações básicas sobre o projeto; notificação e envolvimento das partes interessadas (exceto o proponente/ executor e a agência reguladora) e a coleta de opiniões sobre as diversas alternativas e seus impactos potenciais; preparação do Termo de Referência (Term of Reference - TOR) para o Estudo de Impacto Ambiental (EIA).

- Organização - envolve a escolha do coordenador e do grupo responsável pelo estudo; identificação do tomador de decisão que deverá planejar, financiar e controlar o projeto; levantamento de toda a legislação e regulamentos que possam afetar as decisōes sobre o projeto e determinar como e quando as comunicaçōes sobre este serão efetuadas.

\section{Estudo de Impacto Ambiental (ElA) e Relatório de Impacto Ambiental}

\section{(RIMA)}

Identifica e prediz os prováveis impactos do projeto, propõe medidas mitigadoras para impactos inaceitáveis e, conjuntamente com esta, sugere as alternativas para posterior tomada de decisão. Deve envolver também a participação do público, por meio das audiências públicas. Após analisado e revisado pelo órgão decisório, o projeto é aprovado sem ressalvas, ou aprovado mediante condições ou, ainda, rejeitado.

Um resumo do EIA escrito e apresentado em uma linguagem e forma simples, mostrando os principais pontos e conclusões, denomina-se RıMA e deve ser entregue junto com este.

Em um EIA, diversas técnicas podem ser utilizadas para avaliação dos impactos, como consultas a especialistas, check-list, matriz de Leopold, método Battelle, superposição de 
mapas c modelos. Geralmente, um EIA é dividido nas seguintes etapas: descrição do sítio (sem o projelo); escolha e justificativas das variantes (alternativas); identificação dos impactos; avaliação dos impactos e proposição de medidas mitigadoras.

- Monitoramento - visa ao acompanhamento dos efeitos ambientais previsto no EIA para: analisar os impactos e comprovar a efetividade das medidas miligadoras sugeridas; servir de alerta para o controle de impactos não previstos ou de intensidade maior que o espera do no projeto.

- Avaliaçāo e auditoria - são normalmente executadas durante o período de operação do projeto, geralmente no meio ou no fïm de sua vida útil. As lições aprendidas neste período de avaliação são importantes para se evitar erros em projetos futuros. No caso do aparecimento de um problema ambiental proeminente, uma auditoria ambiental pode ser solicitada; esta constitui-se de um estudo especíílco dentro do processo de avaliação.

\section{Inserçāo da Componente Saúde nos ElAs de Projetos de}

\section{DESENVOLVIMENTO}

O retrospecto do desenvolvimento dos estudos de impactos mostra que, nos anos 70 , a maioria dos EIAs era realizada usando basicamente julgamentos baseados $\mathrm{cm}$ análises de custo-benefício. No final da referida década e começo dos anos 80 a componente social passou a ser plenamente incorporada nesses estudos. Recentemente, a partir do final dos anos 80 e começo dos anos 90 , diversos autores passaram a defender a inclusão dos estudos de saúde como parte integrante do EIA, conhecido em inglês como EHIA (Environmental Health Impact Assessment).

O objetivo do EIA é predizer e avaliar os impactos provocados pelo desenvolvimento baseado nos parâmetros ambientais que tenham uma forte interferência na saúde dos ecossistemas e principalmente na saúde humana. No caso de projetos de desenvolvimento, por exemplo, os impactos negativos para a saúde do homem podem ser determinados por intermédio dos estudos de Avaliação de Impacto na Saúde (Health Impact Assessment HIA). Tais estudos incorporam a identilicação do perigo à saúde, definido como o potencial que tem o projeto de causar danos às pessoas. Nesses projetos, o conceito de risco à saúdc é introduzido; é definido como a probabilidade de um efeito do projeto causar danos à saúde humana.

O HIA pode se tornar, cm alguns casos, parte central de um Estudo de Impacto Ambiental (EIA). Seu cscopo é similar ao de um EIA, contudo, a ênfase é centrada na consideração dos perigos à saúde e nos fatores como a vulnerabilidade da comunidade, condiçōes ambientais e condições do sistema de saúde existente. Um perigo para a saúde representa potencial para causar doença. Um risco para a saúde indica a probabilidade de que ela aconteça. Por exemplo, em Manila, nas Filipinas, a malária é um perigo para a 
saúde, mas não um risco, porque não existe no local a espécie de mosquito capaz de transmitir a doença (Asian Development Bank, 1992). De acordo com o Banco Africano de Desenvolvimento, os perigos à saúde associados aos projetos de desenvolvimento são geralmente divididos em quatro principais categorias:

\begin{tabular}{ll}
\hline & Exemplos \\
\hline - Doenças transmissíveis & Malária, diarréia, infecções respiratórías \\
- Doenças não-transmissíveis & Envenenamento, poluição, poeira \\
- Desnutrição & Redução na alimentação de subsistência \\
- Ferimentos & Acidentes de tráfego e ocupacional \\
\hline
\end{tabular}

O processo de avaliação de impacto na saúde ambiental, além de considerar a análise dos problemas de saúde em sua totalidade, deve classificar os perigos de acordo com a capacidade de aumentar ou diminuir a magnitude dos impactos resultantes das intervençôes causadas pelos projetos de desenvolvimento.

\section{Gestão, Análise e Avaliação de Risco na Saúde Ambiental}

\section{Conceitos de Gestão e Avaliação de Risco}

Para Hallenbeck (1986), Gestão do Risco trata-se de um processo que inclui seleção e implementação da ação regulatória mais apropriada, tomando por base os resultados do processo de Avaliação de Risco, do controle tecnológico disponível, da análise de custobenefício, do risco aceitável, do número aceitável de casos, da análise política e dos fatores sociais e políticos.

Importante instrumento de política ambiental, o processo de Avaliação de Risco (AR) começou a ser usado mais freqüentemente a partir dos anos 80 e é empregado em uma gama muito variada de problemas. Seu campo de aplicação abrange desde os efeitos da poluição ambiental nos seres humanos e nos ecossistemas até as decisões financeiras. Os diferentes enfoques utilizados para se efetuar uma Avaliação de Risco vão desde o estudo de uma propriedade química, física ou biológica de um determinado material, ou atividade, até o cálculo numérico de índices e a apresentação de informaçōes sobre probabilidades de ocorrência e conseqüências de eventos catastróficos.

A Avaliação de Risco é definida por Berger (1982) como a identificação do perigo, a localização de suas causas, a estimativa da extensão dos seus danos e a comparação destes com os benefícios. Para Canter (1989), a AR é um processo que inclui conjuntamente a análise do risco e a análise de segurança, em que a primeira é uma avaliação quantitativa das conseqüências das decisões, e a segunda, a avaliação do nível do risco aceitável para a sociedade. 
Conway (1982) define Avaliação de Risco Ambiental (ARA) como o processo de avaliação conjunta de dados científicos, sociais, econômicos e de fatores políticos que precisam ser considerados para a tomada de decisão sobre por exemplo a proibição, o controle ou a gestão de produtos ou atividades no meio ambiente; a decisão linal envolve a medição científica do risco e o julgamento social, no qual os benelícios dos produtos ou atividades são comparados ao risco.

\section{Histórico e Desenvolvimento dos Procedimentos de Avaliação e Gestāo}

\section{Do RIsco}

A Avaliação de Risco é uma caracterizaçĩo sistêmica e científica do potencial adverso dos efeitos das exposições humanas a agentes ou a atividades perigosas. Nos Estados Unidos esse processo iniciou-se nos anos 70, como uma atividade estruturada pelas agências federais. Anos antes, a Conferência Governamental Americana de Higienistas Industriais instituiu vários limites mínimos de exposição para trabalhadores, e a Agência de Alimentos e Drogas (Food and Drug Agency - FDA) estabeleceu os primeiros valores de doses accitáveis para ingestão de resíduos de pesticidas e aditivos usados em dietas alimentares. Em meados de 1970, a Agência Americana de Proteção Ambiental (Environmental Protection Agency - EPA), juntamente com a FDA, publicou os primeiros guias para se estimar os riscos associados com baixos níveis de exposição a químicos potencialmente carcinogênicos. Nesses guias foi proposto que açōes regulamentadoras deveriam ser iniciadas quando existisse o risco do aparecimento de um caso extra de câncer, considerando o período de vida de uma pessoa, em uma população de 100 mil pessoas, para o EPA, ou de um milhão, para o FDA. Os riscos estimados abaixo desses limites são considerados negligenciáveis, uma vez que acrescentam individualmente muito pouco à taxa de 240 mil mortes por câncer para cada milhāo de pessoas que morrem todos os anos nos EUA.

De 1977 a 1989, diversas organizações, entre as quais o EPA, a FDA, a Adıninistraçĩo de Segurança e Saúde Ocupacional c outros, participaram ativamente de atividades visando consolidar os conhecimentos científicos e as responsabilidades legais e administrativas dos órgãos, trabalhando com a questão da Avaliação de Risco. Nesse mesmo período, o Comitê de Política de Ciência e Tecnologia da Casa Branca publicou um esquema para identificação de riscos potenciais, caracterizaçăo e Gestão do Risco.

Nesse esquema, a redução das emissões e das exposições foi amplamente enfatizada (Calkins et al., 1980), indicando claramente também que as informações necessárias ao primeiro estágio do estudo de Avaliação de Risco poderiam ser obtidas por meio de estudos epidemiológicos com trabalhadores e outras pessoas sujeitas a exposiçōes potencialmente perigosas, a testes experimentais realizados com animais ou células em laboratórios, e da comparação das estruturas químicas. No segundo estágio, que envolve a medição da potência do agente químico (relação de dose-resposta), há a necessidade de se conhecer e entender detalhadamente as rotas de exposições e as causas relacionadas às variações ocorridas nas respostas das pessoas expostas. O risco deve ser caracterizado qualitativamente (natureza dos eleitos, força da evidencia, e reversibilidade ou previsibilidade dos efeitos) e quantitativamente (probabilidade dos efeitos de várias espécies e severidades). 
Até recentemente, porém, os procedimentos dos estudos de risco resultavam em uma abordagem fragmentada do risco, baseada em açōes conllituosas que ignoravam a interdependência dos componentes ambientais, que entatizavam as diferenças em vez das similaridades entre câncer e outros efeitos na saúde, e investigava os riscos associados com químicos individuais ao invés de misturas de químieos. Apesar de muitos anos de gerenciamento do risco ambiental e de acidentes, não existe até então un procedimento getal accito e uniformemente aplicado.

Encuanto muitas decisöes eficazes foram tomadats baseadas en estudos de gerenciamento de riscos, muitas outras deixaram insatisfejtos ou frustados os proponentes es interessados. Muitos destes têm reclamado que os estudos de risco precisam ser organizados de maneira que envolvam o estudos dos eleitos múltiplos das exposições e que o meio ambiente seja considerado como um sistema, não como uma fragmentada coleção de riscos individuais.

A integração efeliva da Gestão do Riseo ao gerenciamento ambiental requer uma estrulura que engaje um grande leque de interessados e que estude a interdependencia cos elcitos cumulativos dos vários problemas. Com esse intuito foi constituída em 1990, pelo Congresso norte-americano, uma Comissão de Gerenciamento e Avaliação de Riseo encatrregada de consolidar os diversos procedimentos existentes de Avaliação de Risco e de propor un nova estrutura de Gestão do Risco. O relatório loi recentemente publicado (Commission on Risk Assessment and Risk Management, 1996). Nele, a comissão propõe que o gerenciamento do risco lenhat a capacidade de abordar conjuntamente os vários compartimentos, os contaminantes, as fontes de exposiçöes e umat séric de valores e percepções humanats. Deve ser sufieientemente claro e compreensível, de modo que possa ser adotado e usado pelos gestores de risco em dilerentes situações e que possa fornecer subsídios para comada de decisões aceitáveis. Deve também ser tlexível, para que o seu uso possá ser adaptado à importância da decisão a ser tomada.

Entre os principats objetivos dessit comissão encontra-se o de também ter lormulado um procedimento de gerenciamento integrato de risco que losse além do clássico controle ambiental bascado nas técnicas do end-of-pipe, e que inclusse os mecanismos que lossem capazes de proporcionar um desenvolvimento sustentável. Tal procedimento, obviamente, requer o seguinte: conhecinento e entendimento das interaçóses existentes na saúde ambiental, nal qualidate de vida humana, e também a compreensão dos processos pelos quais nossal sociedade cria mudinf̧ás a longo prào, sejam estats benéfieals ou adversals.

Un resumo dos procedimentos de gerenciamento integraldo do risco, proposto pela comissão, é apresentado e comentado a seguir. Eie é dividido em seis partes, interligadas à colaboração do(s) proponente(s) (stakeholder(s) ou interessados(s):

\section{- Primeira Parte: Problema/Contexto}

Qua! a definição do problema. de seu contexto? Quem se responsabiliza por sua gestĩo? Quem sĩo os interessados; ou: quem são os proponentes do estudo? Nesse primeiro momento, o problema existente ou potencial pode ser jdentilicado utilizando-se, por exemplo, vários procedimentos: monitoramento ambiental; inventário das emissōes; controle de 
doenças e observações epidemiológicas; doenças inexplicáveis; maus odores; necessidade do estabelecimento de padrões nacionais para o controle de contaminantes no ar, água, solo ou alimentos; ou outro problema de interesse público.

O problema deveria ser examinado não somente num contexto compartimentopoluente, mas em um multicompartimental que envolva as relações sociais e de saúde. Relaçōes potenciais entre os diferentes problemas devem ser identificados e considerados. Por exemplo, a degradação de um ecossistema aquático pode ser causada não somente por fontes pontuais de despejos de efluentes mas também por fontes difusas, como os poluentes provenientes do run-off urbano ou agrícola. Ele pode também ser afetado pelos distúrbios provocados por atividades de retirada de madeiras, construção de represas, desvio de rios, modificações dos lençóis subterrâneos, pesca em excesso, introdução de espécies exóticas etc. A deposição de poluentes oriundos da atmosfera como nitrogênio, chumbo, cádmio, cromo, mercúrio e radionuclídeos provavelmente também contribuem para o problema.

É necessário que os proponentes sejam intensamente envolvidos com a identificação e caracterizaçăo do problema e do seu contexto. Os gestores de risco podem ser pessoas ou instiluições nos níveis federais, estaduais ou municipais, dependendo da composição do problema. Os objetivos do programa de Gestāo do Risco deveriam ser definidos quando uma apreciaçāo coletiva na caracterização do problema tiver sido alcançada.

Os contextos apropriados para um problema são como se fossem situacionais, porque, em alguns casos, um deles pode ser toda a saúde pública. Em outros, pode ser os demais riscos. Pode ainda, em outros casos mais, ser a relação de interdependência de diferentes problemas (como a degradação do ecossistema aquático descrito anteriormente).

\section{- Segunda PARTE: RISCOS}

O segundo passo envolve a identificação do(s) risco(s) que o problema identificado pode causar para a saúde pública. Ele(s) pode $(\mathrm{m})$ ser determinado(s) considerando-se a natureza, o comportamento e a severidade dos efeitos adversos para a saúde humana, o meio ambiente ou a qualidade de vida (como o bem-estar econômico ou os valores estéticos). Deveria(m) ser avaliados primariamente por cientistas e gestores de risco, com a ajuda dos interessados (proponentes), de modo que aqueles pertencentes à comunidade deveriam ser contatados nesta fase para ajudar a identificar os grupos sujeitos a maiores taxas de exposições. As evidências e os dados científicos do problema poderiam ser articulados e incorporados, juntamente com as percepções do caso, para a caracterização do risco para o humano e o meio ambiente. Considerações de ordem cultural e valores sociais, qualidade de vida e eqüidade ambiental deveriam também ser levadas em conta.

Os riscos para a saúde humana e para os ecossistemas deveriam ser tratados, ambos, qualitativamente e quantitativamente. A natureza dos efeitos adversos, suas severidades, suas reversibilidades ou previsões, e a possibilidade de efeitos múltiplos precisam ser 
compreendidas antes que uma estimativa complexa da magnitude dos riscos e de suas incertezas sejam apresentadas. Os riscos cumulativos associados com o problema deveriam ser identificados sempre que possível. Os efeitos indiretos na saúde humana provocados a partir dos impactos no meio ambiente deveriam também ser considerados.

\section{- Terceira Parte: Opções}

Acerca do problema, o que pode e deve ser feito? Quais as conseqüências potenciais e os benefícios esperados pela intervenção? Existem outras maneiras para se reduzirem os efeitos similares na saúde dessa mesma população e/ou os efeitos ecológicos? Quais os custos estimados para cada opção? As diferentes maneiras de se abordar tais questôes deveriam ser identificadas pelos interessados (proponentes), legisladores e cientistas. $O$ uso de uma série de alternativas regulamentadoras e não-regulamentadoras deveria ser considerada, como licenças, restringir açōes, prevenir a poluição, reciclagem, incentivos de mercado, reduçōes voluntárias e educação. A possibilidade do uso de instrumentos institucionais, financeiros e outros tipos de arranjos para a implementação de cada procedimento deveria também ser identificado. A redução do risco esperado e a relação entre o custo e o benefício de cada solução precisaria ser determinado e comparado. Dimensões culturais, éticas, políticas e legais deveriam ser levadas em consideração. Os impactos potenciais de cada procedimento necessitariam ser caracterizados, incluindo os efeitos adversos nos trabalhadores, na comunidade ou no meio ambiente.

\section{- Quarta Parte: Decisäo}

Qual a melhor solução para o problema? Como uma decisão ou um leque delas pode ser alcançada(o)? Quem as deve tomar? Serão elas compatíveis com a legislação existente? O procedimento a ser identificado para mitigar o problema deveria ser o mais eficiente, aceitável, e com a melhor relação custo-efeito, incluindo a participação das partes proponentes e das partes afetadas. Um mecanismo para a solução de conflitos, ou para o alcance do entendimento na ausência de consenso, poderia ser útil. É importante reconhecer que o procedimento proposto não resultará sempre em consenso entre os envolvidos no processo. De fato, participação, negociação e tentativa de compromisso pode resultar, algumas vezes, em endurecimento de posiçōes antagônicas, em interrupção nas negociações, em frustrações com o processo, e em inabilidade para se alcançar um acordo. Tais dificuldades para se alcançar uma decisão não devem ser vistas como uma falha do processo, mas simplesmente como um reconhecimento de que em certas circunstâncias, apesar dos melhores esforços de todas as partes envolvidas, o consenso não será alcançado. Em algum ponto, a autoridade reguladora precisará tomar sua decisão, incluindo a de discordar, se a oposição for muito forte ou bastante credível. Divergir pode requerer uma decisão posterior de se repetir, ou não, o processo desde o começo, ou prosseguir e atacar outros problemas mais prementes. 


\section{- Quinta Parte: Açóes}

De que maneira uma decisão pode ser rapidamente implementada e conn que flexibilidade? A ação que tiver sido escolhidal para atacar o problema deve ser explicadal e implementadlat. Várias açōes podem ser necessárias em dilerentes circunstâncias. Devem ser tomadas por agências públicas, de comércio, indústrias e por cidadãos privados, sozinhos ou não. Objeções ou reavaliações, mesmo neste estágio, podem influir no processo de interaçă̄o.

\section{- Sexta Parte: Avaliação}

Qual a extensão da eficácia das ações? Freqüentemente são executadas, mas existe um pequeno acompanhamento para se assegurar de que realmente são implementadas, para se analisar eticácia e custo ou para comparar os resultados obtidos com os previstos no processo de tomada de decisão. $O(s)$ eleito(s) da açăo escolhida pode(m) ser caracterizado(s) por meio do monitoramento e da vigilância, por intermédio da discussão com os contratantes e mediante a análise das relaçōes entre as intervençōes e os problemas na saúde ou, ainda, por indicadores ambientais. Neste último caso, os critérios devem ser explicitados desde o início do projeto. Tal processo de avaliação permite que o problema original possa ser redefinido, as açōes reconsideradas e os vários estágios repetidos, se apropriados.

Se a avaliação dos impactos das ações propostas para resolver um problema concluir que elas não são satisfatórias, uma outra interação do processo pode ser necessária. Devemos considerar, contudo, que poucos efeitos e seus riscos podem ser facilmente medidos e confirmados. Até certo ponto, as técnicas de monitoramento e de vigilância podem ser capazes de estudar as relações entre as ações e seus efeitos, mas quase sempre essas relações são detectadas somente quando a margem entre as exposiçōes atuais e as associadas com os efeitos nocivos à saúde ou aos ecossistemas é reduzido, ou quando o efeito nocivo à saúde ć particularmente raro. A maioria dos riscos relacionados à saúde pública é muito pequena quando comparada aros riscos medidos a partir dos efeitos de acidentes ocupacionais ou de colisêes de veículos. Por exemplo, suponhamos que uma ação seja capaz de diminuir o risco ineremental de uma pessoa desenvolver um câncer (durante seu periodo de vida), a partir de uma exposiçāo particular de $1 \mathrm{em} 10$ mil para de $1 \mathrm{em} !$ milhão. Nenhum estudo de saúde ou atividade de vigilância poderia ser projetado para medir a efícácia de uma ação com tão pequena mudança, pois o câncer poderia ser a causa de morte de $24 \%$ da população em cada evento. Conclusões sobre quão eletiva foi uma ação nessas condiçōes teriam de se apoiar no monitoramento ambiental, nas mudanças registradas por marcadores biológicos de exposiçcões ou em outra mediçāo indireta do impacto na incidência da doença.

Um ponto bastante enfatizado na proposta da comissão de risco foi a necessidade de se incluir em cada estágio do estudo de risco as partes interessadas e os proponentes. Tal participação pode lacilitar a troca de informaçōes e idćias necessárias a todas as partes, quando da comunicaçāo das medidas necessárias a se tomar, para a redução dos riscos. 
O procedimento aqui mostrado não pretende que todas as suas etapas tenham que necessariamente ser aplicadas em um projeto de Gestão do Risco para uma tomada de decisão. Contudo, é um guia útil que deve ser aplicado de acordo com a magnitude e complexidade de cada problema. Cada nível de tomada de decisão irá requerer diferentes etapas de análises dos problemas.

A realizaçăo de um estudo completo de Avaliação de Risco é tarefa considerível, requer dados, conhecimentos técnicos e uma revisão bibliográfica intensiva. A decisão de se prosseguir com tal estudo é uma decisão de Gestão do Risco que leva em consideração a importância do probiema, com relação às questões científicas e aos impactos oriundos dos atos regulamentadores.

O campo de aplicação dos estudos de avaliação e dos programas de Gestão do Risco aborda hoje as mais variadas dificuldades e, como tal, está sujeito a intensas discussões. Entre os temas mais debatidos podemos citar: a avaliação da toxicidade e sua importância para os humanos, a suscetibilidade e as variações das exposições entre as populações, a descrição das incertezas, a avaliação dos efeitos oriundos das misturas de químicos, a realização de estudos de Avaliação de Risco Ecológico e a avaliação dos riscos associados, como as radiações e os microorganismos.

\section{O Modelo Geral do Risco}

Na Figura 2, apresenta-se o que chamamos pienamente Modelo Geral do Risco. Tratase de importante ferramenta para os estudos de Gestão do Risco. Com este modelo podemos facilmente estruturar a análise de muitos tipos de risco. Ele começa com o termo Fonte, que é de onde se origina uma Emissão de algo indesejável (massa e/ou energia). Normalmente se consideram as Fontes como tendo duas origens. Para o risco de segurança (safety risk), nos quais a exposição se dá sob alta intensidade e em um tempo curto, as Fontes são normalmente os desastres. Estes, normalmente, são eventos súbitos e abruptos nos quais uma grande quantidade de material e/ou energia é rapidamente expelido.

Acidentes envolvendo emissões súbitas e massivas são quase sempre releridos pelo termo 'perda de confinamento' (loss of containment), que, quando envolvida com materiais intlamáveis, pode causar eventos catastróficos. Incêndios e explosões de grande porte podem acontecer, provocando radiaçōes térmicas intensas e/ou sob pressões destrutivas. Quando materiais tóxicos estão implicados, imensas nuvens carregadas deles podem ser formadas e, levadas pelos ventos, podem atingir áreas muito populosas.

Em contraste com as Fontes resultantes de Acidentes, outras podem ser relacionadas com as atividades normais. Tais atividades incluem não somente a de manufatura industrial, mas também a do tráfego rodoviário, da agricultura, da produção de eletricidade etc. Comparadas aos Acidentes, as taxas de emissões associadas com Atividades são baixas. Um importante fator é que tais Fontes têm uma tendência a produzir Emissōes mais ou menos continuadas. Por essa razão, nonmalmente as ocorrências provenientes dessas atividades tendem a produzir menores intensidades (concentraçōes) do que as provenientes de acidentes, embora a ocorrência destes últimos seja mais rara. 
FIGURA 2 - O Modelo Geral do Risco

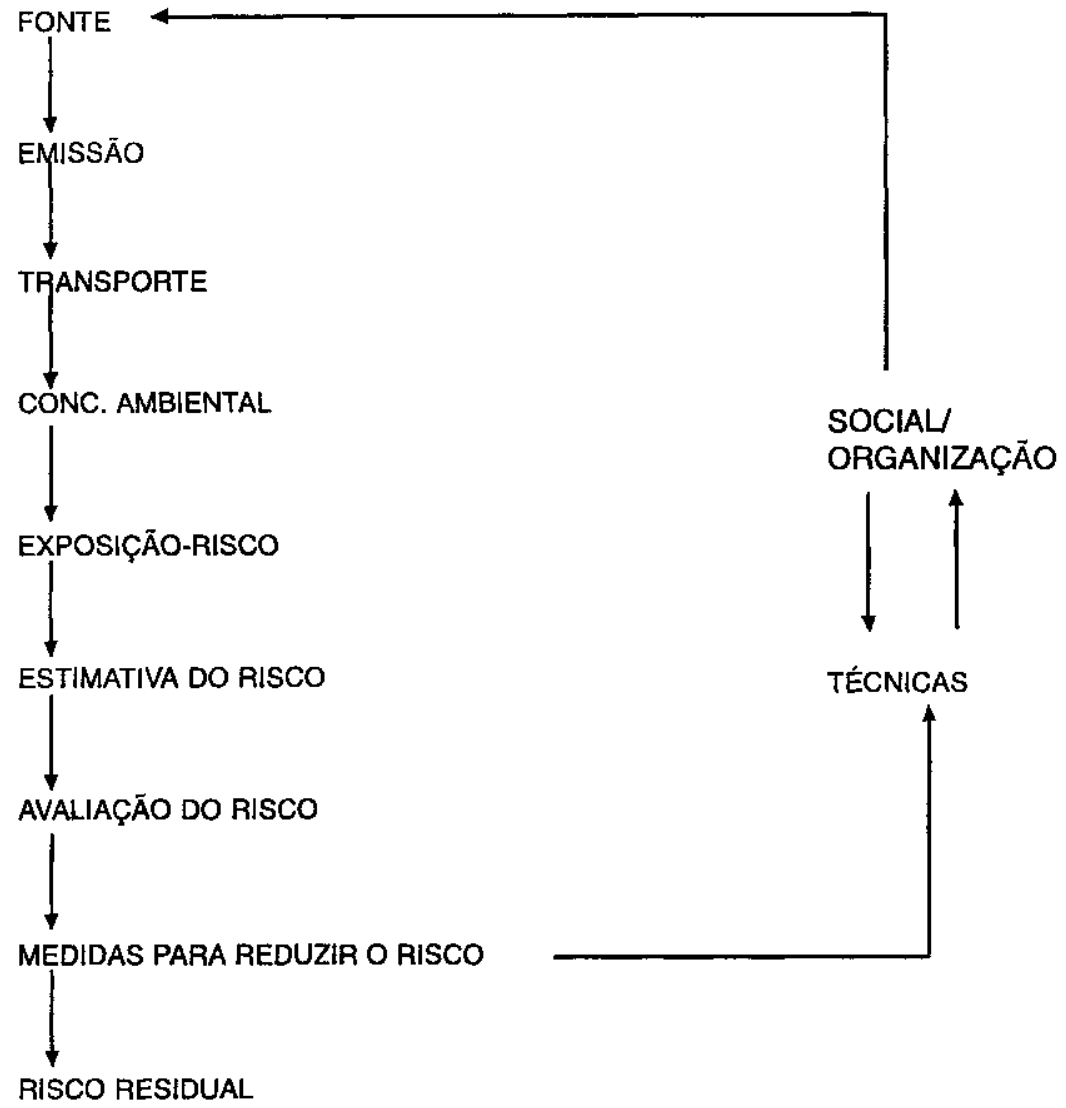

FONTE: BIBO \& LEMKOWITZ (1994).

As Fontes provenientes das atividades tendem a estar mais estreitamente associadas com os riscos relacionados à saúde e ao meio ambiente do que com os riscos relacionados a acidentes (segurança). Outros tipos de Fontes possíveis são: pontuais (chaminés), Fontes de linhas (auto-estradas) ou Fontes de área (complexos petroquímicos, cidades). As Fontes contínuas são geralmente encontradas associadas aos problemas de poluição do ar. Emissões contínuas de materiais tóxicos ou energia (ruídos) são comuns em ambientes ocupacionais. 
Não importando causa ou origem, as Fontes produzem Emissões de substâncias e/ou formas de energia que provocam efeitos adversos. As Emissões ocorrem em um ou mais compartimentos ambientais - ar, água ou solo -, que, por sua vez, estão em contato entre si, interagindo.

Uma vez que as Emissões de poluentes para o ar tenham ocorrido, procede-se a Transmissão (Transporte). Os modelos de Transporte tentam estimar a intensidade $c$ a duração da exposição, resultante da emissão para o ar, água ou solo, em razão de um certo número de parâmetros da emissão. Estes incluem: taxa e tamanho da exposiçăo; forma da fonte (pontual, linha, área); posição da fonte (para o ar: altura acima do solo); para a emissão de matéria: se gás/vapor ou aerossol (líquido ou sólido), tamanho e densidade das partículas; distância entre a fonte emissora e os alvos; para o ar: condições de clima (velocidade e direção dos ventos, estabilidade atmosférica); condições da topologia (plana, montanhosa etc.); para o solo: composição química e reações entre a atmosfera e os poluentes; e outros.

$O$ Transporte, aqui, significa movimento e quase sempre ocorre simultaneamente aos processos de Mistura e Diluição, algumas vezes com reações químicas. Por meio disso, as concentrações dos poluentes decrescem com o aumento da distância das fontes emissoras e o nível das concentraçōes ambientais (emission) se reduz. Como regra, nível de concentração ambiental signitica concentrações existentes nos lugares onde os alvos de estudo se encontram: seres humanos, plantas, animais, entre outros. Para o estudo do risco causado pela poluição do ar, os níveis das concentrações ambientais considerados são os medidos ao nível do solo. Denomina-se exposição o contato de pessoas, plantas ou animais com os agentes indesejáveis. Além de poder ser expressa como intensidade e duração, pode, ainda, resultar em risco.

A magnitude da ocorrência do risco não depende somente do grau da exposição, mas obviamente também do tamanho da população-alvo exposta. Tal fator pode, por excmplo, se referir ao número de pessoas expostas (estimado em termos de áreas de exposição e densidade de população), ao número de espécies raras expostas etc.

Uma vez que todas as etapas mostradas na Figura 2 tenham sido calculadas ou realisticamente estimadas, deve-se proceder a Estimativa do Risco. A palavra 'estimativa', e não 'cálculo', é conscientemente usada, muito embora um grande número de procedimentos matemáticos sejam utilizados. A ênfase também se justifica pelo grande número de incertezas e lacunas existentes no processo. Valores exatos e precisos para vários fatores usados nesses cálculos são usualmente difíceis, se não impossíveis de serem obtidos.

Além da Estimativa do Risco, há a necessidade de se proceder uma Avaliação do Risco. O processo de avaliação geralmente se refere a determinar se o risco é ou não aceitável. Obviamente, tal processo envolve julgamentos éticos. Estes, normalmente são baseados em considerações normativas (valores, crendices etc.) e, portanto, envolvem fa:ores e conhecimentos que vão além da ciência física e da engenharia. Eventualmente, decisões de política ou normas são propostas com base nos resultados desses estudos, no qual as questões econômicas são também muito importantes. 
Se um risco residual é julgado como aceitável, não haverá necessidade de se rẹuerer outras medidas, se não é, medidas extras são necessárias. Essas medidas, de mancira geral, podem ser dividas em duas categorias: de ordem social e de ordem técnica. Exemplos da primeira incluem mudanças nas leis, nos padröes, acordo entre o governo e as indústrias (convenants) etc. Tais medidas são quase sempre resultantes das mudanças de atitudes e de percepções.

\section{ANÁLISE DE RISCO}

Una análise de risco consitui-se um importante instrumento para se identificar riscos em uma unidade produtora ou em uma determinada atividade. É menos completa do que um estudo de Avaliação de Risco e ć usada normalmente para a identificação de riscos nas diferentes unidades de produção, permitindo a elaboração de mapas de risco do meio ambiente interno e externo. Enquanto o risco é calculado utilizando-se modelos para toxicidade, emissões líquidas ou gasosas, dispersāo, incêndios e explosões, os efcitos são calculados em razão da distância do ponto de ocorrência.

O estudo de Avaliação de Risco é recomendado para as grandes instalações em geral e para as indústrias químicas e de energia que lidan com materiais tóxicos e reativos, classificados peła Organização Mundial da Saúde (OMS) como produtos de toxicidade aguda c muito tóxicass, e que também apresentam alta probabilidade de risco de incêndios e explosões.

$\mathrm{Na}$ realização de uma análise de risco é importante se aplicar um procedimento estruturado. No início do estudo devem-se utitizar técnicas apropriadas e simples com a finalidade de identificar os riscos mais sérios para, em seguida, aplicar técnicas mais sofisticadas para avaliar a redução dos riscos. O procedimento básico para uma análise de risco inclui:

- identilicação das falhas potenciais;

- cálculo da quantidade de material emitido quando ocorre uma falha;

- cálculo do impacto de cada emissão nos equipamentos da indústria, nas pessoas, no meio ambiente e na propriedade.

Esse procedimento pode ser aplicado para toda uma indústria ou para parte dela.

Quanto aos principais passos para uma análise de riseo, de acordo com o World Bank (1990), são os seguintes:

- dividir o sítio $\mathrm{cm}$ unidades funcionais;

- dividir as unidades funcionais em componentes;

- fazer um inventário das matérias perigosas para cada componente; 
- classificar os componentes de acordo com o inventário;

- encontrar casos de falhas representativas para os componentes;

- agrupar os casos de emissões semelhantes;

- calcular a taxa das emissões;

- agrupar as emissões por taxas;

- calcular as consequêencias; apresentar os resultados;

- plotar o mapa dos efeitos versus distâncias;

- estimar as freqüências dos eventos;

- interpretar os resultados;

- escolher e analisar as ações de remediações.

Quanto à aplicação de uma análise de risco, podemos dizer:

Ela somente pode ser aplicada em algumas partes de uma indústria, como, por exemplo, naquelas que potencialmente possam causar danos severos ao ambiente interno ou externo do sítio onde estcja localizada. Nesse caso, uma lista de medidas destinadas a reduzir os efeitos versus distâncias deve ser executada. O responsável pela análise pode ainda repetir esses mesmos cálculos estimando agora os benelícios oriundos das medidas propostas.

Quanto à redução dos riscos, pode-se afirmar que:

Tanto cla como suas consequêencias envolvem, muitas vezes, profundas mudançils no projeto da unidade produtiva. Assim, uma análise de risco seria mais efetiva se realizada durante a fase de projeto da unidade, quando mudanças no próprio projeto, no lay-out $\mathrm{e}$ moditicações no sítio podem ainda facilmente ser feitas. De qualquer maneira, mesmo una análise de risco efetuada em uma unidade já em operação ainda mostrará oportunidades para se reduzir as conseqüências do risco.

Entre as diversas possibilidades de redução das conseqüências do risco, podemos citar: a redução do número de inventários, a modilicação do processo e das condiçôes de estocagem do material perigoso, a eliminaçẵo do material perigoso e a melhora do acondicionamento secundário. 


\section{AvalIAÇÃo de RISCO: TÉCNICAS E MÉTOdOS UTILIZADOS NAS SUAS DIVERSAS FASES}

Normalmente, o processo clássico de Avaliação de Risco é dividido em quatro partes:

- identificação do perigo (risco);

- avaliação da dose-resposta;

- avaliação da exposição;

- caracterização do risco.

Sobre este assunto, o leitor encontrará maiores detalhes nos capítulos 2 e 4 deste livro.

A seguir mostraremos as principais técnicas e métodos utilizados nas diferentes fases de um estudo de Avaliação de Risco Humano ou Ambiental.

\section{FASE 1: IDENTIFICAÇÃO DO RISCO}

A informação básica para a identificação do risco inclui dados epidemiológicos, dados de bioensaios com animais, dados de efeitos obtidos in vitro e comparações de estruturas moleculares. Estudos epidemiológicos bem conduzidos que mostram uma associação positiva entre um agente e uma doença são as evidências mais convincentes de risco para a saúde humana. Essa evidência, contudo, não é fácil de se obter. O risco quase sempre é baixo, o número de pessoas expostas é reduzido, o período de latência entre a exposição e a doença é longo, as exposições são misturadas a outras exposições e podem ser múltiplas.

Os dados mais comuns obtidos para a identificação do risco provêm de bioensaios com animais. A inferência de que esses resultados são aplicáveis ao homem é fundamental para a pesquisa toxicológica. Tal premissa convive com a maioria dos experimentos biológicos e médicos e logicamente é estendida para as observações experimentais de efeitos carcinogênicos.

Várias trabalhos experimentais mostram evidências de que a maioria dos produtos químicos carcinogênicos são mutagênicos e que muitos destes são carcinogênicos. Como resultado, uma resposta positiva em um ensaio de mutagenicidade (bactéria, células mamárias cultivadas) é uma evidência suportadora de que o agente testado é provavelmente um cancerígeno. Tais dados, na ausência de bioensaios positivos com animais, são raramente utilizados. Porém, como se constituem em testes rápidos e baratos, são usados como screening para a avaliação de potenciais efeitos da carcinogenicidade de químicos, fornecendo informaçōes adicionais para os estudos de bioensaios com animais e para os estudos epidemiológicos.

A comparação entre as propriedades químicas ou físicas de um carcinogênico conhecido, com a de um agente estudado, também fornece indicações sobre o potencial carcinogênico desses agentes. 
Um outro método a que se recorre bastante, na coleta de dados para a identificação do risco, é o uso do estudo de caso de clusters. Consiste simplesmente em se anotar o número de casos de uma doença rara, ou uma concentração anormal de doenças comuns, e tentar se encontrar a possível causa. Para se inferir esta e para examinar as possibilidades relevantes, conta-se com a intuição.

A caracterização das fontes de riscos é um importante passo na fase de identificação do risco. Diversas técnicas podem ser utilizadas: árvores de eventos ou árvores de falhas que permitem identificar os impactos de interesses potenciais; modelos matemáticos que podem ser utilizados para caracterizar o transporte $e$ as transformações de poluentes particulares; o desenvolvimento e uso de técnicas de ranking (classificação), úteis para propiciar comparaçôes relativas sobre o potencial do risco.

\section{FASE 2: DOSE-RESPOSTA}

Em poucos casos os dados epidemiológicos permitem que uma relação dose-resposta possa ser desenvolvida diretamente a partir das observações das exposições e dos efeitos na saúde humana. Por não haver muitos dados disponíveis sobre a carcinogenicidade humana - como por exemplo, dos produtos químicos -, para obtê-los, normalmente os estudos de dose-resposta se utilizam dos testes em animais como ratos e camundongos. Vale ressaltar que os referidos testes são tipicamente característicos da fase de identificação do risco, não da determinação de relaçōes de dose-resposta. Na prática corrente atual esse tipo de ensaio é feito da seguinte forma: um determinado grupo de animais recebe do agente testado a mais alta dose a ser tolerada; um segundo grupo é exposto à metade desta dose, e um outro grupo, chamado de controle, não é expostó (Canter, 1989).

$\mathrm{O}$ teste de produtos químicos empregando elevadas doses tem sido contestado por vários cientistas, que argumentam, entre outras coisas, que o metabolismo dos químicos difere quando expostos a altas e baixas doses. Doses elevadas podem provocar reações anormais no mecanismo de desintoxicação e estimular resultados que não ocorreriam se expostos a doses baixas.

Os reguladores estão interessados em doses nas quais os seres humanos facilmente poderiam vir a estar expostos e que normalmente são bem menores do que as administradas nos testes com animais. Por esse motivo, a partir do estudo de avaliação de dose-resposta, quase sempre é necessário se extrapolar uma curva de exposição esperada sobre uma gama de doses aplicadas usando-se um ou dois dados pontuais atualizados (National Research Council, 1986). E para extrapolar esses dados de laboratório para doses menores pode-se fazer uso de vários modelos matemáticos. Estes, são usados para predizer os riscos que os seres humanos estariam sujeitos quando expostos a pequenas doses.

Quando se extrapolam dados de animais para humanos, as doses usadas nos bioensaios precisam ser ajustadas para permitir que se considerem as diferenças de tamanho e das taxas de metabolismo. Tal tipo de teste tem levantado uma série de discussões e aponta a existência de um grande número de incertezas. 
Um estudo de avaliaçīo de dose-resposta não deve se limitar apenas aos efeitos ligados à saúde humana, mas ser estudado conjuntamente com os efeitos ambientais (ecológicos). Ao passo que certos estudos de Avaliação de Risco focalizam alguns aspectos ambientais, como danos à agricultura ou distúrbios em ecossistemas, a maioria se concentra nos efeitos à saúde humana tais como câncer, modificaçōes genéticas e mudanças neurológicas.

\section{FASE 3: EXPOSIÇÃO}

A avaliação da exposição envolve a determinação da concentração de agentes aos quais os seres humanos ou os ecossistemas estão expostos. Isto envolve o estudo dos processos de transporle e de transformação que esses agentes sofrem no meio ambiente. São vários os modelos para tal tipo de estudo.

Um importante aspecto da avaliação da exposição é a determinação do grupo, entre a população total, que está sendo exposto a um ou a alguns agentes. Certos grupos podem ser especialmente suscetíveis a efeitos adversos de saúde, como mulheres grávidas, criançass, pessoas idosas e pessoas com determinados tipos de problemas de saúde.

A importância da exposição a uma mistura de poluentes é também um fator que devese levar em consideração. Normalmente os dados sobre esse tipo de sinergismo são escassos. Por isso existe uma tendência a não considerá-los nos estudos. Nesta fase há também um grande número de incertezas que devem ser levadas em conta.

\section{FAse 4: CARACTERIZAÇÄO E AVALIAÇÃo do RISCO}

A caracterização do risco se relere à estimativa da magnitude do problema de saúde. O exercício de julgamento na escolha dos grupos de populações com variadas sensibilidades e diferentes exposiçōes pode afetar essa estimativa.

A avaliação tinal do risco é talvez a parte mais importante e delicada do processo de avaliação. Envolve também, algumas vezes, a necessidade de se comunicar os resultados obtidos a um público diverso. Procedimentos sistemáticos de tomada de decisão devem ser utilizados nessa parte do processo.

A Avaliação de Risco pode ser percebida como um processo de medição da significação do risco no contexto em que o mesino acontece. Tal objetivo envolve não somente o julgamento social do risco cstimado, mas a comparaçāo deste com o risco percebido e/ou os ganhos sociais estimados.

Nesse tipo de análise, três métodos podem ser utilizados para se julgar a aceitabilidade de um determinado risco: análise contextual, análise de preferência do público e análise de eqüidade (Sors, 1982). A seguir, discriminaremos cada um deles: 
Envolve a comparação do risco em questão com um ou mais aspectos: outro risco níveis naturais, riscos alternativos e outros não diretamente relacionados; comparação com os benefícios de um produto ou de uma atividade (análise de custo-benefício); comparação com os custos de redução do risco (redução custo/ efetividade).

- Análise de preferência do público

Envolve a comparação do risco percebido de acordo com os seguintes critérios: comparação com produtos existentes e aceitos, ou com atividades possuindo um benefício similar (preferências reveladas), e o que as pessoas dizem acerca da aceitabilidade do risco (preferências expressas). Alguns destes pontos são abordados no capítulo 3.

- Análise de eqüidade

Procura analisar as ineqüidades existentes na distribuição do risco, custos e benefícios relacionados com diferentes grupos sociais, diferentes regiōes e gerações.

\section{Bases Conceituais para Entender e Avaliar Saúde Ambiental}

Em nossas atividades diárias, cada qual convive com poluentes, seja respirando, bebendo água, consumindo alimentos ou entrando em contato com solos e poeiras. Esse contato, denominado 'exposição', requer a ocorrência simultânea de dois eventos: a presença de um poluente em um compartimento ambiental (água, ar, solo, alimento) e o contato entre a pessoa e um ou mais desses compartimentos. Exposição ambiental é definida então como o contato entre a fronteira externa do corpo humano (pele, nariz e garganta) e um poluente ou uma mistura deles. É quantificada por meio do cálculo da concentração do poluente e do tempo de contato.

São quatro as características que descrevem a exposição:

- Rota - ocorre por intermédio da inalação ou da absorção dérmica?;

- Magnitude - qual a concentração do poluente (ppm, ppb etc.)?;

- Duração - qual a duração (minutos, horas, dias, por toda a vida)?;

- Freqüência - com que frequiência ela ocorre (diariamente, semanalmente, sazonalmente etc.)'?

A exposição é um elemento-chave na cadeia de eventos que leva ao aparecimento de efeitos na saúde (Sexton et al., 1992). Mostrada na Figura 3, tal cadeia serve como base conceitual para o entendimento e avaliação da saúde ambiental.

Açōes tomadas pela sociedade para proteger seus membros de conseqüências prejudiciais da poluição são estabelecidas ou postuladas considerando-se as relações das fontes de poluição com a exposição humana e os efeitos adversos na saúde. 
A estimação do risco à saúde, associado como poluentes ambientais, é composto por duas atividades primárias: avaliação da exposição e avaliação dos efeitos. Durante a primeira, fase inicial da cadeia de eventos mostrada na Figura 3, avaliam-se: a(s) fonte(s) de emissão(ōes), as concentrações nos diversos compartimentos ambientais, os níveis de exposição e a dose. $O$ objetivo maior nessa fase é estimar o(s) nivel(eis) e o número de pessoas expostas. Adicionalmente, determinam-se as contribuições relativas de todas as fontes importantes e as rotas de exposição associadas à dose-alvo.

A avaliação dos efeitos na saúde, última fase da cadeia de eventos da Figura 3, inclui a avaliação da exposição, da dose e dos efeitos adversos. São dois os objetivos: determinação dos perigos intrínsecos à saúde associados com poluentes, incluindo os efeitos cancerígenos e não-cancerígenos; e a quantificação da relação entre a dose-alvo ou exposição e efeitos à saúde (por exemplo, dose-resposta) em populações humanas.

A sobreposição entre avaliação da exposição (Fase l) e a avaliação dos efeitos (Fase 2), também mostrada na Figura 3, reflete a importância da informação sobre exposição e sobre a dose para ambas as atividades. A determinação da exposição, componente crítico dos estudos de epidemiologia, é necessária para se examinar associações entre exposições ambientais e as conseqüências potenciais à saúde. Medições de dose interna são cruciais para se relacionar exposição com dose (farmacocinética - o que o corpo faz com o poluente) e dose com efeitos (farmacodinâmica - o que o poluente faz com o corpo).

\section{FIGURA 3 - Conceitos básicos para entendimento e avaliaçāo da saúde ambiental}

Objetivos da Avaliaçāo da Exposiçāo

Nivel

.Distribuiçăo

\# Pessoas

. Fontes de aprovisionamento

.Dose-alvo

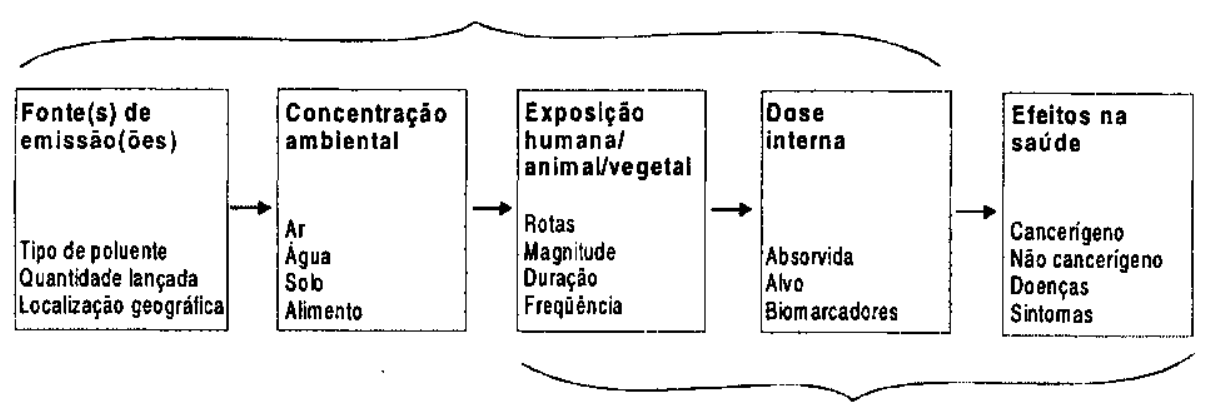

Objetivos da Avaliação de Efeltos na Saúde

. Riscos intrinsecos

Fonte: Sexton et al. (1992).

.Tipo de efeito

.Doseresposta 
As avaliações da exposição e dos efeitos à saúde humana são consideradas as duas fases mais importantes no estudo de risco à saúde causado por poluentes ambientais.

Na matriz da Figura 4, representa-se o paradigma conceitual que norteia a priorização dos problemas de saúde ambiental, no qual o mais alto nível deles inclui elevadas exposições (como os experimentados por um número significativo de pessoas) e poluentes muito tóxicos (como o perigo existente à baixa exposição/dose). O nível mais baixo de prioridade é dado à situação que combina baixo nível de exposição e pequeno número de pessoas com uma baixa toxicidade.

FIGURA 4 - Estrutura conceitual para se determinar prioridades na saúde ambiental

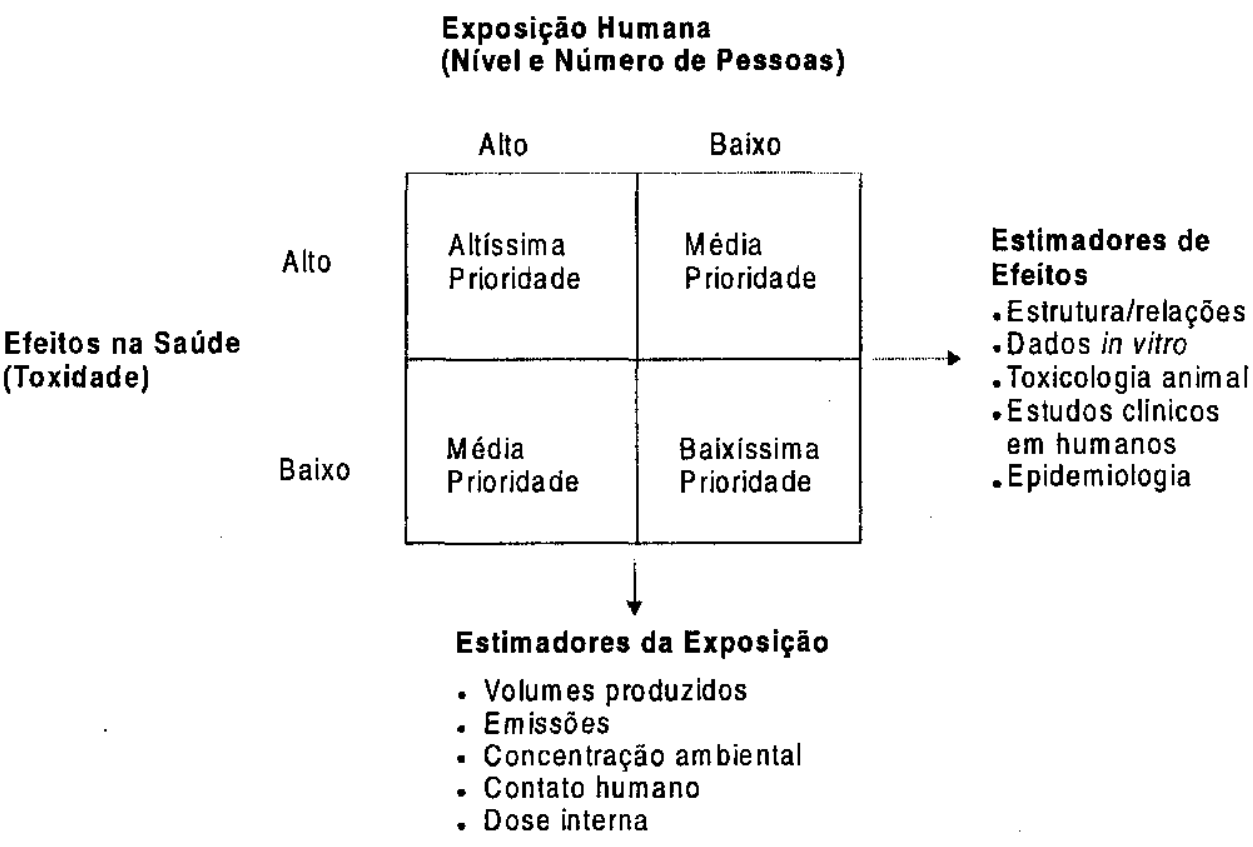

Fonte: Sexton et al. (1992). 


\section{Avaliação de Risco versus Avaliação de Saúde}

Existem diferenças intencionais entre Avaliação de Risco e Avaliação de Saúde. A seguir, apresentamos um resumo dos propósitos distintos formulados para a Avaliação de Risco adotada pela Agência de Proteção Ambiental Americana (Environmental Protection Agency - EPA) e pela Agência Americana para Substâncias Tóxicas e Registros de Enfermidades (Agency for Toxic Substances and Diseases Registry), no que se refere a substâncias perigosas (ATSDR, 1992).

\section{AVALIAÇÃO DE RISCO, SEGUNDO O EPA}

Uma Avaliação de Risco se define como um processo quantitativo e qualitativo conduzido para caracterizar a natureza e a magnitude dos riscos à saúde pública pela exposição a substâncias perigosas ou a contaminantes emitidos em sítios específicos. As Avaliações de Risco incluem os seguintes componentes: identificação do perigo, avaliação da dose-respostá, avaliação da exposição e caracterização do risco. Modelos biológicos e estatísticos são usados nas Avaliações de Risco químico e são quantitativamente orientados para o cálculo das estimativas numéricas do risco para a saúde, utilizando dados de investigações epidemiológicas em humanos (quando disponíveis) e estudos toxicológicos em animais.

O produto da Avaliação de Risco quantitativa é uma estimativa numérica das conseqüências, para a saúde pública, da exposição a um agente. Ao elaborar uma Avaliação de Risco para um sítio, o avaliador deve também incluir todos os efeitos na saúde, caracterizando o risco para as populações sensíveis quando se disponha de informação. As avaliações de risco do EPA săo usadas nas decisões de manejo do risco para estabelecer níveis de descontaminação (limpeza); para regulamentar os níveis autorizados para descarga; para manuseio e transporte de rejeitos perigosos; para determinar os níveis permissíveis de contaminação.

\section{AVALIAÇÃo de SAÚde, SEgundo a ATSDR}

As Avaliações de Saúde da ATSDR estão baseadas na informação da caracterização ambiental, nas preocupações da comunidade com a saúde e nos resultados dos efeitos nesta. Devido à natureza desses bancos de dados, as Avaliaçōes de Saúde usam informações tanto qualitativas quanto quantitativas, enfocando-se as perspectivas toxicológicas e de saúde pública associadas com a exposição no sítio.

A Avaliação de Saúde assinala especiticamente as preocupações de saúde da comunidade (como as populações sensíveis, os possíveis efeitos patológicos) e avalia os dados de efeitos pertinentes na saúde e específicos para a comunidade. A informação obtida dessas fontes, combinada com dados ambientais, é usada para determinar as implicações na saúde pública no sítio, aconselhando o início de atividades de acompanhamento de saúde, quando indicado. 
Em resumo, enquanto uma Avaliação de Risco do EPA é um processo utilizado para apoiar a seleção de uma medida de remediação em um sítio, a Avaliação de Saúde da ATSDR é um mecanismo que alimenta a comunidade com informações sobre as implicações de saúde pública em um sítio específico, identificando aquelas populações para as quais se requer estudos ou ações de saúde mais amplas. A Avaliação de Saúde também faz recomendações sobre as ações que sejam necessárias para proteger a saúde pública, o que pode incluir também a emissão de advertências em saúde.

\section{Avaliação de Impacto versus Avaliação de Risco Ambiental}

Um grande universo de pessoas discute se o Estudo de Impacto Ambiental (EIA) é parte de uma Avaliação de Risco Ambiental (ARA) ou se esta deveria ser um componente de um EIA. Para Andrew (1986), tanto um como o outro estão, em princípio, intimamente conectados. Embora não sejam processos idênticos, se utilizam dos mesmos conceitos e tradições e deveriam ser aplicados para mais ou menos os mesmos modelos de decisões. Isto requer a integração destes dois tipos de estudo.

As diferenças e similaridades entre EIA e ARA são observadas no Quadro 3. Nele, pode-se constatar que existem mais diferenças que similaridades entre os dois processos.

\section{QUADRO 3 - Comparações entre EIA e ARA}

\section{EIA}

Principais objetivos

Envolvimento do

público

- Envolve atividades: auto-estradas,

uso de solo, produção de energia, recursos hídricos, vazamento de óleo, indústrias contaminates etc.

- Năo envolve regulamentação sobre

Extensivo

ARA

Limitado

Envolve

Valor regulamentar

Influência nas decisōes $\quad$ - Importante

- Propor medidas mitigadoras

Propósito do estudo

- Considerações sobre impactos;

Legitimar decisōes de governo;

Subsílios para tomada de decisão

Decisão/processo administrativo

Importante

lgual

Riscos

Igual

Abrangência legal

FONTE: ANDREWS (1986). 
Do ponto de vista intelectual, o Estudo de lmpacto Ambiental e a Avaliação de Risco deveriam ser melhorados por meio da uniño de ambos, em um processo analítico unificado. O EIA podcria se beneficiar da maior sofisticução existente nos estudos de Avaliação de Risco, no tocante ao tratamento das análises de prediç̧es e de probabilidades e deveria, em qualquer caso, incorporar mais considerações explícitis dos efeitos na saúde. A ARA, por sua vez, deverial alargar seu campo de aplicação, incluindo mais riscos do que apenas mortalidade proveniente de câncer e de acidentes catastróliceos.

Em projetos como a delinição de sílios para localização de processos de produçāo de energia ou indústrias químicas, de aterros industriais para resíduos perigosos, aplicações de biotecnologias ou aplicaçōes de pesticidas para agricultura ou manejo florestal e outros afins, a integração EIA/ARA pode oferecer resultados muito mais completos que a execução de estudos separados. 


\section{REFERÊNCIAS BIBLIOGRÁFICAS}

Astan Development Bank (ADB) Guidelines: the health impact assessment of evelopment projects. Environmental Paper, 11, 1992.

Apes.. Manual de Alerta e Preparação de Comunidades para Emergências Locais. São Paulo: Programa Ambiental das Nações Unidas (United Nation Environmental Proteceion - Unep) / Associaçĩo Brasileira da Indústria Química e de Produtos Derivados (Abiquim), 1990.

ANDREws, R. N. Envirommental Impact and Risk Assessment: learning from Each Other. Draft copy of paper presented at International Institute for Applied System Analysis. Vienna, 1986.

ATSDR - Agency for Toxic Substanclis anis Deseases Registry. Evaluacion de Riesgos en Salud por la Exposición a Residuos peligrosos. Departamento de Salud Humana y Servicios de los E.E.U.U. Agencia para las Substancias Tóxicas y el Registro de Enfermidades, Atlanta, 30333, 1992.

Awazu, L. A. M. A Gestão dos Riscos de Acidentes Ambientais. Engenharia Ambiental. Ano 3, 9, jann. 1990.

Bergi:ir, I. S. Determination of Risk for Uncontrolled Hazardous Waste Sites. In: ProceEdings of the National Conferencl on Management or Uncontrolled Hazardous Waste Sites, Hazardous Matcrials Control Research Institute. Silver Spring, 1982. p.23-36.

Biвo, B. H. \& LemkowtTz, S. M. Chenical Risk Management: general risk anabsis model. Curso Risicobeheesing, Chemistry Faculty, TU Delli. Holland, 1994. p.23-36.

Bon.lA, M. \& Estevan, T. Evaluación del Impacto Ambicntal. Madrid: Fundación Maptre, 1984.

Branco, S. M. \& Rocha, A. A. Poluição-A morte de nossos rios. 2.ed. São Paulo, Convênio Cetesh/Ascetesb, 1987.

Brnl.hANTE, O. M. \& REZENDE, Deleccão da poluição por metais em poeiras, sedimentos, solos, águas pluviais c sistemas de sancamento através do magnetismo. Revista Brasileira de Ciência do Solo, 19(3). Campinas, 1995.

Brilhante, O . M. \& Oliveira, M. R. Environmental contamination by HCH in the Cidade dos Meninos', State ol Rio de Janciro. International Joumal of Environmental Health Research, 6:17-25, 1996.

CAJ.Kins, D. R. et al. Identificalion, characterization and control of potential human carcinogens: a lramework for federal decision-making. Journal of the National Cancer Institute, 61:169-175, 1980. 
CANTER, W. L. Environmental Risk Assessment and Management. A literature review. Pan American Center for Human and Health Ecology, Environmental Health Program. PAH, World Health Organization, Mexico, 1989.

Comission on Risk Assessment and Risk Management. Risk assessment and risk management in regulatory decision-making. Draft Report for Public Review and Comment, June 13, 1996.

Conselho Nacional do Meio Ambiente (Conama). Resolução no 001, de 23/01/86, que estabelece as definições, responsabilidades, critérios e diretrizes gerais para o uso e implementação da avaliação de impacto ambiental como instrumento de política nacional de meio ambiente. Secretaria Nacional do Meio Ambiente (Sema). Brasília, 1986.

ConwaY, R. A. Introduction to environmental risk analysis. In: Environmental Risk Analysis for Chemicals. New York: van Nostand Reinhold Company, 1982. chapter 1. p.1-30.

GLAD, P. H. A. Design and implementation of comprehensive environmental pollution control projects. In: Health and the Environment. Copenhagen, WHO, Regional Office for Europe, 1979.

Graedel, E. T. \& Crutzen, P. J. The changing atmosphere. Scientific American, 26I:3, Sept. 1989.

HANCOCK, T. Health, human development and the community ecossystem: three ecological models. Health Prmotion International, 8(1)41-47, 1993.

Hallenbeck, W. H. 'Introduction'. In: Hallienbeck, W. H. \& Cunningham, K. N. (Ed.) Quantitative Risk Assessment for Environmental and Occupational Health.

Chelsea, Michigan: Lewis Publishers, Inc., 1986. chapter 1. InHaber, H. Energy Risk Assessment. New York: Gordon and Breach Science Publishers, Inc., 1982. p. 1-54.

JEDRYCHOWSKI, W. Case control study of lung cancer with special reference to the effect of air pollution in Poland. Journal of Epidemiology and Community Health, 44:1 14-120, 1990.

KaZAKov, V. S. Thyroid cancer after Chernobyl. Nature, 365:702, 1992.

Lambert, G. Le Gaz à Effet de Serre. La Recherche, 23:243, 1992.

Margulis, S. Meio Ambiente. Aspectos Técnicos e Econômicos. Brasilia, Ipea/PNUD, 1990.

MinISTERIE VAN VolkshuISVESTING. Nederlands Milieubeleid. VROM 91559/:1/. 4881/101, The Hague, 1992. 
National. Research Council. Risk Assessment in the Federal Govermment: managing the process. Washington, D.C.: National Academy Press, 1986.

Oliveira, R. M. \& BRILhaNTE, 0. M. HCH contamination in one urban area of the Southeast of Brazil. Journal of Public Health / Saúde Pública, 29(3), USP. São Paulo, 1995.

Pershagens, G. Residential Radon exposure and Lung Cancer in Sweden. A Nation wide case control study. IMM-Repport 2/93. Stokolms, Karolinska Institute, 1993.

SAdourny, R. L'Homme Modifie-t-il le Climat?. La Recherche, 23:243, 1992.

SCIENCE \& VIE. Dernières Nouvelles de la Planète. Paris: Excelsior Publications S. A., out. 1991. (Dossier Hors Serie, 6)

Sexton, K. et al. Estimating Human Exposure to Environmental Pollutants: availability and utility of existing databases. Archives of Environmental Health, 47(6):398-407, 1992.

SoRs, A. I. Risk assessment and its use in management: a state of the art review. In: Proceedings of a Seminar on Evaluation and Risk Assessment of Chemicals. WHo, Regional Office for Europe. Interim Document. Copenhagen, 1982. p.236-294.

StewarT, I. Risk business. New Scientist (UK), 33, May 1990.

The EConomist. For Kyoto, a modest proposal. Nov, 29 th, 1997.

World Health Organization (WHO). Health and the Environment. Regional Oftice for Europe. Copenhagen, 1979. (Public Health in Europe, 8)

World Health Organization (WHO). Environmental and Health, the Eumpean Charter and Commentary. In: First EUROPEAN CONFERENCE ON ENVIRONMENT AND HEALTH, Dec. 1989, Frankfurt. Regional Publication, 1990. (European Series, 35)

World Health Organization (WHO). Concern for Europe's tomorrow. Summary. World Health Organization. Regional Publications, 1994. (European Series, 53)

WORLD BANK. Technique for assessing industrial hazards: a manual. World Bank Technical Paper, 55, 1990.

World Development Report. Investing in Health. Oxford: Oxford University Press, 1993. 



\section{PROCEDIMENTOS \\ INTEGRADOS DE RISCO \\ E GERENCIAMENTO \\ AMBIENTAL: \\ PROCESSOS E MODELOS}

HORST MONKEN FERNANDES

LENE HOLANDA SADLER VEIGA

Ao longo dos últimos anos, tem crescido bastante o interesse pela qualidade do meio ambiente. Aneaças relacionadas a mudanças climáticas no planeta, e à redução do nível de ozônio na atmosfera ganharam grande espaço nos veículos de comunicaçāo. Dessa forma, torna-se clara a percepção de que o homem está relacionado ao meio de uma maneira bem mais complexa do que simplesmente pela exposição a produtos tóxicos.

Dois pontos de inferências (end-points) podem ser considerados como resultado das intervenções antropogênicas no mcio ambiente: um relacionado ao risco à saúde humana (ponto de inferência humano) e outro ao risco ecológico (ponto de inferência ecológico) (Hoffinan et al., 1991).

Com o objetivo de se abordar os impactos ambientais segundo os dois pontos anteriormente citados, têm sido muito utilizados os conceitos de Avaliação de Risco e de Gerenciamento de Risco. O estímulo para a adoção da Avaliação de Risco como componente fundamental na regulamentação ambiental reside no recontecimento de que:

- o custo de se eliminar todos os efcitos de uma intervenção no ambiente é proibitivamente alto;

- as tomadas de decisão são, de uma forma geral, feitas com base em informações cientílicas incompletas (Barnthouse ct al., 1986).

Neste contexto, o objetivo de regulamentação ambiental baseado na Avaliação de Risco é o de balancear o nível de risco aceitável em razão do custo na redução do risco, em contraposição a outros riscos ou contra-riscos geralmente aceitos pelo público. 
O sentido comum atribuído ao termo 'risco' está relacionado à ameaça de um evento indesejável que inclui tanto a probabilidade quanto o caráter do evento. Segundo as recomendações da International Commission for Radiological Protection (ICRP), inicialmente o risco era tido como quantidade caracterizada por uma magnitude expressa numa unidade adimensional, se tivesse o sentido de probabilidade, mas dimensional se tivesse o sentido da expectativa matemática de uma conseqüência. É claro que, no sentido amplo, a palavra 'risco' se torna muito mais um conceito do que uma quantidade, muito embora possa ser tida como uma quantidade de atributos múltiplos.

A Avaliação de Risco, no sentido de risco ambiental, deixa de configurar uma visão única de avaliação de probabilidade para incluir outros aspectos do risco, como a natureza e a severidade das conseqüências prejudiciais.

Um esquema operacional para ser utilizado na Avaliação de Risco é apresentado na Figura 1. Neste processo, os pontos terminais a serem avaliados são primeiramente selecionados. Em seguida, procede-se uma descrição técnica da instalação/empreendimento, vista aqui como fonte potencial dos impactos. Em terceiro lugar, descreve-se o ambiente no qual o impacto será desenvolvido (ambiente de referência). A cxposição aos contaminantes é, então, avaliada. Modelos ambientais de transferências podem, dessa forma, ser utilizados para se estimar a exposição.

No bloco relativo à avaliação dos efeitos, dados toxicológicos disponíveis são analisados com o objetivo de se determinar os efeitos dos contaminantes sobre os organismos expostos.

Finalmente, todas as etapas são combinadas para se produzir a Avaliação de Risco final, que expressa quantitativamente os efeitos dos contaminantes contidos no Termo Fonte paral os diferentes pontos de inferências.

Este fluxograma pode ser utilizado, com ligeiras adaptações, tanto para os pontos de inferências humanos como para os ecológicos.

Cardinal (1991) compara a percepção do público quanto à exposição ao asbesto $\mathrm{c}$ ao radônio. Enfatiza que, na medida em que os cientistas encaram a determinação do risco como um processo téenico, o público se posiciona de forma a tratar o problema como um processo de decisão pessoal. No referido texto demonstra-se o que a reação adversa do público ao asbesto foi muito mais intensa do que ao radônio. Contribuiu para essa postura o fato de que a exposição ao asbesto pode ser percebida, ao passo que ao radônio (um gás nobre), não; este último ocorre naturalimente, já o asbesto ć tido como uma substância nãonatural; trabalhadores que o manipulaun estão, comprovadamente, sujeitos a desenvolvimento de câncer, mas não se possui, segundo a autora, nenhum caso "documentado" de câncer contraído devido ao radônio.

Os aspectos até aqqui abordados apontam para uma relação risco versus benefício de tal forma que se alcance uma redução do primeiro e a otimização do segundo. O nível de redução do risco não é infinito. A partir de um certo ponto, essa redução torna inviável a execução de certas atividades, ou tornam-se desprovidas de sustentação racional. 


\section{FIGURA 1 - Fluxograma operacional para a avaliação do risco de substâncias tóxicas}

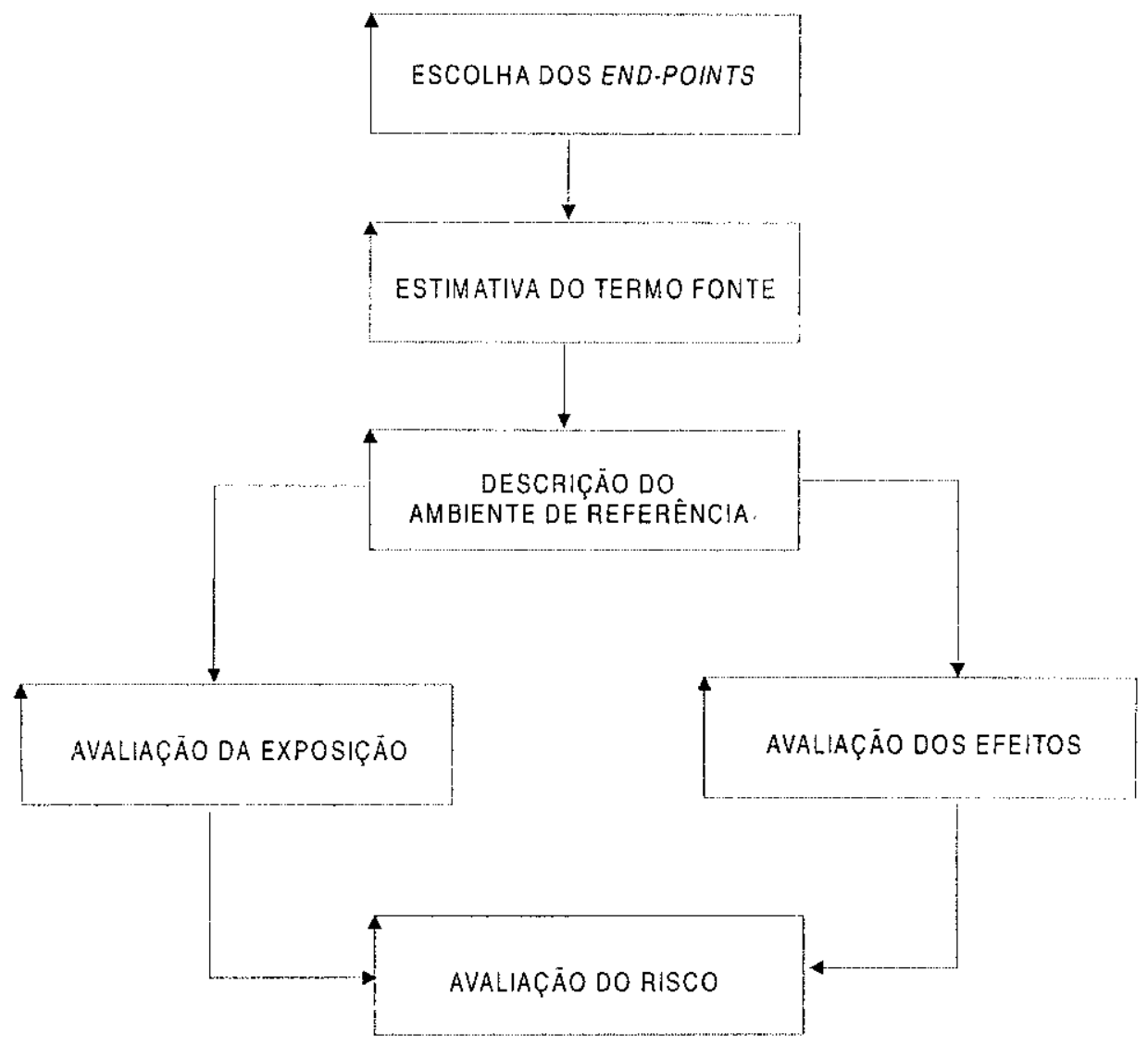

Fonte: Adaptado de Barnthouse et al. (1986).

Um exemplo disso pode ser visto no trabatho desenvolvido por Fernandes et al. (1993). Os autores questionam a necessidade de se aplicar U $\$ 200$ mil anuais (somente com calcério) no tratamento de efluentes de uma mineração de urânio para se reduzir a dose efetiva anual, comprometida devido à exposiç̧ão ao ${ }^{2.3 x} \mathrm{U}$ e ao ${ }^{22 n} \mathrm{Ra}$, de $0.50 \mathrm{mSv}$ para $0.05 \mathrm{mSv}$, quando o limite de dose recomendado para exposição pública é de $1 \mathrm{mSv} / a n o$ (International Commission on Radiological Protection, 1991).

Um polêmico tema se insere no fundo de todas essas decisões, referente ao valor da vida humana. Bellia (1991) ressalta que, ao se atribuir um valor incalculável à vida, qualquer empreendimento que pudesse causar a perda de uma única vida seria considerado 
inviável, do ponto de vista econômico. No entanto, várias são as práticas que agregam um agravamento de acidentes que acarretam morte. Apesar disso, são amplamente aceitas pela sociedade, que voluntariamente se beneficia de tais atividades. Nessas circunstâncias, cada indivíduo tende a subestimar a probabilidade de estar incluído no universo daqueles que estariam inseridos na estimativa do risco daquela atividade. Com essa postura, rompem-se as barreiras morais que inviabilizam o projeto. $O$ importante a se pensar, ainda segundo Bellia (1991), é que as quantias a serem abatidas dos benefícios não são as que compensam qualquer número específico de pessoas pela certeza de morte prematura ou pela saúde abalada, mas aquelas variações que compensem todos os membros da sociedade pelos riscos adicionais a que estarão expostos com a realização do projeto.

A conceituação da relação risco versus benefício torna-se ainda mais complexa quando se aborda o risco ecológico, já que este não se vincula de forma direta com a saúde humana, muito embora a relação entre esta e o meio ambiente equilibrado seja aparente (Bartell, 1992). Impactos desse tipo podem scr o declínio indesejável de uma comunidade de predadores por pesticidas, uma extinçāo local de espécies animais e/ou vegetais, substituição de peixes de alto valor comercial por populações menos valiosas, uma mudança na capacidade de um ecossistema depurar certo tipo de rejeito ou, ainda, uma mudança adversa nas composiçōes físico-químicas do ambiente (depleção de ozônio na atmosfera, deposição ácida, mudança do clima global etc.).

\section{Metodologia Integrada de Avaliação de Risco e Gestão}

\section{AMBIENTAL}

Do que foi discutido até o momento, fica nítido que a abordagem holística das conseqüências das intervenções antropogênicas no ambiente deve agregar diferentes aspectos do conhecimento. Isto significa a própria característica inter e multidisciplinar resultante dos estudos ambientais. Esta visão integrada será desenvolvida, daqui por diante, com a designação de Avaliação de Risco e Gestão em Poluição Ambiental, metodologia que inclui os seguintes aspectos:

- princípios de Gestão Ambiental;

- elaboração de cenários e modelos conceituais;

- Avaliação de Risco para a saúde humana;

- Avaliação de Risco Ecológico;

- instrumentos de gestão, alternativas/avaliação de custo.

Neste presente capítulo serão abordados os dois primeiros itens dessa metodologia. Os referentes à Avaliação de Risco para a saúde humana e à Avaliação de Risco Ecológico serão discutidos no capítulo 3 . O que se refere aos instrumentos de gestão é apresentado no capítulo 1. 


\section{Gestāo Ambiental (Princíplos e Aplicaçōes)}

O ponto de partida para a compreensão de Gestão Ambiental se articula com a idéia de que, no presente, a avaliação dos impactos resultantes do desenvolvimento sobre os recursos naturais não é uma prálica lactível. É neccssário, no entanto, avaliar as consecuüências que os impactos sobre os recursos naturais trarão ao objetivo do crescimento a longo prazo (Bellia, 1991). De forma resumida, pode-se dizcr que o objetivo básico da Gestão é a busca da otimização do uso dos recursos que o homem tem a sua disposição, sejam de ordem financeira, material ou humana.

Verifica-se, a seguir, um esquema de filosofia de Gestão Ambiental, tal como proposto por Bellia (1991):

- Objetivo: manter saudável o meio ambiente, 'na medida do possível', para atender às necessidades humanas atuais, sem comprometer o atendimento das necessidades das gerações futuras.

- Meios: atuar sobre as modificições causadas no meio ambiente, pelo uso e/ou descarte dos bens e detritos gerados pelas atividades humanas, a partir de um plano de ação viável téenica e economicamente, com prioridades perfeitamente delinidas.

- Instrumentos: monitoramentos, controles, taxaçōes, imposições, subsídios, divulgações, obras e ações mitigadoras etc.

- Base de Aluação: diagnóstico ambiental da área de atuaçãa, a partir de estudos e pesçuisas dirigidos à busca de soluções para os problemas que forem detectados.

Embutidos nestes dois primeiros itens cncontram-se termos que vão nortear ats avalliações técnico/científicas a serem descritas adiante. Primeiramente, a definição da extensão da expressĩo 'na medida do possível' - e seria importante acrescentar, 'necessário' -, no que tange à manutenção do meio ambiente saudável. Em seguida, a deliniç̧ão das "modilicações impostas ao mcio pelo seu uso ou descarte de matcriais gerados pelas ações antropogênicas' para se atingir esses objetivos e possibilitar a áplicação de técnicas e soluçôes que do ponto de vista econômico viabilizem o projeto $\mathrm{c}$ assegurem o bem-estar da população e a integridade relativa do meio. Tais medidas se inserem nos próximos temas.

\section{Elaboraçāo de Cenários e Modelos Conceituais}

Na elaboração de cenários, um primciro procedimento se articula com a definiçāo do Termo Fontc. A expressão tem sentido idêntico ao que the é atribuída no campo da Avaliatção de Impacto Radiológico. Tal definição é entendida como um processo linear no qual os efeitos à saúde, devido ao lançamento de materiais radioativos no meio, dependerão diretamente da quantidade e da forma de cada radionuclídeo lançado. Esse inventário, que compreende todos os radionuclídeos de interesse, é o que se denomina de Termo Fonte (Eicholr, 
1983). Analogamente às atividades poluidoras não-radioativas, vulgarmente conhecidas como convencionais, a natureza do Termo Fonte irá variar de acordo com o processo e da instalação que está sendo considerada. Importante ressaltar que qualquer espécie contida no Termo Fonte será de interesse somente se for móvel no meio ambiente, ou seja, se for capaz de escapar qualquer contenção numa forma físico-química que possibilite seu trânsito ao longo dos caminhos ambientais. Tal conceito implica consideração da possibilidade de escape das espécies em virtude das contenções nos procedimentos de rotina ou em situações de emergência.

Do ponto de vista do lançamento e da mobilidade, os parâmetros importantes a serem levados em conta na caracterização do Termo Fonte são: o estado físico das espécies (líquido, sólido ou gasoso); o tipo de agregação (microparticulado, coloidal); a forma química (solubilidade no ar e água, estado de oxidação, propriedades de sorção e volatilidade) e a quantidade liberada.

Uma vez conhecidos e quantificados os agentes poluidores, será necessário a definição do cenário onde esses materiais irão atuar. A descrição do cenário, aqui significa o compreendimento das interações dos diferentes compartimentos ambientais entre si, a extensão das suas comunicabilidades, no que diz respeito aos processos de transferência dos agentes poluidores lançados etc.

Se é estabelecido o homem como ponto terminal nesta avaliação, a sua forma de comunicação com o meio, tida aqui como exposiçāo, deve ser também levada em conta. Nas Figuras $2 \mathrm{e} 3$, apresentam-se formatações esquemáticas genéricas dos possíveis processos de transporte de poluentes, a partir de emissões gasosas e líquidas, até atingir o ser humano.

Os mecanismos ambientais envolvidos na dispersão dos poluentes além de envolverem as particularidades dos agentes poluidores, como já citado anteriormente, deverão englobar as especificidades dos meios. O grau de complexidade com que se irá abordar (descrever) o cenário, bem como os processos de transferência intra e intercompartimentos, implicará maior esforç̧o de aquisição de informações, o que nem sempre resultará em uma melhor resoluçãao ou exatidão da resposta à questão formulada.

As transformações de um poluente, num sistema aquático natural, podem ser tratadas em diferentes níveis de complexidade. Em alguns casos, para simplicidade de cálculos, assume-se que a espécie em questão permanecerá em solução e sua concentração na coluna d'água irá diminuir por diluição, como resultado de processos de difusão, advecção ou mesmo decaimento. Nesses casos, a tendência é de se observar uma superestimativa no resultado final, especialmente se processos de adsorçâao a partículas e, por conseguinte, perdas do sistema por sedimentação forem verificadas. A adsorção a sedimentos terá o efeito imediato de reduzir a concentração do poluente na água e conseqüentemente o impacto inicial, mas o sedimento contaminado poderá vir a ser uma fonte residual de poluição via processos de ressuspensão, dessorção e turvaçăo.

A definição e descrição dos processos potencialmente relevantes na dinâmica e trans. porte de poluentes, em um dado meio, nāo devem ficar restritas a aproximações qualitativas. Juntamente com os balanços hídricos, cálculos de capacidade de suporte e balanços de massa, os processos biogeoquímicos devem ser quantificados ou estimados. 
FIGURA 2 - Emissão gasosa

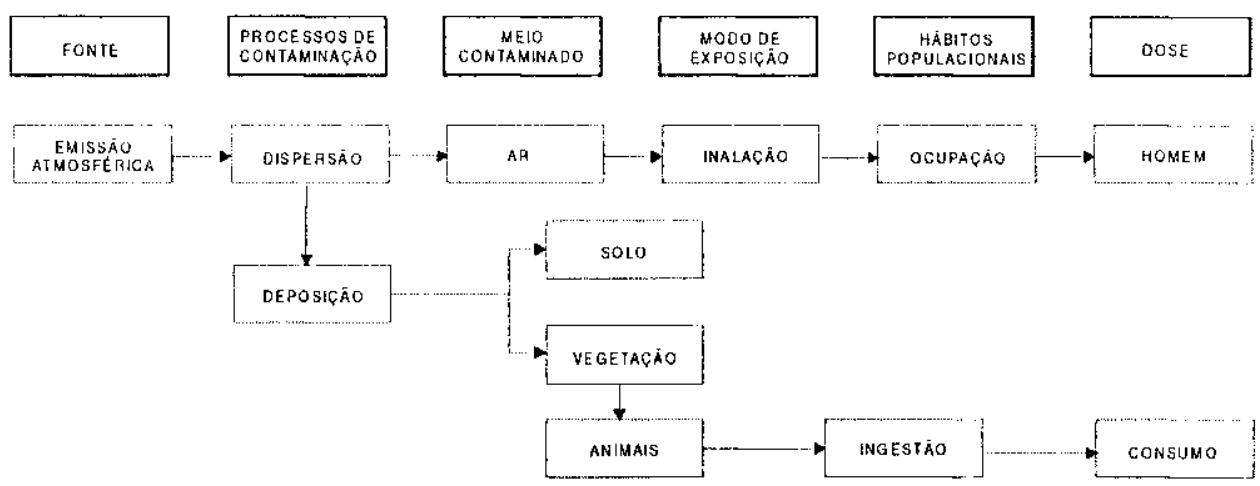

FIGURA 3 - Emissão líquida

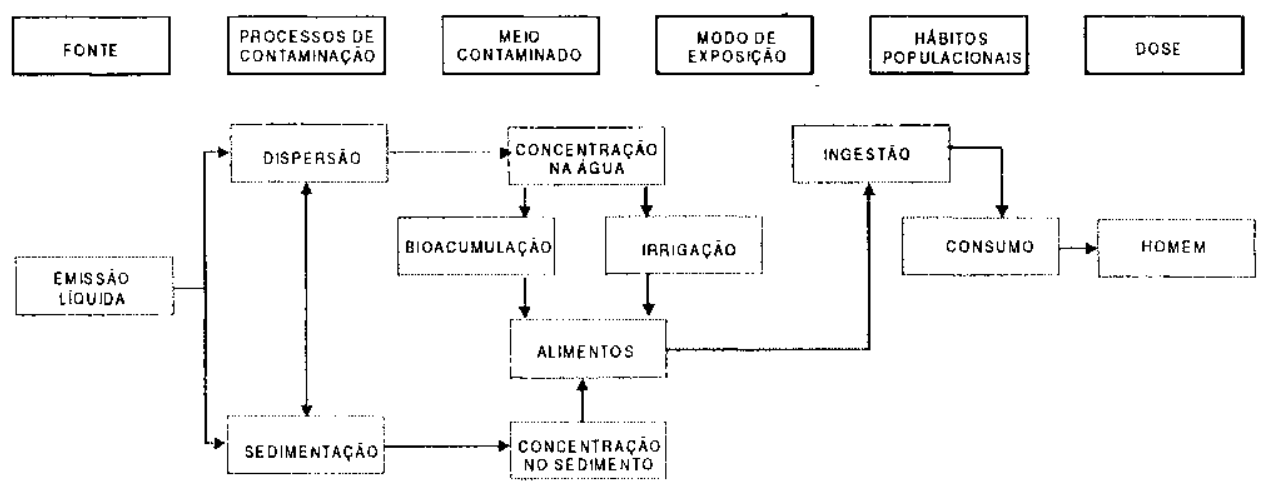


Uma representação esquemática genérica pode ser proposta para a realização de balanços de massa nos quais os processos são considerados:

\begin{tabular}{|c|c|c|c|c|c|c|c|c|}
\hline $\begin{array}{l}\text { Transferência } \\
\text { de massa }\end{array}$ & ou & $\begin{array}{c}\text { Acumulação } \\
\text { ou } \\
\text { Exportação } \\
\text { ou } \\
\text { Equilíbrio }\end{array}$ & $=$ & $\begin{array}{l}\text { Afluência } \\
\text { (input) }\end{array}$ & - & $\begin{array}{l}\text { Influência } \\
\text { (output) }\end{array}$ & $+1-$ & $\begin{array}{r}\text { Massa interna } \\
\text { (Adicionada/ } \\
\text { Transformada/ } \\
\text { Suprimida) }\end{array}$ \\
\hline
\end{tabular}

Os processos biogeoquímicos correspondem a eventos internos a um determinado meio ou segmento de meio; estão relacionados ao termo ( $+/$ - massa interna) na equação, sendo expressos na forma de velocidade ou taxas de processo (liberação/transforma(̧ão/supressão).

A integração dos vários processos, representados nos modelos por meio de equações matemáticas, vão possibilitar a simulação do comportamento do cenário ante a cmissão dos poluentes a partir do Termo Fonte. Tais simulaçōes, vistas aqui como uma mímica do meio, são úteis numa fase pré-operacional da instalação do projeto, de forma a possibilitar a otimização do lançamento dos efluentes, bem como são instrumentos fundamentais em tomadas de decisão nos eventos de acidentes.

\section{Modelagem Ambiental}

O processo de modelagem ambiental é aquele no qual as relações entre os compartimentos de um ecossistema são identificadas e descritas. Como visto anteriormente, pode ser empregado na simulação das condições ambientais, avaliação dos efeitos de um projeto/ instalação, assim como na projeção de alternativas mitigadoras (York \& Speakman, 1980).

Todos os modelos de avaliação ambiental são inerentemente incertos. É preciso ter em mente, e aqui não cabem preciosismos, que no fundo os dados de saída se constituem em aproximaçōes dos processos que se desenrolam no meio. A substituição de hipóteses conservativas por outras de caráter mais realista, sem a devida avaliação das incertezas inerentes aos parâmetros, poderá acarretar aumento da probabilidade de subestimação. Devemos lembrar, no entanto, que a especificação do problema (constituição do cenário) é $o$ aspecto mais relevante. Além dessa etapa, outros grupos de eventos, tal qual apresentado na Figura 4, podem afetar a confiabilidade das previsões de um modelo matemático. 


\section{FIGURA 4 - Cinco classes de fatores que afetam a confiabilidade das previsões de modelos matemáticos}

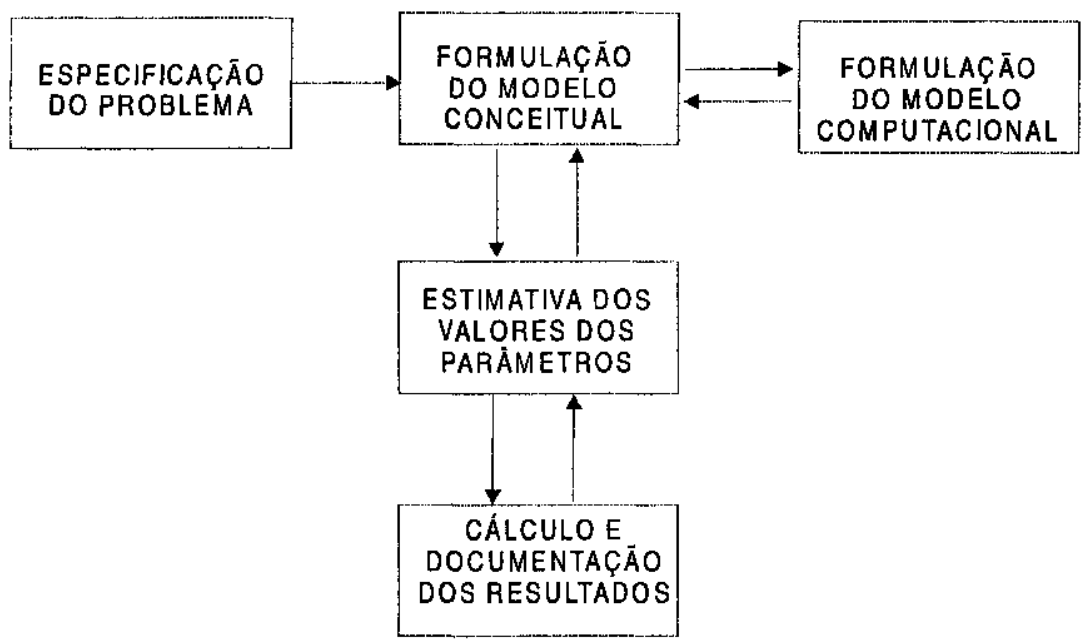

Fonte: Adaptado de Hoffman \& Hofer (1988).

Os erros concernentes a uma estimativa imprópria de parâmetros e formulação imprópria do modelo são muito sensíveis quando as previsões são feitas para condições distintas daquelas para as quais o modelo e sua base de dados foram inicialmente concebidos.

A variabilidade dos parâmetros, como fonte de incerteza, está relacionada ao uso de modelos determinísticos. Neste tipo de modelo é utilizado um único valor para cada parâmetro, de modo a produzir uma única previsão. Tais modelos ignoram o efeito de estimativas imprecisas para cada parâmetro e a variabilidade do sistema. Para qualquer situação em que for necessário o emprego de modelos matemáticos, os parâmetros são melhor representados por uma faixa (distribuição) de valores. Esta faixa se traduz em outra, relativa a previsões do modelo. Pode-se postular, dessa forma, que o contorno ao problema da imprecisão dos parâmetros poderá ser conseguido por intermédio de abordagens probabilísticas, ao invés de determinísticass.

O primeiro passo na análise da incerteza de um modelo é o de se limitar o seu escopo. Isto requer uma explícita definição dos objetivos da avaliação cm questāo e a detcrminação dos agentes poluidores, vias de exposição e parâmetros do modelo mais relevantes. Este processo implica economia de recursos financeiros, esforços de avaliação de processos não-relevantes e hora/homem de trabalho. A relevância dos poluentes específicos, vias de 
exposição e parâmetros pode ser determinada por simples processos de triagem (screening) ou por meio de métodos matemáticos de análise de sensibilidade mais rigorosos.

A maneira mais simples de se desenvolver um processo de triagem para poluentes $\mathrm{e}$ vias de exposição menos significativas, no resultado final do modelo, é o de se compararem as previsões do modelo contra limites arbitrários ou padrões reguladores. Neste processo, todos os poluentes e vias de exposição que contribuem, numa quantidade menor que uma fração especificada do valor final, são omitidos de análises posteriores.

\section{EXEMPLO 1:}

Vamos admitir que a legislação vigente estabeleça um limite de ingestão para uma dada substância tóxica na ordem de $10 \mathrm{mg} / \mathrm{dia}$. Uma avaliação conduzida numa população potencialmente exposta a esta substância, lançada no meio ambiente (atmosfera e meio aquático) por uma dada indústria forneceu os seguintes valores:

\begin{tabular}{ll}
\hline Vias de exposição & $\begin{array}{l}\text { Dose prevista } \\
\text { (mg/dia) }\end{array}$ \\
\hline Meio aquático & 0,03 \\
Peixe & \\
\hline Meio terrestre & 0,05 \\
Inalação & 0,10 \\
Ingestão de vegetais & 0,80 \\
Ingestão de leite & 0,20 \\
Ingestão de carne & 11,18 \\
\hline Total & \\
\hline
\end{tabular}

Se utilizarmos um critério de triagem, da ordem de $5 \%$ do valor limite de $10 \mathrm{mg} / \mathrm{dia}$, chegaremos a conclusão de que apenas a via de ingestão por leite excederia o critério adotado (isto é, $5 \%$ do valor- limite), e o escopo do problema seria reduzido a um maior esforço de controle desta via em detrimento das demais.

Poderíamos propor ainda um outro critério de triagem, por exemplo a adoção de um valor da ordem de $10 \%$ do valor total da nossa avaliação, ou seja, $0,12 \mathrm{mg} / \mathrm{dia}$. Neste caso, incluiríamos aí, além da ingestão de leite, aquela relativa à carne. Os critérios de screening assumidos num processo desse tipo devem ser adotados de tal maneira que sejam suficientemente pequenos para não rejeitarem nenhuma via de exposição relevante. 
Um outro procedimento utilizado é o da análise de sensibilidade, que consiste na perturbação de cada parâmetro do modelo por uma pequena quantidade -, deixando-se que os demais permaneçam nos valores nominais pré-selecionados -, e quantificando-se o eleito relativo daquele parâmetro na previsão do modelo. Os parâmetros que tiverem maior influência nas previsões do modelo são designados como sendo os mais sensíveis. Todavia, em inodelos ambientais, grandes incertezas ou variabilidades paramétricas podem produzir resultados muito diferentes daqueles obtidos por pequenas perturbações. Por essa razão, recomenda-se que as análises de sensibilidade sejam feitas por meio da variaçăo de cada parâmetro ao longo de sua faixa de variação esperada (Hoffinan \& Gardner, 1983).

\section{EXEMPLO 2:}

Uma das estruturas mais simples, utilizada em modelos de transferência com propósitos de Aval jaç̧ão de Impacto Ambiental, se relaciona com cadeias multiplicativas, conforme exposto a seguir:

Dose $=\mathrm{Q} * \mathrm{~A} * \mathrm{~B} * \mathrm{C}$

Onde:

$\mathrm{Q}=$ Taxa de liberação

$\mathrm{A}=$ Dispersão na atmostera ou meio aquático

$B=$ Transferência através de cadeia alimentar

$\mathrm{C}=$ Taxa de consumo de alimento

Vamos considerar, agora, a seguinte equação:

$$
C=\frac{d \cdot R\left[I-\exp \left(-L w \cdot t_{c}\right)\right]}{Y_{v} \cdot L_{w}}+\frac{B_{i v}\left[I-\exp \left(-L_{s} \cdot t_{b}\right)\right]}{P \cdot L_{s}}
$$

Onde:

$\mathrm{C}=$ Concentração na vegetação $(\mathrm{mg} / \mathrm{kg})$.

$\mathrm{d}=$ Taxa de Deposição média $\left(\mathrm{mg} /\left(\mathrm{m}^{2} \cdot \mathrm{d}\right)\right.$.

$\mathrm{R}=$ Fração da Deposição inicial interecptada pela porção comestível da vegetação adimensional).

$\mathrm{Y}_{v}=$ Biomassa comestível da vegetiçāono $\left(\mathrm{kg} / \mathrm{m}^{2}\right)$.

$L_{w}=$ Constante de remoção da substância da superfície da vegetação (L/d). 
$\mathrm{T}_{\mathrm{c}}=$ Período de Tempo que a vegetação está exposta ao ar contaminado (d).

$\mathrm{B}_{\mathrm{is}}=$ Razão entre a concentração no solo e a concentração na planta (adimensional).

$\mathrm{P}=$ Densidade superficial efetiva do solo numa profundidade de raiz especítica $\left(\mathrm{kg} / \mathrm{m}^{2}\right)$.

$\mathrm{L}_{\mathrm{s}}=$ Constante de perda para a substância no solo - lixiviaçăo (d-L).

$\mathrm{T}_{\mathrm{h}}=$ Tempo em que o solo está exposto ao ar contaminado (d).

Para este exemplo, observe a seguir:

\section{Tabela 1 - Valores nominais pré-selecionados e faixas de variação para os} parâmetros do modelo

\begin{tabular}{cccc}
\hline Parâmetro & Valor Mínimo & Valor Nominal & Valor Máximo \\
\hline$r$ & 0,05 & 0,2 & 0,5 \\
$\mathrm{Y}_{\mathrm{v}}$ & 0,5 & 1,0 & 2,0 \\
$\mathrm{~L}_{\mathrm{w}}$ & 0,035 & 0,05 & 0,07 \\
$\mathrm{~T}_{\mathrm{c}}$ & 30 & 45 & 60 \\
$\mathrm{~B}_{\mathrm{iv}}$ & 0,01 & 0,06 & 0,5 \\
$\mathrm{P}$ & 200 & 220 & 250 \\
$\mathrm{~T}_{\mathrm{b}}$ & 5500 & 11000 & 18000 \\
$\mathrm{~L}_{\mathrm{s}}$ & $1 \mathrm{E}-05$ & $1 \mathrm{E}-03$ & $8 \mathrm{E}-03$ \\
\hline
\end{tabular}

Obs: $\mathrm{O}$ valor de $\mathrm{d}$ foi assumido como constante.

Tomemos agora o termo IS (Índice de Sensibilidade) como sendo:

$$
I S=I-\frac{C_{\mathrm{MAX}}}{C_{\mathrm{MIN}}}
$$

Onde $\mathrm{C}_{\mathrm{MAX}}$ é obtido pelo cálculo de $\mathrm{C}$ com o valor máximo de um determinado parâmetro, os outros sendo mantidos nos seus valores nominais. Analogamente, $\mathrm{C}_{\mathrm{MIN}}$ ć o valor de C obtido com o valor mínimo deste mesmo parâmetro. Se fizermos isto com todos os parâmetros do modelo, poderemos ter uma idéia geral do Índice de Sensibilidade de cada un deles e hierarquizá-los conforme exposto na tabela seguinte: 


\section{Tabela 2 - Índice de Sensibilidade de cada parâmetro no modelo}

\begin{tabular}{ll}
\hline Parâmetro & $\begin{array}{l}\text { Índice de } \\
\text { Sensibilidade }\end{array}$ \\
\hline $\mathrm{r}$ & 0,90 \\
$\mathrm{Yv}$ & 0,75 \\
$\mathrm{Lw}$ & 0,22 \\
$\mathrm{Te}$ & 0,02 \\
$\mathrm{Biv}$ & 0,02 \\
$\mathrm{P}$ & $<0,01$ \\
$\mathrm{~Tb}$ & $<0,01$ \\
$\mathrm{Ls}$ & $<0,01$ \\
\hline
\end{tabular}

Um Índice de Sensibilidade da ordem de 1.0 indica completa sensibilidade do parâmetro no resultado final do modelo. Já um índice $<0.01$ indica que o modelo é insensível a mudanças no valor do parâmetro. Desse modo, a equação do modelo pode ser reescrita da seguinte forma:

$$
C=\operatorname{d} r\left[Y_{v} \cdot L_{w} I^{\prime}\right.
$$

Neste contexto, a análise de sensibilidade se torna uma útil ferramenta na redução do número de parâmetros e vias de exposição que devem ser consideradas prioritárias na análise das incertezas do modelo.

\section{VALIDAÇÃo de Modelos}

Segundo Hoffman \& Gardner (1983), a validação de um modelo é o melhor meio de se analisarem as incertezas associadas com suas previsões. Os autores reconhecem a existência de várias interpretações do que seja um modelo validado. A aceitação da acuracidade de um modelo é uma determinação subjetiva e irá variar de caso a caso.

A validação de modelos de avaliação de poluição começa com a comparação de uma quantidade singular prevista contra uma distribuição de medidas observadas. Para cada conjunto de condições selecionadas para fins de teste do modelo são produzidas quantidades previstas e medidas diferentes. Esses resultados podem ser comparados dividindo-se cada previsão pela distribuição correspondente de valores medidos, para produzir-se uma 
Irequiência de distribuição de razões Previstas/Observadas $(\mathrm{P} / \mathrm{O})$ para cada conjunto de condições. As razões $\mathrm{P} / \mathrm{O}$ podem ser conjugadas numa distribuição geral, representando a incerteza geral associada com as aplicações genćricas do modelo.

Uma outra mancira de se avaliar o desempenho de um modelo é obtida através da comparação das previsões do modelo com as observações ao longo de uma faixa de condições ambientais, testando-se as correlaçôes entre os resultados previstos e observatdos.

Fortes correlaçōes indicam que as diferenças entre as cbservaçōes podem ser expliciddas pelo modelo. Fracas correlações indicam que diferenças entre as observações são controladas por latores não solucionados no modelo.

A questão que se coloca agora é: o que se deve fazer quando informações para validação não são disponíveis ou suficientemente completas para se quantificarem as incertezas do modelo?

Nesses casos, recomenda-se o uso do processo de análise de incertezas paramétricas (Hoffman \& Gardner, 1983). O método consiste no uso de distribuiçãa de freqüências estimadas de valores para cada parâmetro do modelo, a tim de se produzir uma distribuição de freqüências para as previsōes do modelo.

As distribuições dos resultados do modelo podem ser comparadas com as previsões determinísticas ou com limites preestabelecidos para se estimarem as distorções potenciais e a possibilidade de os limites estabelecidos serem excedidos.

O primeiro passo na análise de incertezas paramétricas é o de se determinar as variaçöes potenciais dos valores associados a cada dado de entrada do modelo. Numa concepção ideal, os valores dos parâmetros devem ser derivados de levantamentos especílicos do sítio em questão. Quando existir um conjunto de dados adequado - tanto a distribuição estatística como seus momentos -, média e variância podem ser determinadas para cada parâmetro.

Na prática, é raro verificar-se a existência de dados específicos do sítio. Muitos parâmetros podem ser estimados somente de forma indireta a partir de valores similares reportados na literatura. Dessa forma, um esforço considerável deve ser investido na busca de dados relevantes.

O desenvolvimento de métodos computacionais para resolver numericamente os efeitos combinados da incerteza paramétrica, nas previsões do modelo, tem sido uma área de rápjido crescimento. Os métodos más utilizados são relacionados ao Cálculo de Monte Carlo, gue seleciona randomicamente os valores para os parâmetros do modelo a partir de uma distribuição pré-selecionada. Este método produz um único valor previsto, ou soluçāo do modelo, a partir de um conjunto de valores de parâmetros randomicamente selecionados. Os resultados das interaçōes (500 a 10 mil) são estatisticamente sumarizados. A vantagem desse procedimento é que as incertezas nas previsões do modelo podem ser baseadals em qualquer número de distribuiçōes teóricas ou empíricas especilicadas para os parâmetross do modelo. A importância do parâmetro é determinada por meio da correlação dos valores dos parâmetros randomicamente selecionados com os resultados das previsões do modelo. 
Dessa forma, a relação entre a variabilidade do parâmetro e as previsões do modelo pode ser apurada com a simples medida do coeficiente de correlação ( $r$ ). Se $r=0$, não existe relação alguma entre a variabilidade do parâmetro e as previsões do modelo. $S e r=1$ ou a -1 , existe perfeita relação positiva ou negativa entre a variabilidade do parâmetro e as previsões do modelo.

Aplicações dos procedimentos referentes ao cálculo de sensibilidade e incerteza paramétrica podem ser vistas em Hoffman \& Gardner (1983) e em International Atomic Energy Agency (1991). 


\section{REFERÊNCIAS BIBLIOGRÁFICAS}

BARnthouse, L. W. et al. User's Manual for Ecological Risk Assessment. Oak Ridge National Laboratory (Environmental Sciences Division Publication 2679), Oak Ridge, 1986. $215 \mathrm{p}$.

Bartell, S. M. Risk-Based Decision Making in Water Resource. In: Haimes,Y.Y. \& Stakhiv, E. Z. (Eds.) Ecological Risk Analysis. New York: American Society of Civil Engineers, 1992. p.224-239.

Bellia V. Apostila de aula. Curso de Gestão Ambiental. Departamento de Geoquímica Ambiental, Universidade Federal Fluminense, Rio de Janeiro, 1991.

CARdinAl, E. A. Risky business: communicating risk for the government, Environment Science Technology, 25(12):1982-1985, 1991.

Eıchноцz, G. G. Source terms for nuclear facilities, and medical and industrial sites. In: Radiological Assessment. A Textbook on Environmental Dose Analysis. In: Tul, J. E. \& Meyer, H. R. (Eds.) Washington, D.C.: Nureg/CR- 3332, Oak Ridge Natl. Lab-5968, U.S. Nuclear Regulatory Comission, 1:1-1:54, 1983.

Fernandes, H. M. et al. Risk management in environmental pollution: a case study of the uranium mining and milling facilities at Poços de Caldas, Minas Gerais, Brazil. In: Proceeding of the Latin American Section of the American Nuclear Society Symposium on Nuclear ENergy and the Environment, Rio de Janeiro, 1993.

Hoffman, F. O. \& GARDNER, R. H. Evaluation of uncertainties in environmental in radiological assessment models. In: TiLL, J. E. \& Meyer, H. R. (Eds.) Radiological Assessment. A Textbook on Environmental Dose Analysis. Washington, D.C.: Nureg/ CR-3332, Oak Ridge Natl. Lab.-5968, U.S. Nuclear Regulatory Comission, 11:1-11:55, 1983.

Hoffman, F. O. \& Hofer, E. An overview of the IAEA Safety Series on procedures for evaluating the reliability of predictions made by environment transfer models. In: DESMEr, G. (Ed.) Reliability of Radioctive Transfer Models. Elsevier Applied Science, 1988. p.1-14.

Hoffman, F. O. et al. Preliminary screening of Contaminants in the Off-Site Surface Water Environment Downstream of the U.S. Department of Energy Oak Ridge Reservation (Environmental Sciences Division Publication, 3485). Martin Marietta Energy System, Inc., Oak Ridge Natl. Lab., 1991. 
International Atomic Energy Agency (IAEA). Evaluating the Reliability of Predictions Made Using Environmental Transfer Models. Vienna, 1991. 106p. (Safety Series 100) the International Commission on Radiologicall Protection. Oxford: Pergamon Press, 1991. (Publication 60)

York, D. \& Speakman, J. Water quality impact analysis. In: RaU, J. G. \& Wooten, D. C. (Eds.) Environmental Impact Analysis Handbook. New York: McGraw-Hill Publishing Company, 6.1-6.55, 1980. 



\section{3}

\section{RISCO POTENCIAL EM \\ TOXICOLOGIA \\ AMBIENTAL}

LUIZ QUERINO DE A. CALDAS

Apesar de debridamentos culturais que por séculos vêm solapando a América Latina no pleno desenvolvimento de seu potencial humano nas áreas de ciência e tecnologia, não se pode negar que, independentemente da vontade de suas próprias lideranças sociais, informação e progresso têm alcançado distantes rincões do continente. A necessidade de esclarecimento, o crescente questionamento da opinião pública ou mesmo as dúvidas dos que exercem o poder de decisão em organismos governamentais ou não-governamentais têm contribuído cnormemente para esse impulso desenvolvimentista nas Américas: a sociedade civil defendendo seus interesses - o lazer, o trabalho, a qualidade de vida e a sobrevivência econômica acima de tudo.

Como conseqüência desta incessante busca pelo progresso, modificam-se os referenciais. Prioridades e preocupações em saúde pública sobrepassam os indicadores tradicionais do binômio saúde-doença nos diversos envelopes sociais, na medida em que estes cada vez mais se atrelam ao conccito ser-natureza, na ampla detinição que vislumbra impactos causados na biosfera. Eis que vida, sobrevivência e morte estão profundamente afetadas por variáveis biogeoquímicas ambientais que, no curso das últimas três décadas, têm alertado a comunidade sobre os efeitos antropogênicos deletérios de agentes químicos, por vezes irreversíveis, nos ecossistemas naturais.

Países em desenvolvimento, como o Brasil, têm procurado detectar precocemente esses impactos a a magnitude destas perturbações. Como consęüência, inúmeros programas e projetos que prevêem soluções práticas e economicamente viáveis têm sido aventados, na expectativa de que modelos e inferências cientilicamente úteis diminuam o erro a a incerteza destas propostas. E, desta forma, ajudem a maximizar a confiança da comunidade leiga com vistas à tomada de decisōes que envolvam a sustentabilidade com eqüidade social, ou seja, equilíbrio ecossocial sem (ou pelo menos com um mínimo de) iniqüidade.

Longevidade, hoje, significa o quanto a sociedade está dispesta a se sacrificar para eliminar ou minimizar o risco. Diante da escassez global c progressiva de recursos não há como ignorar a quantificação da certeza e da variabilidade, por hais mecanicista que seja, bem como o valor preditivo, prático e aplicado dos estudos de risco. Ainda que premalturos, 
buscam estabelecer probabilidades e custo-benetïcio de necessidades essenciais do cidadão como: o combate ao crime, a redução da miséria ou al melhoria dos sistemas de saúde e educaçño.

Em toxicologia, risco baseia-se no estudo interaivo das ciências exatas (matemátic:a/ estatística), ciências biológicas e sociais, de modo a reduzir o empirismo, as incertezas e lalhas na avaliação de toxicidade de agentes guímicos. A toxicologia ambiental, por sua vez, estuda as interaçôes tóxicas de substâncias químicas no ecossistema e sua capacidade de afetar a lisiologia normal de organismos vivos.

O risco potencial em toxicologia ambiental trata do estudo da probabilidade de fontes perigosas para a saúde e o meio ambiente, capazes de provocar dano, doença ou morte para os seres vivos quando em concentraçōes superiores àquelas que estes possam assimilar em condições normais, isto é, absorver, distribuir, melabolizar e climinar do organismo.

Quando se refere a risco e ao perigo, torma-se essencial definir a terminologia, pois comumente sĩo usados como sinônimos ou de modo inconsistente, de maneira a nāo denotar possibilidade ou probabilidade.

A uniformidade no uso destes e de outros termos é desejável, já que se trata de jargão nos compêndios e trabalhos em saúde ambiental. Assim sendo, define-se como:

- Risco: a probabilidade medida ou estimada de dano, doença ou morte causada por um agente químico $\mathrm{cm}$ um indivíduo a este exposto.

- Perigo: termo qualitativo que expressa o potencial nocivo do agente para a saúde c/ou para o meio ambiente.

- Avaliał̧ão de Risco: o primeiro passo no desencadeamento de processos decisórios, advém do conhecimento da relaçãio causa-efeito e de possíveis danos ocasionados pela exposição a um determinado agente quínico. As clapas de Avaliação de Risco também oferecem sinonímia prọpria:

- Identificação de Perigo: trata-se da identilicaçãa do agente perigoso na sua essência, scus efeitos, as condições de exposição e a população-alvo.

- Avaliação da Exposição: refere-se à quantificaçãoo da concentração do agente nocivo em um meio, para um indivíduo ou grupo.

- Estimativa do Risco: relaciona a quantificação da relação dose-resposta ou dose-cleito para um daclo agente ambiental, demonstrando a probabilidade e a natureza dos seus efeitos na saúde e no meio ambiente.

- Exposição ou Dose: tratiı da delinição quantitativa da concentração de substância química que atingiu (dose extema) o indivíduo ou daquela que foi absorvida (dose interna) por ele. 
- Caracterização do Risco: trata-se đa reunião das etapas anteriores que, de posse de todos os dados disponíveis sobre o assunto, caracteriza o uso específico ou a ocorrência de dano, doença ou morte provocada por exposição a deter minada concentração de agente químico.

- Gerenciamento ou Gestão de Risco: assim concebido, refere-se à comparação do risco calculado ou dos impactos para a saúde pública, da exposição ambiental an agente, bem como a possível constribuição de fatores sociais e econômicos que incluem também os benefícios associados a estes. Em última análise, neste processo, pode-se estabelecer que perante as condições propostas, o risco pode ser aceitável.

Outro aspecto de grande relevância para o estudo do risco refere-se à percepção da existência do risco químico pela população leiga. Ainda que as preocupações relativas à saúde façam parte de nossas vidas desde tempos imemoriais, só recentemente têm sido evidenciadas mudanças significativas nas atitudes e na aceitação do risco. Durante o processo evolutivo, os organismos tiveram de se adaptar e se ajustar a agentes químicos endógenos $\mathfrak{e}$ exógenos na luta pela sobrevivência entre espécies. Até os mais evoluídos sofreram um processo de seleção natural $\mathrm{e}$ adaptações fissiológicas que concorreram para o aperfeiçoamento de sua interação com o meio ambiente que os cerca. O homem, além disso, vem desenvolvendo, ao longo do tempo, padrões culturais e de comportamentos que minimizam ou mesmo evitam a exposição a agentes químicos nocivos. Tais ajustes têm despertado a consciência crítica de dirigentes e autoridades que não consideram o risco como fator inevitável.

Pratt \& Zeckhauser (1994), em interessante exercício econométrico, discutem sobre o desejo individual e coletivo de cidadãos desembolsarem de suas próprias economias para reduzir o risco. Mostram que esta vontade depende de quão enraizado o risco pode estar no seio populacional, do grau desse risco e da magnitude de redução do risco (intervenção) oferecida por cada centavo desembolsado. Para tanto, demonstram (Gráfico 1) que, quanto maior é a lraçãao de redução do risco $(0,25)$, maior será o custo linal para o grande público, mas que, nāo necessariamente, isto abala a vontade de desembolsar de suas economias para evitar o risco. Entretanto, quando a fração de risco reduzido traz soluções íntimas ao problema $(0,1)$, não apenas eleva a quantia a ser dispendida pelo segmento mais exposto como também reduz o desejo do desembolso. Situações intermediárias $(0,16)$ conscientizann apenas o segmento da população mais próximo ao problema $(1,37 \%)$, ou seja, ocorre uma nítida tendência ao comportamento individualista. 

0.01 per capita)

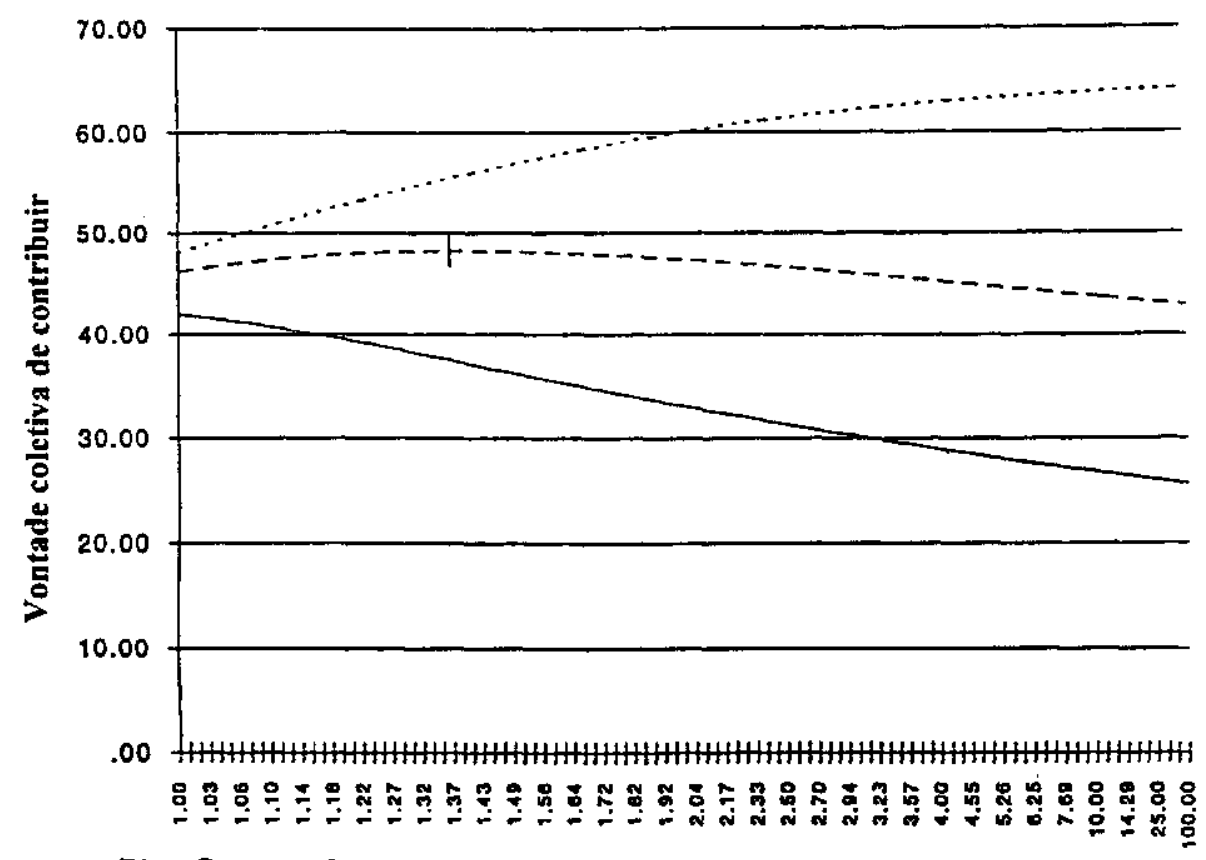

Risco Concentrado Porcentagem de Contribuintes Risco Disperso

Fração de Risco

Reduzida

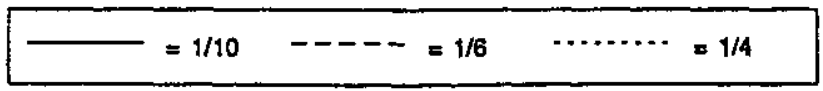

Fonte: Adaptado de Pratt \& Zeckhauser (1994).

Fatores contribuintes para a percepção do risco químico pelas populações têm sido as campanhas de protesto de organizações não-governamentais contra os danos ecológicos e humanos causados pela exposição a agentes declaradamente nocivos à saúde.

A consciência ambiental desses grupos está além das expectativas do público leigo no que tange à poluição do ar, solo e água. Refere-se também à contaminação ambiental por lixo nuclear, ruídos e resíduos industriais. Pesticidas têm despertado uma atenção especial, bem como xenobióticos de persistência prolongada e, conseqüentemente, danosa para o meio ambiente, tais como: organoclorados, metais pesados, clorofluorcarbono etc.

Acidentes de grandes proporções têm aguçado o interesse público na proteção das comunidades. Dentre os desastres ecológicos de grandes proporções, pode-se assinalar a contaminaçăo de Seveso, Itália, por dioxina; o acidente da Baía de Minamata, Japão, por $\mathrm{Hg}$; a contaminação de rios amazônicos por metais pesados como $\mathrm{Hg}, \mathrm{Cd}$ e $\mathrm{Pb}$, entre outros; as contaminações em Michigan, nos EUA, e em Formosa, na China, por bifenilas 
poli-halogenadas (PCBs); e no Brasil, a ampla contaminação da 'Cidade dos Meninos' - no bairro de Duque de Caxias, Rio de Janeiro, por toneladas de hexaclorociclohexano técnico.

Esses incidentes têm servido para impor mudanças substanciais na visão conservadora da sociedade, no que diz respeito aos métodos e processos da obtenção, utilização e disposição de produtos químicos. Mesmo porque, estudos têm demonstrado os perigos dos efeitos retardados na saúde desses agentes, tais como: doenças genéticas e câncer por exposição prolongada.

A Avaliação de Risco Químico-Tóxico tem sido crucial para assegurar a qualidade de vida no ambiente. Vários países vêm utilizando a Avaliação de Risco para substâncias químicas produzidas ou importadas, na tentativa de minorar o impacto do desenvolvimento industrial na saúde e nos ecossistemas.

\section{Classes do Risco}

A Avaliação de Risco não é uma nova ciência. Há décadas vem sendo utilizada por companhias de seguro, na proteção de carregamentos transportados por veículos e embarcações de carga, na expectativa da ocorrência de acidentes naturais, colisões, abalroamentos, entre outros, que possam danificar ou fazer perecer o material segurado. Tais avaliações são relativamente simples mesmo que envolvam risco de vida, ou seja, baseado na experiência de atuários pode-se prever, com razoável grau de certeza, as falhas, erros, vítimas (inclusive) e acidentes que, porventura, venham ocorrer com esses carregamentos, baseado em experiências acumuladas pertinentes às rotas $\mathrm{e}$ desvios de percurso que aconteceram em situaçōes anteriores.

Na realidade, o resultado da Avaliação de Risco de um determinado evento está nas apólices de seguro diretamente relacionadas com o prêmio a ser pago pelo beneficiário, $\mathrm{e}$ este com a magnitude do evento. Atualmente, os riscos não são caracterizados apenas para os bens materiais; outras classes podem ser incluídas, como apresentado a seguir:

- Risco para pessoas: refere-se ao risco intencional, ou não, de protissões ou atividades perigosas ou insalubres que venham a infligir algum tipo de doença, lesão ou mesmo morte daqueles que estão expostos a estes. Parte daí a idéia de se fazer um seguro especial de parte do corpo humano de 'maior' valor para o beneficiário. Por exemplo, as mãos dos pianistas e cirurgiōes, as pernas dos bailarinos, a audição dos afinadores de instrumentos de corda, ou por outro lado, a própria vida dos submarinistas, escafandristas, entre outros.

- Risco para o ambiente: trata do ativo e do passivo ambiental ante a contaminação, poluição, degradação ou devastação dos recursos naturais e dos ecossistemas. Como exemplo,temos a emanação de gases e vapores perigosos ou tóxicos por indústrias; a contaminação de mananciais por pesticidas ou metais pesados; o efeito estufa por combustăo de derivados de petróleo. 
- Risco para bens materiais: relere-se à probabilidade da ocorrência de eventos inesperados, cujos custos são estimados ou perdas contabilizadas no valor total do seguro. Por exemplo: seguro de veículos e cargas; contra incêndios, roubos e furtos; em casos de corrosão de pontes e edifícios; nos eventos naturais, como sismos e maremotos.

Na classe de risco para pessoas existe um fator preponderante que pode determinar o aumento ou diminuição do grau do risco no evento: o fator humano. Assim, poder-se-ia condicionar a ocorrência do fenômeno à volição, ou seja, ao ato determinada ou não pela vontade do homem.

A classe de risco para pessoas deve então englobar:

- O riseo voluntário: decidido pelo livre arbítrio do indivíduo, ou seja, um riseo intencional calculado (extração de minérios, jateamento de areia etc.).

- O risco involuntário: onde o indivíduo não sabe o que está acontecendo, não tem consciência do perigo ou não foi intormado sobre o assunto (trabalhar ou morar em áreas extremamentes poluídas, pessoal de escritório que executa atividades em plantas industriais insalubres etc.).

Existe ainda um risco que não é percebido ou sentido, mas que pode se revelar altatmente perigoso no momento em que se prenuncia: é o chamado risco potencial (galão de combustível bem acondicionado, cápsula intacta contendo microorganismos de alta virulência etc.).

A Gestão de Risco trata do processo decisório que leva em consideração fatores como: Avaliação de Risco, facilidade tecnológica, relação custo/benelício e custo/efetividade, preocupaçōes do público e outras atitudes eminentemente políticas.

Para entender melhor a magnitude do evento considerado arriscado ou perigoso, é necessário montar cenários específicos que possam descrever as circunstâncias pelas quais os objetos (biológicos ou não) possam estar expostos a esses riscos (por exemplo: poluentes ou contaminantes). Esses cenários freqüentemente formam a base necessária para a padronização, regulamentação e avaliaçāo do risco específico. Eles podem ser compostos de uma ou mais vias de exposiçāo e, por conseguinte, utilizados para estimar graus de exposição a agentes. Algumas inlormaçōes podem ser essenciais para se estabelecer o desenho completo de um cenário, yuais scjam, entre outras:

- Lonles de perigo (ascarel armazenado cm tambores de latão, por exemplo);

- fatores de deflagração (tambores contendo ascarel expostos ao tempo, por exemplo);

- transponte e tauns formação (capacitores com ascarel submetido a alas temperaturas $>1.0(0)$ " $\mathrm{C}$, por exemplo); 
- exposição humana (comunidade leiga com acesso a tambores contendo ascarel, por exemplo);

- ingestão ou captação (fugas, derrames ou utilização de ascarel contaminado em domicílios, por exemplo);

- fatores de confundimento (por exemplo, relativo ao ambiente: latões contendo ascarel depositados em vazadouros ou em área contígua a zonas industriais; relativo ao homem: tabagismo, etilismo, exposição a pesticidas clorados etc.).

\section{Toxicogênese de Substâncias Perigosas}

Acumulam-se as evidências de que os fatores ambientais que determinam a higidez dos ecossistemas vêm gradualmente sendo modificados. Entretanto, são escassos os relatos sobre as alterações que tais fatores tenham determinado os níveis de correlação entre essas mudanças e a deterioração da saúde do ecossistema. Não obstante, existem fortes suspeitas sobre os xenoquímicos bioacumuláveis que continuam se depositando nas diversas matrizes bióticas e abióticas.

O possível resultado que o homem compartilha, no momento, com a natureza, é a progressiva redução do número de espécies vivas que até então não tinham expectativa de extinção eminente, assim como em contrapartida o ressurgimento de enfermidades por agentes biológicos que já se considerava sob controle, a superpopulação ou mesmo a proliferação de microorganismos nunca anteriormente identificados em áreas de colonização recente (Platt, 1995; Couto, 1996). Na realidade, trata-se de uma readaptação das espécies às contingências resultantes notadamente do estresse químico do ambiente, ou seja, uma contenda de sobrevivência ao desaparecimento da simbiose química com o ecossistema.

Como as condiçōes de desequilíbrio dependem basicamente da quantidade, da duração e da intensidade da exposição aos xenoquímicos, mais cedo ou mais tarde se haverá estabelecido a etiologia química e as respectivas relações dose-respostas dessas interações na procura do nexo causal de tais extinções. Restringindo a discussão a substâncias químicas, poder-se-ia inferir que essas alterações são de origem essencialmente antropogênica e intimamente relacionadas às emissões de grande quantidade de contaminantes no ar, mananciais, aqüíferos, além de aditivos tóxicos nos alimentos e em solos cultiváveis, a disposição de dejetos urbanos perigosos não-degradáveis, a excessiva combustão da biomassa (carvão, madeira e petróleo) e o desenvolvimento industral desenfreado.

O risco potencial de alimentos, água, ar e solo contaminados por xenoquímicos são as causas mais comuns de doenças de etiologia ambiental (Craighead, 1995). O caminho que conduz ao aparecimento de modificações subclínicas nas populações expostas, doença (morbidade) e casos fatais (mortalidade) são apresentados na Figura 1 (Vaca-Mier \& Caldas, 1995). 
FIGURA 1 - O algoritmo da saúde ambiental: marco conceitual individual

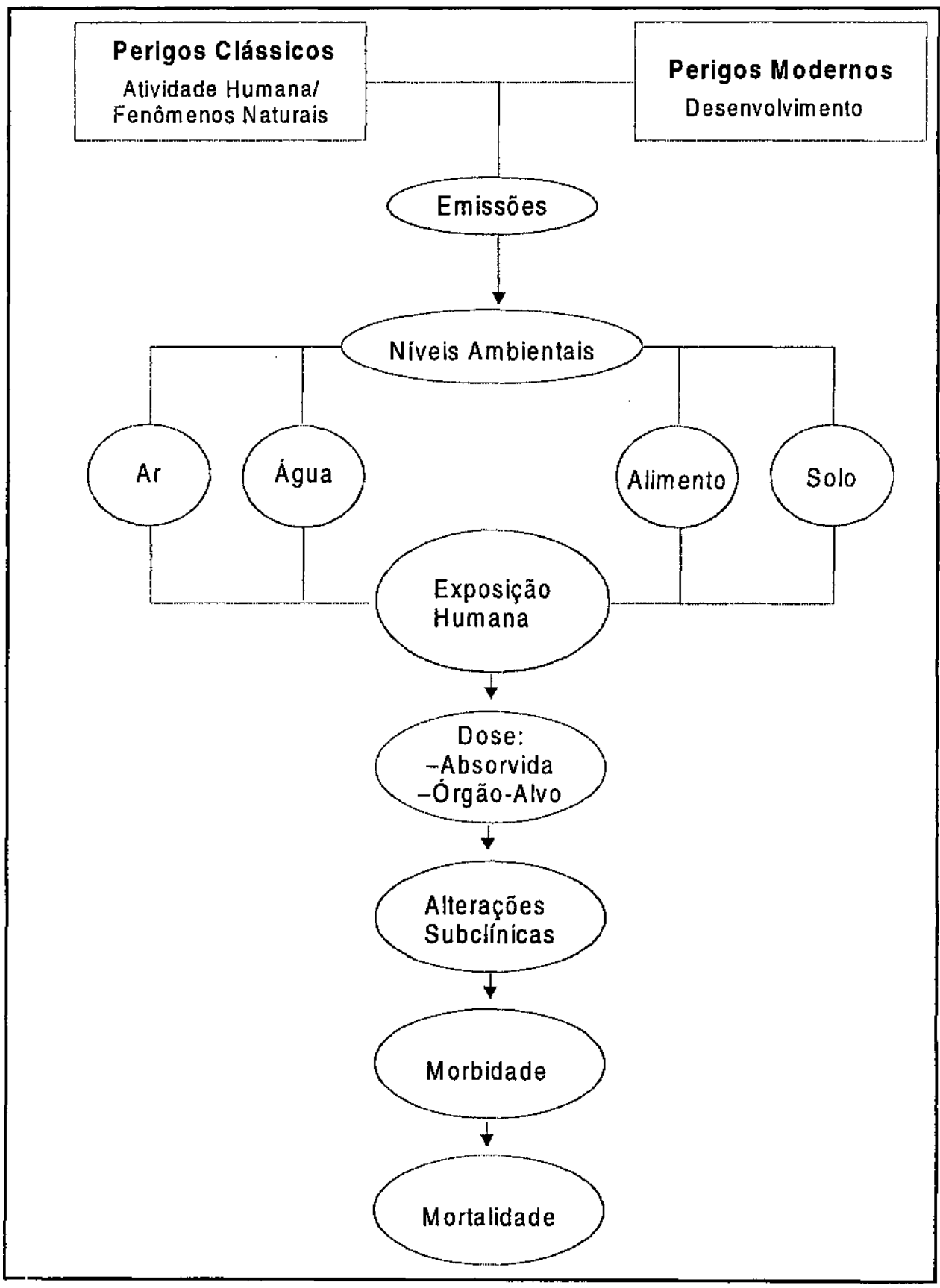


A despeito de muitos estudos em toxicologia terem demonstrado que, com algumas exceções, quase todos os xenoquímicos são inócuos quando dissolvidos no meio em quantidades iguais ou próximas à relação $1: 10^{9}$, ou seja, aproximadamente $1 \mathrm{ppb} \mathrm{e}$, por conseguinte, as interações tóxicas são improváveis, os modelos de Avaliação de Risco podem demonstrar, por extrapolação, que tais quantidades podem ocasionar danos irreparáveis ao organismo. Por exemplo, a ingestão diária de 1 litro de água potável tratada por meio da cloração (Yang, 1994).' O autor postula elegantemente que, no universo de moléculas, o espectro capaz de produzir êxito letal de uma célula ou tecido é extremamente pequeno quando comparado com os métodos usuais de análise das curvas dose-resposta/dose-efeito. Traduzindo e adaptando a curva dose-resposta apresentada pelo autor, ou seja, transformando-a em curva logarítmica do número de moléculas versus a resposta máxima observada (morte), incluindo doses tóxicas e letais, a escala de magnitude da curva sigmóide, de inclinação bastante pronunciada, parece desprezível, ainda que seja $10^{3}$ ou $10^{4}$ vezes maior que a dose onde há ausência completa de efeitos (convencionalmente denominada de NOEL. - No Observed Effect Level) (Grático 2). Neste caso, a resposta à dose molecular média $\left(\mathrm{RM}_{50}\right)$ produzida por um agente como o clorofórmio seria de $5 \times 10^{16}$ moléculas, ao passo que a resposta letal seria obtida com doses moleculares de $1 \times 10^{18}$. Proporcionando tais valores ao número de células do organismo humano de um adulto de $70 \mathrm{~kg}$, seria plausível imaginar que a dose letal seria de $10^{2}$ a $10^{3}$ moléculas de clorofórmio por célula. Isso vem confirmar a vulnerabilidade biológica dos sistemas a substâncias xenoquímicas, que, confrontadas com as halobióticas (como o ferro), deveria ter uma dose letal de $10^{4}$ a $10^{5}$ moléculas do metal por célula (Gosser \& Bricker, 1994).

O espectro previamente mencionado pode ser reduzido drasticamente $\left(10^{1}\right.$ a $\left.10^{2}\right)$ pela presença de misturas químicas múltiplas, ou seja, quantidades minúsculas destas substâncias em associação podem desenvolver ações sinérgicas e/ou complementárias provocando efeitos intensos diversos nos sistemas biológicos (Kligerman et al., 1993).

Teoricamente, por exposição ambiental múltipla pode-se observar a superposição de efeitos tóxicos. Por exemplo, curvas teóricas concentração-resposta que demonstram a toxicidade de metais pesados ( $\mathrm{Pb}, \mathrm{Hg}$ e As) no sistema nervoso central de humanos (Gráfico 3). Onde o logaritmo da concentração sangǘnea $(\mathrm{mg} / \mathrm{dl})$ foi plotado, versus a porcentagem de toxicidade obtida até o êxito letal. Neste caso, o risco torna-se proporcional ao número de agentes químicos, modo de ação, dose absorvida, interação com o sistema biológico, entre outros.

\section{Convivendo com o Perigo}

Ações regulamentadoras como aquelas preconizadas nos Programas de Prevenção de Riscos Ambientais (PPRA), adotadas pelo Ministério do Trabalho em 1995, mesmo que preambulares, são de imensa importância no desenvolvimento das ciências do risco. Enquanto a Avaliação de Risco Tóxico trata de analisar as características pelas quais os agentes químicos e as condições de exposição humana podem determinar a probabilidade pela qual estes

Ver adiante exemplo relatado por Jo, WeISEL \& LiOY (1990). 
GRÁFICO 2-Curva teórica dose molecular-resposta mostrando a toxicidade do clorofórmio (em \%) versus o número de moléculas do composto $\left(\mathrm{RM}_{50}\right)$

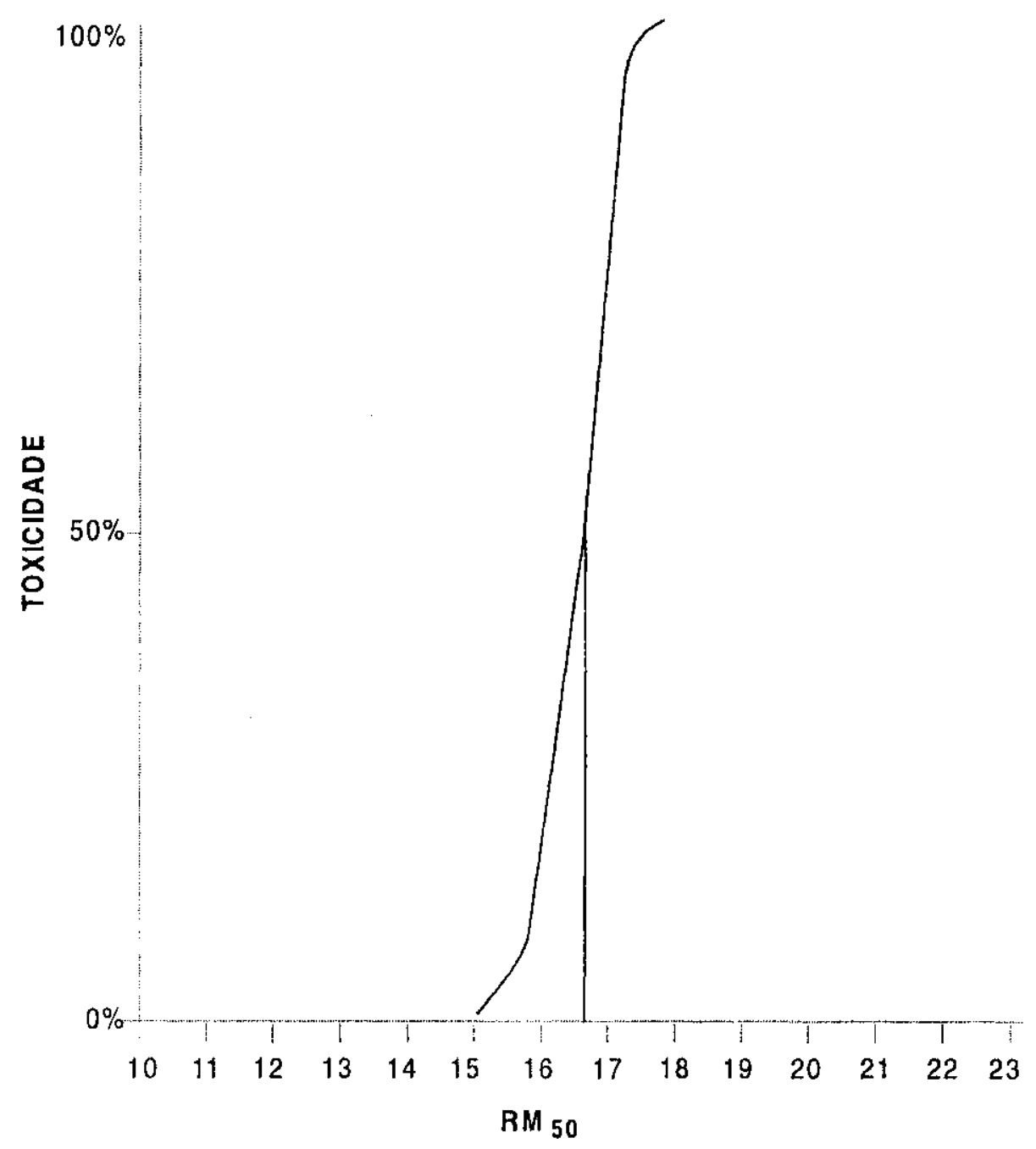


GRÁFICO 3 - Curvas teóricas dose-resposta cujo máximo corresponde a dano irreversível (morte) provocada por chumbo $(\mathrm{Pb})$, mercúrio $(\mathrm{Hg})$ e arsênico (As). As doses iniciais entre 0 e $1 \mu \mathrm{g} / \mathrm{dl}$ não prenunciam quaisquer disfunções neuropsicológicas

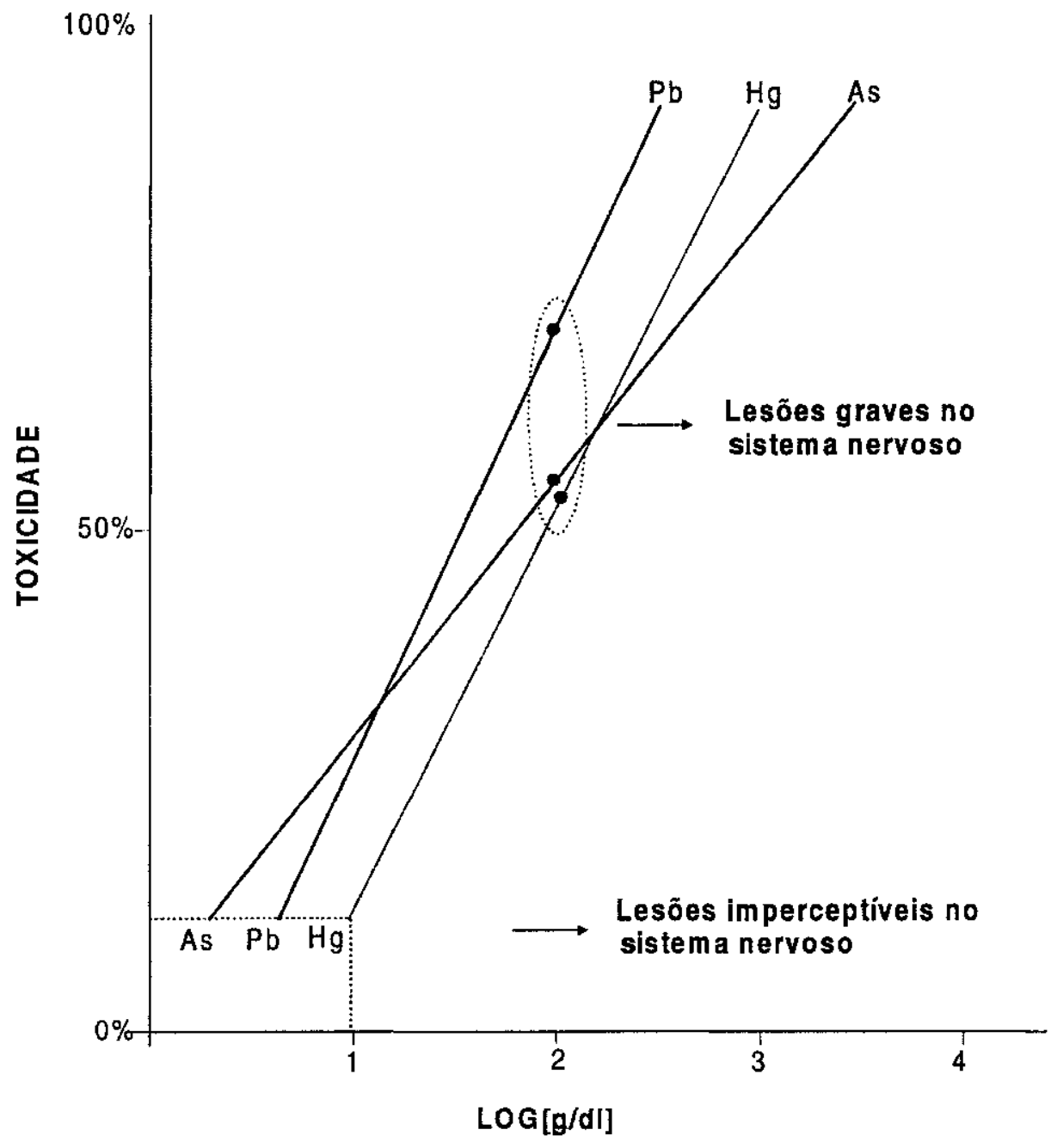


possam ser deleteriamente afetados, o gerenciamento do risco é o processo em que se determina a medida mais adequada para controlar ou eliminar o risco. É o que se pretende com programas singelos como esses, mas de grande alcance social.

Nos países em desenvolvimento, onde a aplicação desses conhecimentos é bastante escassa, medidas de intervenção quase sempre resultam em ações drásticas, sensacionalistas e, em geral, impróprias para lidar com o problema, fortemente determinadas por indicadores sociopolíticos do período em questão. Com frequêencia, permitem-se níveis de exposição/contaminação bem acima daqueles reconhecidamente inócuos à saúde da população. Em muitas circunstâncias, por exemplo, a descontaminação de sítios com resíduos perigosos é bem menos rigorosa do que a necessária para preservar os recursos ambientais disponíveis, uma vez que os próprios moradores da área se acostumaram a conviver com o perigo. No Quadro 1, apresentamos uma lista de resíduos considerados perigosos. Com muitos, as comunidades convivem diuturnamente sem se aperceberem ou mesmo se incomodarem com o risco potencial que representam.

\section{QUADRO 1 - Lista de produtos ou agentes selecionados considerados residuos perigosos}

1. Produtos sem especificação

2. Produtos fora de validade

3. Sobras e perdas de materiais

4. Solo ou material contaminado

5. Materiais em desuso (solventes contaninados)

6. Resíduos de processo industrial (granalha)

7. Resíduos recolhidos de áreas contaminadas

8. Resíduos de processos de produção

9. Resíduos de materiais brutos ou inacabados

10. Materiais adulterados (PCBs+óleo diesel)

11. Materiais proibidos por lei

12. Materiais inúteis (agrícola, escritório etc.)

13. Materiais ou produtos contaminados
14. Explosivo

15. Oxidante (reação exotérmica)

16. Corrosivo

17. Inflamável

18. Irritante

19. Nocivo à saúde

20. Tóxico

21. Carcinogêniço

22. Infeccioso

23. Teratogênico

24. Liberador de gases tóxicos

25. Lixivias

26 Substâncias ecotóxicas para um ou mais ecossistemas

Fonte: Vaca-Mier \& Caldas (1995). 
Dependendo do grau de ignorância científica, os resultados dè uma Avaliação de Risco são desprovidos de qualquer importância ou mesmo interesse para as comunidades afetadas, na sua capacidade de lutar por melhor qualidade de vida, ou seja, medida preventiva (precatória) por demanda pública efetiva capaz de manter ou reduzir a incidência/prevalência de doença, dano, lesão ou morte provocadas por exposição a agentes perigosos.

Entretanto, Kelly \& Cardon (1994) fizeram vários questionamentos sobre a origem e definição de risco aceitável para populações humanas, conjecturando as bases científicas que levaram as agências governamentais a estabelecerem que o risco para a saúde humana é a chance de, por exemplo, um indivíduo em um milhão (1:1.000.000) desenvolver câncer ao longo de sua vida, em decorrência da ingestão de certa quantidade de alimento contendo pesticida ou aditivo alimentar sabidamente carcinogênico. Na opinião das autoras, um risco de 1 mil a 100 mil vezes inferior à probabilidade de adquirir câncer por todas as outras causas. Ainda em se tratando de contaminação ambiental, alimentar e ocupacional, a possibilidade de se atingir o risco 'essencialmente zero' $\left(10^{-6}\right)$ é virtualmente implausível e economicamente inviável. Para as pesquisadoras, seria o mesmo que considerar que somente a velocidade de $1,6 \mathrm{Km} / \mathrm{h}(1 \mathrm{milh} / \mathrm{h})$ seria aquela virtualmente segura e aceitável para que não ocorram mortes por acidente automobilístico em rodovias, levando-se em consideração a relação custo-benefício embutida no conceito de tráfego automotriz.

Ainda que conservadores, esses níveis de riscos (1:1.000.000), largamente utilizados por agências regulamentadoras internacionais, têm sido objeto de constantes reavaliações, e as extrapolações, cuidadosamente redimensionadas por tomadores de decisão que têm a intenção (muitas vezes relutam) de aplicar tais limites para implementar aleatoriamente normas e decretos com esta finalidade.

Em síntese, pode-se dizer que a Avaliação de Risco tornou-se importante instrumento para a identificação do Risco Potencial de agentes (químicos, físicos ou biológicos) nocivos à saúde da população, para a formação de políticas públicas e regulatórias, bem como para o estabelecimento das prioridades de combate dimensionadas a estes agentes, seja na área pública ou privada, com implicações econômicas inequívocas nos processos decisórios a que estão sujeitos. Tais considerações têm, em geral, suscitado acalorados debates sobre o tema, por vezes pondo em dúvida a credibilidade dos métodos e medidas propostas. Tratase de um assunto em plena ascenção, nos meios científicos, que merece destaque nos processos 'modelados' de desenvolvimento sustentável para países do Terceiro Mundo.

\section{A Relação Dose-Resposta}

Para cada substância química existe um espectro de doses para as quais não se consegue identificar manifestações de toxicidade em pessoas expostas. Porém, quando esse é extrapolado, efeitos tóxicos começam a aparecer, com gravidade e freqüência dose-dependentes. Agentes químicos diferem muito entre si na sua dose-resposta característica. Se consideramos unidades de medida em ordem de grandeza proporcional ao micrograma $(\mu \mathrm{g})$ ou mesmo ao micromol ( $\mu \mathrm{mol})$, comportam-se de igual maneira em termos físicoquímicos, porém bastante diversa em termos de potência e eficácia, em diferentes espécies 
animais, sob as mesmas condições de teste, ainda que todos possam desencadear o mesmo tipo de fenômeno.

Por mais abjeto que seja, somente a partir da avaliação das características da relação dose-resposta consegue-se entender quais os riscos para a saúde que tais substâncias causam. Significa dizer que para cada uma delas, se conhecemos o espectro de doses consideradas inócuas e, por conseguinte, onde e como os eleitos tóxicos se iniciam, torna-se possível prevenir exposições que sejam capazes de desencadear efeitos deletérios no organismo.

Todavia, especialistas em Avaliação de Risco Toxicológico se encontram bem distantes destes objetivos. A começar pela escassez de dados sobre dose-resposta e toxicidade, disponíveis apenas para uma reduzido número de agentes químicos. Para nosso contentamento, a grande maioria de substâncias manutaturadas para uso como medicamentos, pesticidas, aditivos alimentares e para outros propósitos industriais têm essas características bem delineadas, ao contrário do que acontece com dezenas de milhares de produtos de consumo diário ou mesmo componentes naturais de nossa dieta.

Assim, se faz importante lembrar que uma das molas propulsoras da toxicologia como ciência foi justamente aquela que originou as preocupações com a saúde dos trabalhadores pela exposição a vários toxicantes gerados pela revolução sem precedentes na indústria química.

Associe-se a isto a regulamentação normativa que introduziu a obrigatoriedade de avaliação de toxicidade de muitas dessas substâncias, antes que estas estejam disponíveis para comercialização. No entanto, o mesmo não acontece na área de substâncias de origem natural, além do que também seria incorreto afirmar que conhecemos profundamente a toxicogênese das substâncias já estudadas.

A documentação disponível revela que estamos muito mais próximos do empirismo đo que da validação científica, ou seja, mesmo para substâncias mais conhecidas sāo ainda bastante incertos os espectros de ação onde se pode declarar com razoável certeza as doses seguras e inseguras de exposição. Por mais inusitado possa parecer, mas este seja talvez o principal motivo para que haja compreensão do valor, ou que justifique uma Avaliação de Risco Toxicológico.

Cabe aqui uma breve explicação do grau de importância dado à representação gráfica (geralmente uma curva) da relação dose-resposta. Como toxicologistas, acreditamos que quanto mais diversificada for a informação a respeito do produto (categoria e tipo de toxicidade, por exemplo), maior será o conhecimento sobre seus efeitos deletérios na físiologia do organismo.

Especialistas em Avaliação de Risco, por outro lado, gostariam de ter em mãos resultados ligados a espécies tão nobres quanto os seres humanos, de preferência por diferentes vias de exposição, de modo a inferir gravidade à exposição, mesmo por pequenas quantidades do agente.

Não se deve esquecer de ressaltar a prudência em avaliar em detalhes quaisquer extrapolaçōes feitas a partir das curvas dose-resposta, uma vez que a grande maioria das informaçōes científicas obtidas advém de investigações epidemiológicas e estudos experimentais realizados em animais de laboratório. E, tanto no primeiro quanto no segundo caso, 
relatos sobre o binômio dose observada-resposta esperada são bastante imprecisos sob o ponto de vista preditivo (para seres humanos).

Entretanto, com o franco desenvolvimento científico, esta possibilidade se torna cada vez mais próxima. Em alguns casos, já se consegue obter a concentração de substâncias e seus metabólitos em fluidos biológicos e tecidos-alvo, de modo a designar sua real atividade intrínseca, isto é, repercussões clínicas no objeto biológico. Exposiçāo ou dose externa (em $\mathrm{mg} / \mathrm{m}^{3}$ ou $\mathrm{mg} / \mathrm{kg}$ de peso/dia) de chumbo, por exemplo, não se constitui hoje um bom indicador do grau de risco como o que se verifica usando a fluorescência de raios $\mathrm{X}$ de tecido ósseo (XRF) para detectar a deposição de $\mathrm{Pb}$ (dose interna) ao longo da vida (Wedeen et al., 1995), mesmo com as atuais limitações da técnica.

Por sua vez, geram bastante controvérsia as respostas tóxicas esperadas. As do tipo 'tudo-ou-nada', isto é, dicotômicas ou descontínuas, que se traduzem na incidência de toxicidade em uma grande variedade de eventos clínicos ou experimentais, e as respostas contínuas, que espelham a severidade do quadro de intoxicação ante as doses simples de uma substância. Em nenhum dos dois casos há o risco potencial dos agentes envolvidos, ou seja, não se deve confundir toxicidade com risco. Como exemplo do primeiro caso, temos o efeito tumorigênico da 2-naftilamina, que pode provocar câncer de bexiga em trabalhadores da indústria têxtil ou em animais de experiência, e, no segundo, a toxicidade hepática do tetracloreto de carbono que, de acordo com a dose, vai progressivamente degenerando o parênquima até a completa morte celular. Nas duas situações o risco de câncer existe, mas não necessariamente em conseqüência da exposição aos produtos.

Um bom exemplo é o que se refere à ingestão de bebida alcoólica, no qual até um determinado nível sérico, torna-se factível afirmar que uma pessoa não esteja sentindo absolutamente nada, porém, quando certo limite é ultrapassado (variando de indivíduo para indivíduo), esta se apercebe que está sob a influência dos efeitos inebriantes próprios do álcool. Ainda que estes efeitos não sejam nitidamente detectados, é bastante provável que quando se passa a ser usuário crônico, cedo ou tarde desenvolver-se-á um grave quadro de degeneração gordurosa do fígado. Existem inúmeros exemplos de tolerância ao agente, entretanto, sabidamente uma tração da população tem um 'limiar' que parece estar íntima e quimicamente relacionado ao desenvolvimento da doença (cirrose hepática).

Esta abordagem sobre patamares de resposta da curva dose-efeito caracteriza o que se convencionou chamar de NEL (No Effect Level), NOEL. (No Observed Effect Level), NOAEL (No Observed Adverse Effect Level) e FEL (Frank Effect Level) (Gráfico 4), acrônimos adotados da língua inglesa. ${ }^{2}$

Dentre esses, o NEL foi praticamente desprezado, pois significa ausência completa de efeito de uma substância. Não se pode inferir que uma determinada dose seja absolutamente desprovida de efeito. $O$ argumento de contestação é que os intrumentos disponíveis de detecção e medida foram incapazes de perceber, até o momento, qualquer alteração no objeto biológico.

2 Para mais detalhes, ver capítulo 4 e glossário. 
Em ambos casos, a porção da curva que estabelece a transição efeito tóxico e nãotóxico é tecnicamente chamada de 'limiar', mas na realidade trata-se de um conceito virtual, pois se há que provar a existência de efeito anterior ao que foi demonstrado como ausência de resposta, o que torna o pleito cientificamente contestável (Grático 4).

GRÁFICO 4 - Curvas dose-resposta diagramadas para demonstrar os diversos segmentos da resposta proporcionais à dose administra da. Assim, DRf significa dose que, levando-se em consideração fatores de incerteza (FI) e fatores modificadores (FM), não impōe risco à populaçāo. Enquanto as demais referem-se àquelas nas quais os efeitos não são observados (NOEL), onde efeitos adversos não são observados (NOAEL), apenas alguns efeitos adversos nāo são observados (LOAEL) ou quando estes são francamente observados (FEL)

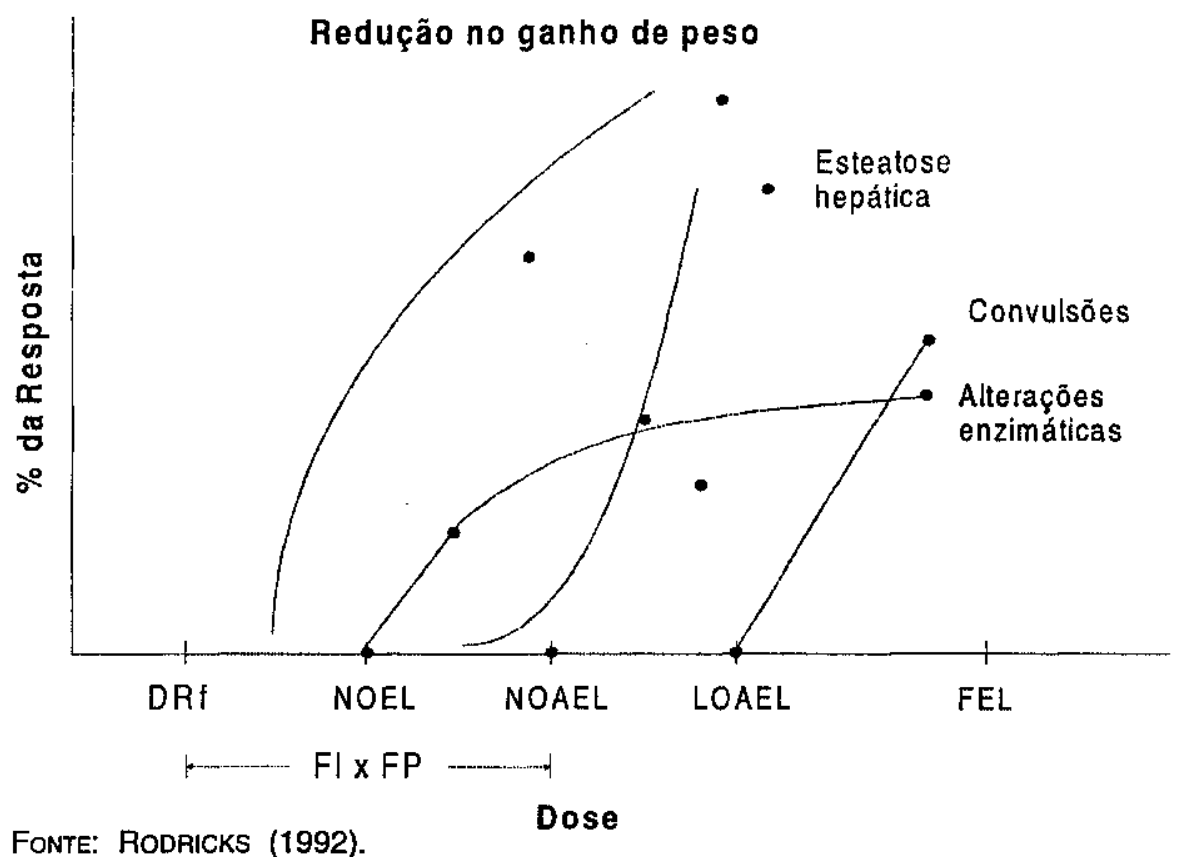

O NOEL admite esta possibilidade quando insere o conceito de 'observado', ou seja, não foram notados os efeitos em uma determinada dose, mas é provável que existam (é bom lembrar que a grande maioria de resultados destas curvas são obtidos de um número limitado de animais de experiência e de dados epidemiológicos com ampla margem de confundimento). Mesmo porque, curvas dose-resposta/dose-efeito típicas geralmente desprezam estatisticamente os resultados apontados nos seus extremos. Isto significa que quando os mesmos se distribuem normalmente, $4,6 \%$ dos dados que se agrupam nos extremos da curva ( $2,3 \%$ em cada lado) não têm significado estatístico para um determinado evento, estudado na maioria da populaçāo. 
O NOAEL contempla o conceito de 'adverso', e desta forma também a capacidade metabólica e/ou regenerativa do organismo de não deixar que ocorram danos celulares antes que as concentrações esgotem a habilidade de reparo das células ou tecidos.

O Flé é um nível de dose ou concentração que admite uma resposta ou efeito 'aberto' (franco) dà substância.

Todos estes conceitos implicam afirmar que na realidade não existem limiares, mas sim Iimitações na capacidade de deteç̧ão ou medida de eventos biológicos, ou seja, o risco persiste até que a dose ou concentração do xenobiótico decaia para zero. Henrion \& Fischofr (1986) demonstram, no Gráfico 5, exatamente a variação (leia-se incerteza) observada na medida da velocidade da luz no curso do último século c, ainda, que menos de 50\% dos limites estabelecidos incluíam os valores atuais no cálculo da variação do erro. Porém, algumas controvérsias fora do escopo deste texto podem ser identificadas em tais conceitos.

\section{GRÁFICO 5 - Valores de referência da velocidade da luz recomendados para diferentes ocasiōes ao longo deste século e respectivas incertezas}

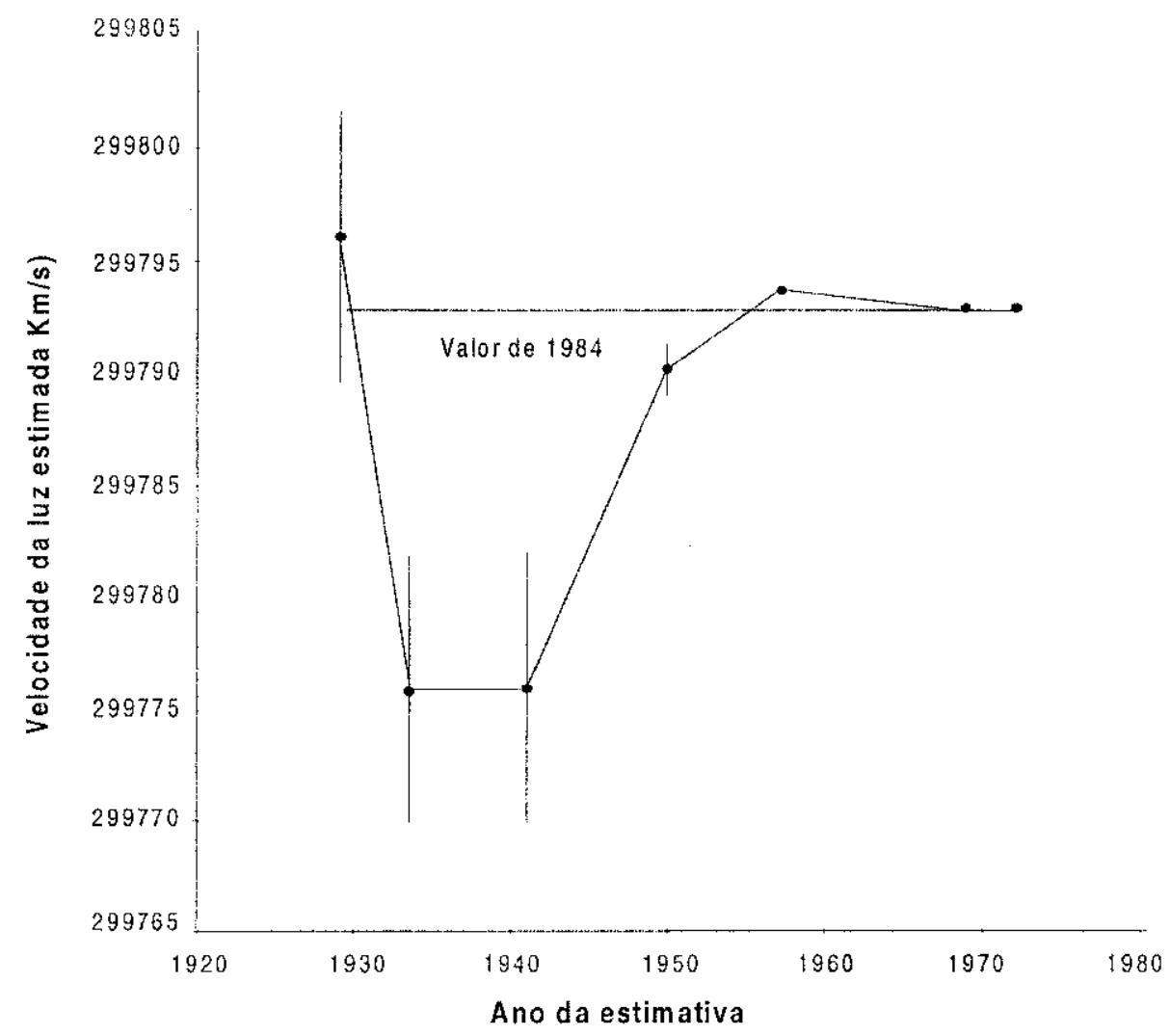

FONTE: HENRION \& FISCHOFF (1986). 
Rodricks (1992) busca demonstrar, utilizando curvas dose-resposta hipotéticas (Gráfico 6), o comportamento de efeitos limiares e não-limiares em modelos que teoricamente representam a probabilidade de se adquirir câncer, induzido ao longo da vida, por exposição a doses mínimas de uma substância. Nesta situaçāo, considerou como risco tolerável aquele em que se obtém apenas um único caso desta doença em uma população de $100 \mathrm{mil}$ pessoas, ou seja, uma probabilidade 10 mil vezes menor que aquela observada para o valor mínimo de risco estimado para testes com animais inteiros.

GRÁFICO 6 - Curvas hipótéticas dose-resposta no qual se postula o efeito carcinogênico quimicamente induzido, mostrando três curvas oriundas de três estudos (respostas observadas), o limiar teórico e três outras na região dose reduzida-risco reduzido para demonstrar as possibilidades de extrapolação

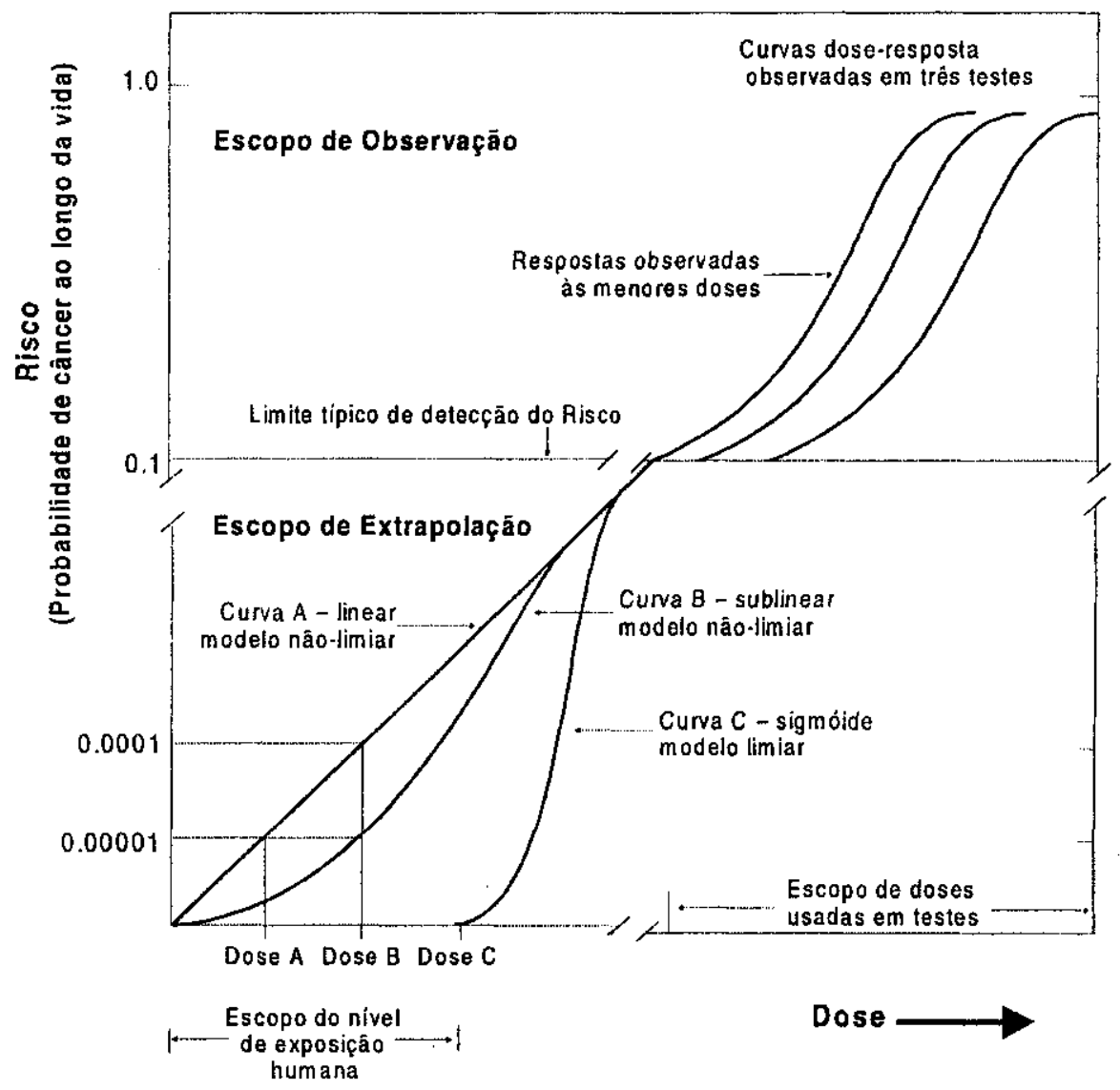

FonTE: Adaptado de RODRICKs (1992). 
Assim, utilizando-se diferentes modelos, observam-se importantes variações de acordo com as extrapolações permitidas por determinado modelo. No caso da curva $\mathrm{C}$, por exemplo, somente uma dose três ordens de magnitude superior seria capaz de induzir câncer com o risco de 0.01 , ou seja, aproximadamente mil vezes inferior à dose correspondente ao risco tolerável utilizando-se os dois outros modelos (não-limiares). ${ }^{3}$

\section{AsSESSORANDO O RISCO}

Avaliar risco não significa simplesmente quantificar o perigo dèstinando proporções às centenas de milhares de indivíduos expostos a um determinado agente ambiental. Implica elevada incerteza (probabilidade) que, entre outros conceitos, varia enormemente, de acordo com o grau de importância dado pelo público (em geral, via órgãos formadores de opinião) ao fenômeno ou evento.

Morgan \& Henrion (1992), redesenhando o gráfico elaborado por Lichtenstein et al. (1978) (Gráfico 7), observaram que a heurística, mesmo operacionalizada junto a uma população mais esclarecida, estabelece resultados bastante tendenciosos (enviesados), fora da realidade dos fatos. Os casos de botulismo, por exemplo, estariam sendo superestimados pela população entrevistada, ao passo que os derrames cerebrais, subestimados. Os primeiros, largamente alardeados pela mídia, ao passo que os últimos sem despertar a devida importância na mesma.

No Brasil, em termos heurísticos, um paralelo pode ser traçado entre a importância dos óbitos por Aids e a mortalidade causada por diarréias em crianças com menos de um ano de idade.

Enquanto alguns riscos são bem conhecidos e entendidos pelo grande público, outros, como os riscos químicos, passam despercebidos. A morte anual por algumas atividade corriqueiras, por exemplo, são de domínio público. A morte por acidente automobilístico para um motorista habitual seria 1:4.000. Para um ciclista cotidiano, esta seria de 1:30.000, ao passo que para fumantes inveterados desde os 15 anos de idade a morte por câncer de pulmão seria de 1:800. Ainda na década de 70, Crouch \& Wilson (1986) demonstram, utilizando a árvore de falhas/acertos, a probabilidade de morte por riscos comuns e inusitados como os apresentados no Quadro 2.

Como o risco químico dispõe de reduzido senso comum - é menos conhecido - e quase sempre embasado em extrapolações de dados obtidos em animais de laboratório, $o$ objetivo maior da avaliação será estimar o excesso de risco causado por exposição ao agente químico acima da qual o risco existe, ainda que a exposição ao agente não ocorra.

Assim, sabe-se que a exposição a xenoestrógenos, hormônios-símiles ambientais (Aril (Ah)-agonistas e antagonistas) capazes de gerar um leque de alterações no sistema reprodutor de mamíferos, nas últimas duas décadas têm sido responsabilizados por mais de um caso de

3 Para mais informaçōes sobre tais conceitos, consultar o capítulo 4. 
GRÁFICO 7 - Número de mortes anuais medidas e estimadas pela opinião pública. Em geral, a acorrência de mortes por causas mais freqüentes está subestimada, enquanto as causas menos freqüentes estão superestimadas pelo público. Como exemplo, observem o número de casos de óbitos por botulismo e por derrame (acidente vascular cerebral)

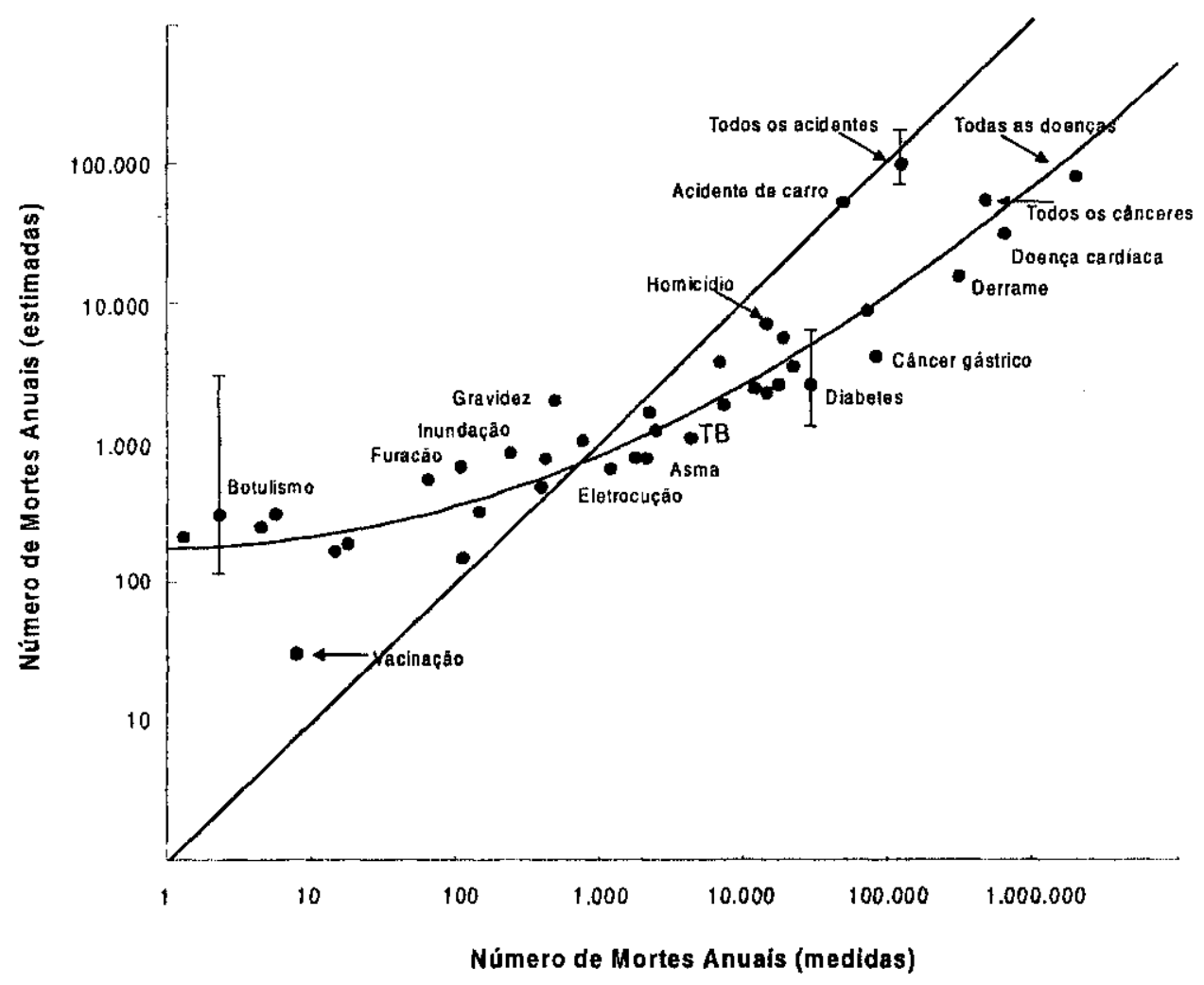

Fonte: CROUCH \& WILSON (1986).

câncer de mama em cada mil mulheres americanas (Davis \& Bradlow, 1995). No entanto, há que se diferenciar, por exemplo, a incidência desse tipo de câncer na presença e na ausência desses hormônios, que neste caso denuncia que o excesso desses tumores deve ter sido provocado pela estimulação endócrina dos tecidos, ativando a taxa de replicação do DNA e, dessa forma, aumentando o número de mutações, possivelmente carcinogênicas, que se multiplicam sem o devido reparo gênico.

Como já dito anteriormente, risco toxicológico significa probabilidade medida ou estimada de que um evento nocivo à saúde venha a ocorrer por exposição a um xenobiótico. Como se refere à probabilidade de ocorrência, o risco é expresso como fração, sem uma unidade de 
medida específica. O espectro de valores varia do zero (ausência absoluta de risco) ao 1, quando há a total certeza de que o risco irá acontecer. Assim, o valor que estiver entre zero e 1 será interpretado como a probabilidade com que o risco poderá ocorrer. O cálculo de probabilidades também inclui o risco em excesso da população exposta, em comparação com a não-exposta.

\section{QUADRO 2 - Risco anual de mortes associado com diversas atividades e} graus variados de exposições

Atividade/Exposição

Risco Anual (mortes/

100 mil pessoas em risco)

Motociclismo

2.000

Qualquer causa/Qualquer idade

1.000

Tabagismo (Qualquer causa)

300

Tabagismo (Câncer)

120

Combate ao fogo (Bombeiros) 80

$\begin{array}{ll}\text { Paraquedismo (Asa-Delta) } & 80\end{array}$

Mineraçäo (Carvão) $\quad 63$

Trabalho rural $\quad 36$

$\begin{array}{ll}\text { Veículo automotor } & 24\end{array}$

Peão de rodeio 3

$\begin{array}{ll}\text { Incêndio } & 2,8\end{array}$

$\begin{array}{ll}\text { Água clorada* } & 0,8\end{array}$

$\begin{array}{ll}\text { Manteiga de amendoim }(\sim 60 \mathrm{~g} / \mathrm{dia})^{* *} & 0,8\end{array}$

$\begin{array}{ll}\text { Carne de churrasco }(100 \mathrm{~g} / \mathrm{dia})^{* * *} & 0,5\end{array}$

$\begin{array}{ll}\text { Inundações } & 0,06\end{array}$

$\begin{array}{ll}\text { Queda de raio (relâmpago) } & 0,05\end{array}$

$\begin{array}{ll}\text { Queda de meteorito } & 0,000.006\end{array}$

* Nos niveis máximos permitidos de clorofórmio.

** Nos niveis máximos permitidos de aflatoxina.

*** Benzopirenos.

Fonte: CROUCH \& WILSON (1986). 
Quando postulamos, por exemplo, que a exposição ambiental crônica de uma criança a níveis elevados de chumbo $(>10 \mu \mathrm{g} / \mathrm{dl})$ deverá provocar um decréscimo de seu quociente intelectual numa razão de 1:100.000, isto implica afirmar que uma em cada 100 mil crianças (expostas versus não-expostas) terá seu desenvolvimento intelectual psicométrico afetado pela exposição ao agente. Crianças bem dotadas intelectualmente (Q.I.>130), que compõem uma faixa reduzida da população, se permanecerem com teores elevados de $\mathrm{Pb}$, poderão apresentar acentuado déficit neurocognitivo, distúrbios de comportamento e aprendizado, igualando-se em Q.I. à média da população ( 100) (Gráfico 8). Silbergeld (1996) relata que nestes casos não conseguiu-șe estipular, até o momento, um 'limiar' para tais efeitos.

GRÁFICO 8 - Freqüência de Distribuição Cumulativa de Q.Is. verbais de crianças com baixa ou elevada concentraçāo de chumbo na dentina

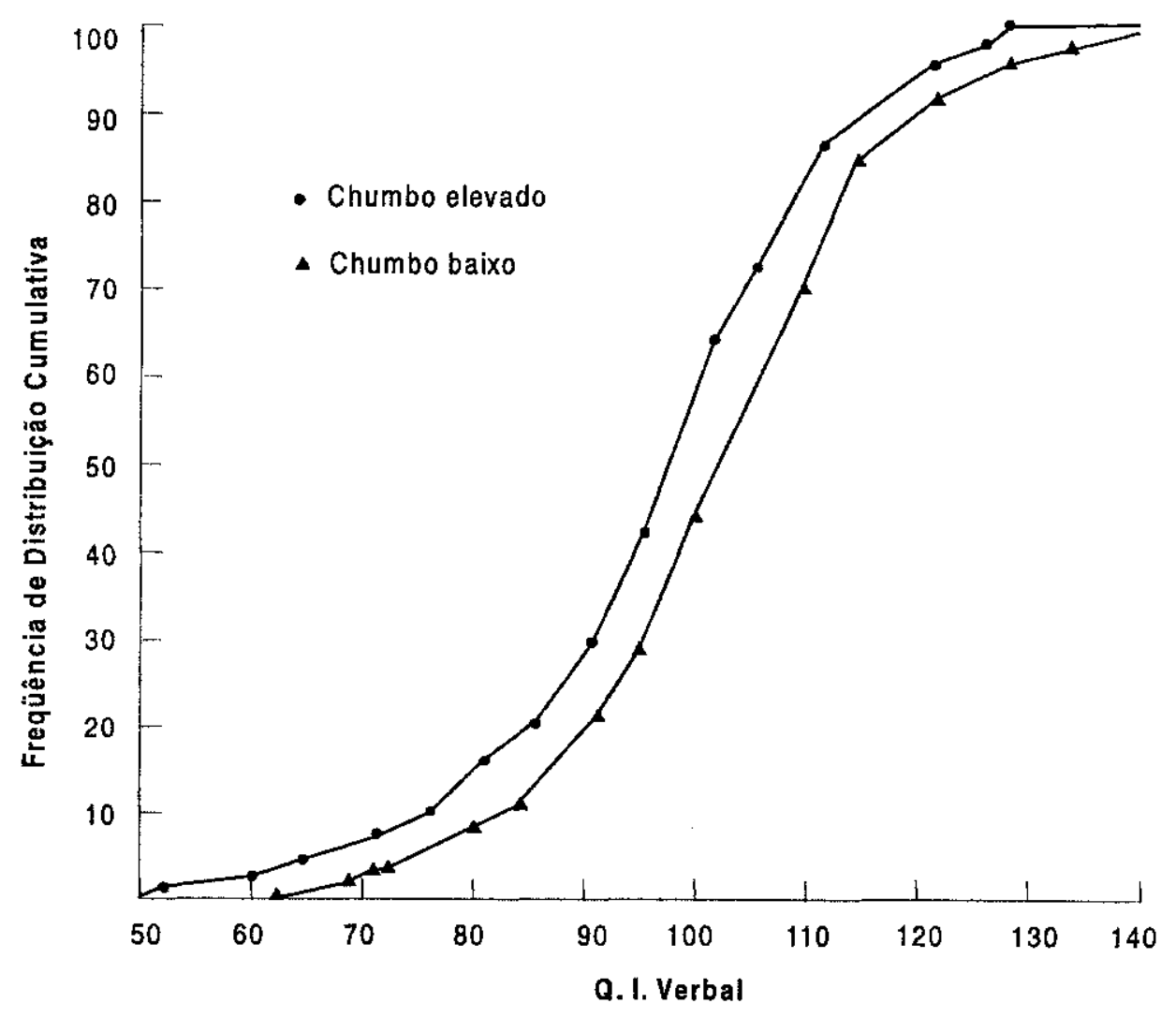

Fonte: NeEdLEMAN et al. (1979). 
Todavia, o exemplo anterior deixa bem claro que não se deve confundir Risco com Fator de Risco. Por exemplo, a obesidade não necessariamente ocasiona doenças cardíacas, mas é considerada um fator de risco. Por conseguinte, obesos têm maior chance de adquirir doenças cardiovasculares, ainda que possam existir outros fatores correlatos. $O$ importante a relevar é a verdadeira contribuição do fator para que o risco venha a ocorrer.

Especialistas no assunto têm também que ser hábeis o bastante para lidar com o leque de incertezas que se impõe quando se trata de risco químico na área da saúde ambiental.

Em geral, nesta situação o jargão epidemiológico é o mais utilizado, de modo que risco relativo e risco absoluto por agentes químicos são aleatoriamente auferidos sem a devida parcimônia da dúvida. Para superar as incertezas lança-se mão de valores de referência inespecíficos (default) que podem suprir esta base de conhecimento ou como dados científicos de produtos cujos valores (indicadores de saúde ou doença, por exemplo), estejam indisponíveis.

Tomadores de decisão devem, portanto, preestabelecer as escolhas que nortearão suas conclusões em uma Avaliação de Risco, incluindo a maior probabilidade possível de incerteza (aplicando a distribuição de Monte Carlo ou hipercubo latino, por exemplo) em cada opção, contribuindo assim para a diminuição de erro grosseiro ou fortuito.

Não tão somente a partir de dados científicos obtidos, mas várias hipóteses de trabatho e modelos de extrapolação aplicados revelaram que o risco de se contrair câncer ingerindo água clorada, ainda que cientificamente plausível, não foi submetido a nenhuma bateria de testes empíricos, não sendo, portanto, comprovado.

Em trabalho recente, Jo, Weisel \& Lioy (1990) consideraram todos estes aspectos quando estudaram a concentração de resíduo de clorofórmio na água para consumo humano, que seria capaz de causar um excesso de cânceres ao longo da vida em uma população de um milhão de pessoas. De acordo com índices de cloração da água empregados $(24 \mu \mathrm{g} / \mathrm{l})$, concluíram que 122 pessoas que se banham por dez minutos/dia em água clorada se expõem ao risco de adquirir câncer no curso de suas vidas, por meio da absorção dérmica e inalatória do clorofórmio, da mesma forma que a concomitante ingestão de um copo/dia $(150 \mathrm{ml})$ ou de $2 \mathrm{~L} /$ dia de água clorada nesta concentração irá teoricamente incrementar o risco, respectivamente para 153 ou 300 pessoas com câncer na mesma população, risco relativamente baixo e, por conseguinte, difícil de se demonstrar. $O$ que significa dizer que a maioria das Avaliações de Risco Toxicológico são ainda hipóteses de trabalho com grande conteúdo especulativo, geralmente carecendo de estudo epidemiológico de ordem prática, no qual os avaliadores baseiam suas ações ora em regulamentos legais, ora na prudência.

Entretanto, há que se considerar que na tomada de decisão sobre um problema, qualquer intervenção política antes de um consenso, abalizado por especialistas no assunto, não minimiza a incerteza científica. Porém, isso não desqualifica este tipo de estudo que, na realidade, de alguma forma responde aos anseios da população, carente de respostas sobre o tema, ante a pressão seletiva imposta por ambientes contaminados por substâncias químicas. 


\section{REFERÊNCIAS BIBLIOGRÁFICAS}

Couto, R. C. S. Hidrelétricas e Saúde na Amazônia: um Estudo sobre a Tendência da Malária na Área do Lago da Hidrelétrica de Tucuruí-PA, Brasil, 1996. Tese de Doutorado, Rio de Janeiro: Ensp/Fiocruz.

Craighead, T. E. Pathology of Environmental and Occupational diseases. St. Louis: Mosby-Year Book Inc., 1995.

CROUCH, E. \& WILsON, R. Informing and educating the public about risk. Risk Analysis, $6: 403-415,1986$.

DAVIS, D.L. \& BRADLOW, H. L. Can environmental estrogens cause breast cancer? Scientific American, 273(10):166-172, Oct. 1995.

Gossel, T. A. \& BRICKER, J. D. Principles of Clinical Toxicology. 3.ed. New York: Raven Press, 1994.

HENRION, M. \& FISCHOFF, B.Assessing uncertainty in physical constants. American Journal of Physics, 54(9):791-798, 1986.

Jo, W. K.; WeiseL, C. P. \& Lior, P. J. Choroform exposure and the health risk associated with multiple uses of chlorinated tap water. Risk Analysis, 10(4):58 1-585, 1990.

Kelly, K. A. \& CaRdon, N. C. The myth of $10^{-6}$ as a definiton of acceptable risk. EPA atch, 3(17):4-8, 1994.

KLIGERMAN, A. D. et al. Analysis of cytogenetic damage in rodents following exposure to simulation ground water contaminated by pesticies and a fertilizer. Mutation Research, 300:125-134, 1993.

LiCHTENSTEIN, S. et al. Judge frequency of lethal events. Journal of Experimental Psychology: Human Learning and Memory, 4:551-578, 1978.

Morgan, M. G. \& Henrion, M. Uncertainty. New York: Cambridge University Press, 1992.

NEEDLEMAN, M. D. et al. Deficit in psycological and classment performance of children with elevated dentine lad level. New England Joumal of Medicine, 300:689-695, 1979.

PlatT, A. The resurgence of infectious diseases. World Watch. Technical Report, p.26-32, Jul./Aug., 1995.

PratT, J. W. \& ZeCKHAUSER, R. J. Willingness to pay and the distribution of risk and wealth. Technical Report, EEPS, J. F. Kennedy School of Government, HarvardUniversity, Feb.1994.Rodricks, J. V. Calculated Risks. New York: Cambridge University Press, 1992. 
SILBERGELD, E. K. Nature and extent of lead exposures and toxicity in the Americas. In:

Howson, C. P. et al. Lead in the Americas: a call for action. Mexico City: Institute of Medicine (NAS/USA) and National Institute of Public Health (Mexico), 1996.

VACA-MIER, M. \& CALDAS, L. Q. A. Residuos peligrosos, medio ambiente y salud. Technical Report. ECO/OPS, Toluca, Mexico, Dec. 1995.

Yang, R, S. H. Toxicology of Chemical Mixtures. San Diego: Academic Press, 1994.

WeDEEN, R. P. et al. Clinical application of in vivo tibial K-X ray fluorescence for monitoring lead stores. Archives of Environmental Health, 50(5):355-361, 1995. 



\section{AVALIAÇÃO DE RISCO PARA A SAÚDE HUMANA \\ E ECOSSISTEMAS}

LENE HOLANDA SADLER VEIGA HORST MONKEN FERNANDES

\section{Avaliação de Risco à Saúde Humana}

A atual ênfase dada à Avaliação de Risco, uma metodologia introduzida nos últimos 15 anos, tem sido atribuída ao interesse mundial em se definir uma metodologia ampla, na qual se possa incluir os vários aspectos relacionados à toxicidade das substâncias, unindo causas e efeitos de uma maneira quantitativa. Os esforços para identificar falores de risco já vêm de longo tempo, dos quais a menor tolerância pública à exposição a substâncias potencialmente prejudiciais e o aumento das enfermidades congênitas têm motivado o estudo dos possíveis fatores ambientais associados à etiologia destas alterações (Vega, 1985).

A metodologia de Avaliação de Risco tem sido amplamente utilizada em problemas dc poluição ambiental, como ferramenta importante no processo do gerenciamento ambiental (Oliveira et al., 1987; Hoffman et al., 1991, Johnson, 1989; Blaylock et al., 1993). A metodologia proposta pela Agência de Proteção Ambiental Americana (U.S. EPA, 1989) incorpora, para os poluentes nāo-radioativos, o conceito de dose, há muito tempo utilizado na área de radioproteção. De maneira genérica, dose pode ser definida como a quantidade de uma substância incorporada ou absorvida pelo organismo (WHO, 1978), ou no caso da radiação, a energia média depositada pela radiação ionizante no elemento de matéria $m$ (ICRU, 1980). Logo, na avaliação da dose é fundamental a quantificação da exposição a um contaminante ou radiação.

Atualmente, no Brasil, o controle da qualidade do meio ambiente em relação aos poluentes não-radioativos é realizado comparando-se as concentraçōes encontradas nos corpos d'água com as concentrações máximas permitidas pela legislação (CoNAMA, 1986). Estc tipo de abordagem não considera a quantificação da exposição da população, isto é, os hábitos populacionais, o tipo de uso 'efetivo' que a população faz do ambiente, assim como as taxas de ingestão. Tais fatores são especílicos para cada região ou grupos populacionais, que variam significativamente, devendo, portanto, ser quantificados. Foran 
(1990) demonstra em seu trabalho a importância de se incorporar as diferenças nos hábitos populacionais, para a derivação dos critérios de qualidade de água.

O uso de valores genéricos de limites de concentração como unidade regulatória para contaminantes, tem-se mostrado inconsistente com o conceito de risco. Estratégias adotadas para a redução de poluentes num meio, baseadas somente nos limites de concentraçăo, podem resultar em alto custo nas táticas de controle de poluiçãão, porém o resultado final, em termos de redução do risco, pode ser desprezível. Isto se deve, principalmente, ao fato de os limites de concentração não levarem em conta a combinação de efeitos adversos devido à presença de vários contaminantes. Quando vários contaminantes estão presentes em concentraçōes próximas aos valores-limites, o efeito combinado pode ser substancialmente pior do que quando apenas um contaminante excede o valor-limite (U.S. EPA, 1986a).

A probabilidade de uma substância produzir efeito adverso está relacionada, primeiramente, com a sua potencialidade intrínseca de produzir efeitos tóxicos e, depois, com a susceptibilidade da população exposta. De maneira geral, os efeitos podem ser de dois tipos: sistêmicos e carcinogênicos. Os poluentes sistêmicos são aqueles que produzem efeitos tóxicos outros, que não sejam câncer ou mutação gênica. Os poluentes carcinogênicos são aqueles capazes de induzir uma modificação celular e iniciar um processo carcinogênico (U.S. EPA, 1986b).

A toxicidade sistêmica é tratada de forma a se estabelecer um limiar de exposição (uma fronteira abaixo da qual não serão observados os efeitos adversos). A existência de um limiar é uma das características que distingue os efeitos das toxicidades sistêmicas das mutagênicas e das carcinogênicas, já que estes últimos são tratados como processos sem um limiar definido.

Para os efeitos de toxicidade carcinogênica, é admitida a hipótese de que mesmo uma única molécula ativa de um carcinógeno que alcance o DNA da célula, pode induzir uma modilìcação celular e iniciar um processo carcinogênico. Esta hipótese implica que, pelo menos teoricamente, não existe uma dose totalmente segura. Tal mecanismo é tido como sem limiar, de forma que não existe um nível de exposição para um poluente que não gere uma pequena, mas finita, probabilidade de gerar uma resposta carcinogênica.

Todos os radionuclídeos são considerados carcinógenos humanos devido à possibilidade de indução de câncer pela radiação ionizante. Entretanto, para o urânio, a toxicidade química é maior que a radiológica, sendo os efeitos de toxicidade sistêmica o critério limitante no qual deve se basear o controle da exposição a este contaminante (Wrenn et al., 1985; Fisenne, Perry \& Harley, 1988).

A determinação da presença do risco e sua potencial magnitude, tendo em vista a saúde humana, é realizada durante o processo de Avaliação de Risco, constituído basicamente de quatro etapas:

- identificação do risco;

- avaliação dose-resposta;

- avaliação da exposição;

- caracterização do risco. 


\section{IDENTIFICAÇĀO DO RISCO}

É a primeira etapa da Avaliação de Risco e consiste em se determinar o grau de toxicidade de um agente. A exposição a um dado agente, dependendo da dose, pode resultar em uma variedade de efeitos tóxicos. Estes efeitos podem variar desde a morte de um organismo até pequenas mùdanças bioquímicas, fisiológicas ou patológicas (Barnes \& Dourson, 1988). Para se determinar o tipo de efeito adverso e sob que forma e em que tipo de exposição um agente apresenta um determinado efeito, são utilizados estudos epidemiológicos e com animais de laboratório. Para a maioria das substâncias químicas existe uma escassez de informações apropriadas sobre os potenciais efeitos em humanos. Nestes casos, os principais estudos são baseados em experimentos conduzidos em mamíferos não humanos, mais freqüentemente em ratos, camundongos, coelhos, hamsters, cachorros e macacos. Os estudos epidemiológicos, quando disponíveis, são prioritários, servindo os estudos em animais apenas para complementá-los.

A identificação do risco é, portanto, uma avaliação qualitativa do risco. No caso da radiação, os estudos epidemiológicos nos sobreviventes da bomba atômica de Hiroshima e Nagasaki, em grupos de trabalhadores expostos à radiação e em pacientes tratados com radioterapia, não deixam dúvida a respeito da capacidade das radiações ionizantes de induzir o câncer. As evidências dos efeitos de câncer para baixas doses e baixas taxas de doses são incompletas e os estudos em humanos fornecem apenas uma orientação para a estimativa do risco para baixas doses (BEIR III, 1980).

\section{AvaliaçÃo Dose-RESPOSTA}

A 'avaliação dose-resposta' é baseada na relação da dose com a resposta individual a esta dose. De maneira geral, observações têm revelado que com o aumento da dosagem de um agente tóxico, há um aumento na resposta, em termos de severidade e de incidência do efeito. Logo, nesta etapa, deve-se, primeiramente, decidir qual a resposta tóxica crítica a ser medida e definir exatamente a dose associada, seja dose absorvida ou administrada. Assim como para outros contaminantes ambientais, a maioria dos dados disponíveis de exposição à radiação ionizante são de exposição a altas doses e altas taxas de dose. A relação doseefeito para baixas doses e baixas taxas de dose de radiação tem de ser estimada através da extrapolação dos dados observados para altas doses.

A relação dose-efeito descreve a intensidade de um efeito adverso em relação à intensidade da dose para um período específico de exposição. Por outro lado, a relação dose-resposta descreve a proporção das respostas individuais em relação à intensidade da dose para um período específico de exposição. Dentro deste aspecto, é de extrema importância a necessidade de se conhecer os limiares para a relação dose-efeito, a fim de se garantir que a exposição de indivíduos ou de uma população não exceda a dose para a qual existe a possibilidade de ocorrência de efeitos adversos.

O resultado destas duas etapas de 'Identificação do risco' e 'Avaliação dose-resposta' irão determinar os valores de referência para efeitos de toxicidade sistêmica e carcinogênica. 
Destas duas avaliações surgem os valores de Dose de Referência - RfD, para toxicidade sistêmica, e o fator potencial de câncer - slope factor, para toxicidade carcinogênica. Os valores de dose de referência e de slope factors aprovados pela EPA são listados no IRIS -Integrated Information System (IRIS, 1993).

\section{Critérios para Efeitos de Toxicidade Sistêmica - RfD}

A toxicidade sistêmica é tratada de forma que se possa estabelecer um limiar de exposição (uma fronteira abaixo da qual não são observados efeitos adversos). Esta caracterização distingue os pontos terminais sistêmicos dos mutagênicos e carcinogênicos já que os últimos são tratados como processos sem um limiar definido.

A Agência de Proteção Ambiental Americana (Environmental Protection Agency U.S.EPA) utiliza o fator Dose de Referência (RfD) como substituição ao conceito de ingestão máxima aceitável (ADI), tendo em vista a necessidade de se evitar termos considerados prejudiciais do ponto de vista regulador, tais como 'aceitável' e 'seguro'.

A dose de referência (RfD) vem de encontro à necessidade de se mudar a filosofia de dose segura e de se utilizar uma dose de referência na qual se devem basear as decisões e não uma dose máxima aceitável. Pode ser definido como uma estimativa (com incerteza de até mais de uma ordem de grandeza) de exposição diária de uma população humana (incluindo os grupos sensíveis) que provavelmente não apresenta risco de efeitos adversos durante toda a vida. É expresso em miligrama por quilograma de peso corpóreo por dia, de acordo com a equação:

$$
R f D=\frac{N O A E L}{F I F M}
$$

Onde:

NoAel (No Observed Adverse Effect Level - dose sem efeito adverso observado) é uma dose, determinada experimentalmente, na qual não existe nenhuma indicação estatística ou biologicamente significativa do efeito tóxico. Os valores de NoAELs são obtidos a partir de estudos com populações humanas (investigações epidemiológicas) e estudos em laboratório com animais. Em vários experimentos relativos a uma mesma substância, com diferentes valores de NoAEL, geralmente se usa o maior deles e quando este não foi determinado experimentalmente é utilizado o LOAEL (Lowest Observed Adverse Effect Level - dose para o menor efeito adverso observado), dose também determinada experimentalmente, responsável pelo menor efeito adverso observado.

FI é o Fator de Incerteza que reflete os vários tipos de dados usados para estimar o RfD, geralmente múltiplos de 10.

Os Fatores de Incertezas são padronizados, de forma que para cada RfD gerado, sejam conhecidas as incertezas inerentes ao seu desenvolvimento. São definidos da seguinte forma: 
$10 \mathrm{H}$-Por conta da variação na sensibilidade entre membros da população (velhos, desnutridos, doentes...).

$10 \mathrm{~A}$-Por conta da incerteza de extrapolação de dados obtidos com estudos em animais para o homem.

10 S - Na extrapolação de estudos realizados com exposição não-crônica para exposição crônica.

$10 \mathrm{~L}$ - Usado quando o RTD for derivado do LOAEL ao invés do NOAEL.

FM é um Fator Modificador que reflete um julgamento profissional. Trata-se de um Fator de Incerteza adicional maior do que zero e menor ou igual a 10. A magnitude do valor de FM depende da avaliação protissional das incertezas científicas do estudo, não explicitamente tratadas nos fatores de incertezas. No caso onde não existe a necessidade de mais este Fator de Incerteza, o valor de omissão para FM é 1 .

Os valores de RfD são calculados dependendo basicamente de três aspectos:

- via de exposição - oral ou inalação;

- efeito crítico - tóxico ou relativo ao desenvolvimento;

- duração da exposição - crônica, subcrônica ou eventual.

De acordo com estes aspectos, são definidos:

- RfD crônico (RfDc) - deve ser usado para avaliar o efeito potencial não-carcinogênico associado com períodos de exposição superior a sete anos e ao longo de toda a vida.

- RfD subcrônico (RfDs) - caracteriza efeitos potenciais não carcinogênicos associados com exposições médias (períodos de exposição de duas semanas até sete anos).

- RfD relativo ao desenvolvimento (RfDdt) - avaliar o potencial efeito adverso que uma substância possa causar em um organismo em desenvolvimento, como resultado de uma exposição antes da concepção, durante o desenvolvimento pré-natal ou pós-natal até o período de maturação sexual.

Os RfDs para exposição oral e para inalação são calculados com base nos NOAEL oral $_{\text {al }}$ e NOAEL $_{\text {inaląăono }}$ respectivamente. Muito embora o método de abordagem utilizado na derivação destes RfDs seja o mesmo, a extrapolaçăo dos resultados experimentais em animais para o homem é mais complexa na exposição por inalação que na exposição oral, devido à dinâmica do sistema respiratório e sua diversidade entre as espécies, assim como às diferenças nas propriedades físico-químicas dos contaminantes. 
Critérios para Efeitos de Toxicidade Carcinogênica - Fator Potencial de CÂNCER (SLOPE FACTOR)

A carcinogênesc, ao contrário dos efeitos de toxicidade sistêmica, é considerada como um processo para o qual a Avaliação de Risco baseada em um limiar é inapropriada (IARC, 1987). A avaliação do risco carcinogênico consiste basicamente de duas ctapas: primeiramente, uma avaliação qualitativa é realizada, contendo uma revisão de todas as informações biológicas e químicas que suportam se um agente pode ou não causar uma resposta cárcinogênica. Os estudos são avaliados de acordo com considerações biológicas e estatísticas, descritas em várias publicações, como IARC (1987), Tomatis et al. (1978), Ashby \& Tennant (1991), Cabral (1985) e Ito et al. (1989). Nesta etapa, os agentes testados são classificados de acordo com um peso da evidência.

Na detcrminação do peso da evidência, os dados disponíveis em estudos com animais e humanos são avaliados separadamente. Para cada um destes dados a evidência é classificada como: suficiente, limitada, inadequada, ausência de dados ou evidência sem efcito. Com base na extensão com que um agente tem mostrado ser um carcinógeno, nos experimentos em animás ou humanos, ou cm ambos, cle é classificado com um peso da cvidência, conforme o seguinte quadro:

\section{QUADRO 1 - Classificação do peso da evidência para carcinogenicidade}

GRUPO DESCRIÇÃO

A

B1 ou B2

B1

B2

C

D
Carcinógeno humano.

Provável

carcinógeno humano.

Indica que os dados em humanos são limitados.

Indica suficiente evidência em animais e evidências inadequadas ou sem evidências em humanos.

Possível carcinógeno humano.

Não classificado como carcinógeno humano.

FONTE: U.S. EPA (1989a). 
Em uma segunda etapa, para aquelas substâncias classificadas no peso da evidência como carcinógenas ou potencialmente carcinógenas, são determinados fatores potenciais de câncer (slope factors).

Na segunda parte da avaliação de toxicidade para efeitos carcinogênicos, é gerado um fator potencial de câncer para a substância reconhecida ou provavelmente carcinógena. É calculado para as classes A, B1 e B2, podendo ser estimado, também, para a classe C.

O desenvolvimento de um fator potencial de câncer geralmente requer a aplicação de um modelo matemático no conjunto de dados disponíveis, para extrapolar a resposta das doses relativamente altas administradas nos experimentos com animais (ou das exposiçöes observadas nos estudos epidemiológicos), para os níveis de exposição mais baixos, esperados no contato do homem com a substância no meio ambiente (Armitage \& Doll, 1961; Bailer el al., 1988; Zapponi, Loizzo \& Valente, 1989).

Em geral, ć adolada a hipótese de linearidade para baixas doses, sendo o risco diretamente proporcional à dose; o risco é zero somente quando a dose é zero.

Após os dados serem ajustados ao modelo apropriado, o limite superior da função linear estimada, com 95\% de confiançă é calculado. Tal valor, conhecido como o fator potencial de cîncer (slope factor), representa o limite superior com 95\% de confïança na probabilidade de resposta por unidade de incorporação durante toda a vida. Isto é, existem apenas $5 \%$ de chance de que a probabilidade da resposta seja maior que o valor estimado. É evidente cue esta abordagem implica, intrinsecamente, na possibilidade de superestimativa do risco. No entanto, tal conservadorismo é justificado como forma de se controlar as incertezas e de garantir a segurança.

Todos os radionuclídeos são classificados como carcinógenos humanos. A U.S. EPA tem derivado valores de fatores incrementais para substâncias orgânicas e inorgânicas consideradas carcinógenas, tendo recentemente começado a estabelecer tais valores para serem utilizados para os radionuclídeos. Para ambos os radionuclídeos e contaminantes químicos, os valores de fator potencial de câncer são obtidos através da extrapolação de dados experimentais e epidemiológicos. Para os radionuclídeos, os dados cpidemiológicos em humanos formam a base da extrapolaçâa, ao passo que, para muitos carcinógenos químicos, os dados experimentais são a base para a extrapolação. Outra dilerença fundamental entre os dois é que os valores dos fatores potenciais para os carcinógenos químicos geralmente representam um limite superior com $95 \%$ de confïança, enquanto os valores de slope factors para os radionuclídeos são a melhor estimativa do valor do parâmetro (U.S. EPA, 1989).

O valor do fator potencial para substâncias carcinogênicas é dado em termos de risco por massa da substância em contato com o organismo, por unidade de peso corpóreo, por unidade de tempo (risco/(mg/kg/dia)); para os radionuclídeos, o valor do fator potencial é dado em termos de risco por unidade de atividade (risco/Bq). 


\section{AvaLIAÇão dA EXPOSIÇÃo}

O objetivo da 'avaliação da exposiçāo' é determinar ou estimar a frequêencia, magnitude, duração e as possíveis vias de exposição ao poluente (U.S. EPA, 1986a). A estimativa da exposição pode ser baseada diretamente em medidas ambientais ou estimada pelo uso de modelos específicos para as condiçōes existentes. Esta avaliação pode ser dividida em três etapas:

- Caracterização do cenário - compreende a definição de características gerais do local, da população e das fontes de exposição. Características básicas do local tais como clima, vegetação, hidrologia de águas subterrâneas e localização de águas de superfície (rios, lagos, mares, lagoas ou represas). A população exposta também deve ser identificada e descrita no que diz respeito às características que influenciam a exposição, tais como localização, hábitos populacionais e a presença de grupos sensíveis (crianças, velhos, doentes).

- Identificação das vias de exposição - nesta etapa são identificadas as vias de exposição pelas quais a população selecionada anteriormente pode vir a ser exposta. Isto é feito com base nas possíveis fontes, tipos e localização de lançamentos, assim como a localização e atividades da população potencialmente exposta.

- Estimativa da exposição - é estimada a concentração do poluente que entrará em contato com os indivíduos da população pelas diversas vias de exposição. Esta estimativa podeser realizada baseada em dados ambientais disponíveis para o local, como por exemplo dados de monitoramento, ou pela utilização de modelos matemáticos para estimar as concentrações nos locais ou compartimentos para os quais não se dispõe de medidas.

A incorporação, como medida da exposição, pode ser expressa de duas formas: Incorporação Diária Crônica (IDC) e Incorporação Diária Subcrônica (IDS). A primeira delas é baseada numa exposição estimada por um longo período de tempo (mais que sete anos) e a Incorporação Diária Subcrônica em uma exposição por um período específico (de duas semanas a sete anos).

\section{CaRActerização do Risco}

A caracterização do risco serve como ponte entre a avaliação do risco e o gerenciamento do risco e é, portanto, uma etapa-chave no processo de tomada de decisão. Deve conter não somente a apresentação da estimativa quantificada do risco, como também uma discussão e interpretação dos resultados para ajudar no julgamento do significado do risco (U.S. EPA, 1986c).

Nesta última etapa do processo de Avaliação de Risco, a avaliação da exposição e da toxicidade são resumidas e integradas em expressões quantitativas e qualitativas do risco. 
Tendo em vista que os mecanismos de toxicidade são diferentes para os efeitos carcinogênicos e para os não-carcinogênicos, as abordagens para a quantificação do risco também são diferentes.

\section{RIsco para Toxicidade Não-CarcinogêNICA}

A quantificação do risco, utilizada pela EPA para descrever o potencial de toxicidade sistêmica, não é expressa em termos de probabilidade. Em lugar disto, os efeitos potenciais não-carcinogênicos são avaliados pela comparação da dose decorrente da exposição em um período específico com a dose de referência (RfD) derivada para o mesmo período. Esta razão entre a exposição e a dose de referência é chamada de Quociente de Risco para o poluente $\mathrm{p}\left(\mathrm{QR} \mathrm{P}_{\mathrm{p}}\right)$ e é definida como:

$$
Q R_{p, a}=\frac{I_{p, a}}{R f D}
$$

Onde:

$\mathrm{RfD}=$ Dose de referência $(\mathrm{mg} / \mathrm{kg}$.dia) . kg.dia).

$I_{p, a}=$ Incorporação diária do poluente $p$ no alimento $a$, crônica ou subcrônica (mg/

$$
I_{p, a}=\frac{T_{x a .} C_{p, a .} F E \cdot D E}{P C \cdot T M}
$$

Onde:

$\mathrm{tx}_{\mathrm{a}}=$ Taxa de ingestão do alimento $a(\mathrm{~kg} / \mathrm{dia})$.

$\mathrm{C}_{\mathrm{p}, \mathrm{a}}=$ Concentração do poluente $p$ no alimento $a(\mathrm{mg} / \mathrm{kg})$.

$\mathrm{FE}=$ Freqüência da exposição.

$\mathrm{PC}=$ Peso corpóreo $(\mathrm{kg})$.

O Quociente de Risco assume que existe um nível de exposição abaixo do qual é improvável, mesmo para populaçōes mais sensíveis, a ocorrência de efeitos adversos à saúde. Se o nível de incorporação exceder este limiar (isto é, se I/RfD >1), estará indicando que o contaminante pode vir a ser importante para efeitos potenciais não-carcinogênicos. Como regra, quanto maior o valor do $\mathrm{QR}$ acima da unidade, maior o nível de importância. 


\section{ÍNDICE dE RISCO PARA EXPOSIÇÕES MÚLTIPLAS}

Enquanto alguns riscos ambientais envolvem exposições significativas a apenas um determinado poluente, outros envolvem exposições seqüenciais e simultâneas a uma mistura de poluentes que podem induzir efeitos similares ou diferentes. Para avaliar os efeitos potenciais causados por múltiplas substâncias no meio ambiente, a EPA assume a aditividade de dose, quando não existirem informações sobre a toxicidade das substâncias combinadas. Possíveis efeitos de sinergismo, aditivismo e antagonismo estão sendo estudados nas avaliações para mistura de duas ou mais substâncias (U.S. EPA, 1986c).

Logo, para avaliar o potencial de efeitos não-carcinogênicos, causados por mais de uma substância, uma aproximação é feita pelo Indíce de Risco (IR), que é a soma de todos os Quocientes de Risco, de acordo com a equação seguinte (U.S. EPA, 1986c):

$$
I R_{v}=\sum_{p} Q R_{p}
$$

\section{Onde:}

$\mathrm{IR}_{\mathrm{V}}=$ Índice de Risco para vários poluentes.

$\mathrm{QR}_{\mathrm{p}}=$ Quociente de Risco para o poluente $p$.

A estimativa da exposição às múltiplas vias é dada pelo Índice de Risco total, de acordo com a seguinte equação:

$$
I R_{t o t a l}=\sum_{v} I R_{v}
$$

Onde: sição.

$\mathrm{IR}_{\text {tutal }}=$ Índice de Risco total devido às múltiplas substâncias e às várias vias de expo-

$$
\mathrm{IR}_{\mathrm{v}}=\text { Índice de Risco devido às múltiplas substâncias para a via de exposição } v \text {. }
$$

Esta abordagem assume que exposições simultâneas, mesmo que individualmente abaixo de um determinado limiar, podem resultar em um efeito adverso à saúde. Existem várias limitações a este tipo de abordagem que devem ser comentadas:

- O nível de importância do IR não aumenta linearmente à medida que se aproxima ou excede a unidade, tendo em vista que os quocientes de risco são combinados para substâncias com RfDs baseados em efeitos críticos de várias significâncias toxicológicas e diferentes fatores de incerteza. 
- A abordagem de aditividade da dose é mais apropriadamente aplicada a compostos que induzam o mesmo tipo de efeito pelo mesmo mecarismo de ação. Conseqüientemente, a aplicação do índice de risco a um número de compostos que não induzem o mesmo tipo de efeito ou que não ajam pelo mesmo mecanismo, pode superestimar os efeitos potenciais. Esta aproximação, entretanto, é apropriada em nível de uma triagem preliminar - screening.

- Estas limitações geralmente não são de grande importância quando somente uma ou ou duas substâncias conduzem o índice de risco acima da unidade. Se o índice de risco for maior que a unidade, como consequiência da soma de vários quocientes de risco, é mais apropriado separar os compostos, por efeitos e por mecanismos de ação, e derivar índices de risco para cada grupo.

\section{RISCo CarCINOGÊNICO}

Tendo em vista a hipótese de linearidade para a curva dose-resposta em baixas doses, o valor do slope factor é constante e o risco será diretamente relacionado à exposição. A forma linear da equação de risco carcinogênico para baixas doses, que é usualmente aplicada para estimat os riscos ambientais, é dada por:

$$
R C=I C D . S F
$$

Onde:

RC = Probabilidade de um indivíduo desenvolver câncer devido à exposição a um carcinógeno.

ICD = Incorporação Crônica Diária de um carcinógeno ao longo de toda a vida (70 anos). Dado em mg/kg/dia.

$\mathrm{SF}=$ Slope Factor (fator potencial) para o carcinógeno $(\mathrm{risco} /(\mathrm{mg} / \mathrm{kg} / \mathrm{dia}))$.

Devido ao fato de o fator potencial ser geralmente um limite superior com $95 \%$ de confiança da probabilidade de resposta, o risco carcinogênico estimado será na maioria das vezes, uma superestimativa.

\section{Risco Carcinogênico para Exposições Múltiplas}

A estimativa do incremento de risco de câncer para a exposição simultânea a vários carcinógenos é dada pela soma dos riscos individuais (U.S. EPA, 1986b), de acordo com a equaçāo: 


\section{RISCO $_{m}=\Sigma$ RISCO $_{p}$}

Onde:

Risco $_{\mathrm{m}}=$ Risco carcinogênico para múltiplas substâncias (unidade de probabilidade).

Risco $_{p}=$ Risco carcinogênico para a substância $p$.

Esta equação representa uma aproximação da equação real que define a combinação de riscos para um mesmo indivíduo desenvolver um câncer como conseqüência da exposição a dois ou mais componentes. A diferença entre ela e a real não é significativa para risco de câncer total menor que 0,1 . Logo, é apropriada para a maioria dos riscos ambientais (U.S. EPA, 1989a).

Esta abordagem assume independência de ação pelos compostos envolvidos. Isto é, assume que nảo existe sinergismo ou antagonismo e que todos os compostos produzem o mesmo efeito (câncer). A probabilidade de um indivíduo vir a desenvolver um câncer devido à exposição a mais de um carcinógeno representa a probabilidade de ação de pelo menos um dos carcinógenos (U.S. EPA, 1989).

Quando são conhecidos os efeitos potenciais carcinógenos das substâncias combinadas, o slope factor é estimado de forma que os possíveis efeitos sinergéticos ou antagônicos estejam embutidos. Logo, o risco que uma mistura apresenta pode ser maior ou menor que a soma dos riscos individuais das substâncias.

De uma maneira geral, nas exposições ambientais, um indivíduo ou uma população estão expostos através de várias vias de exposição. A EPA assume que o risco para várias vias de exposição é aditivo, desde que seja para os mesmos indivíduos de uma população e para o mesmo período de exposição. Logo, o risco para várias vias de exposição que atetam conjuntamente o mesmo indivíduo ou população no mesmo período de exposição, são somados de acordo com a equação:

\section{$R I S C O_{\text {total }}=\sum_{v} R I S C O_{p, v}$}

Onde:

Risco $_{\text {total }}=\quad$ Risco de câncer total devido às múltiplas substâncias para as várias vias de exposição. ção $v$.

Risco $_{p, v}=\quad$ Risco de câncer devido às múltiplas substâncias para a via de exposi-

Esta aproximação, feita para a soma dos riscos carcinogênicos de várias substâncias e múltiplas vias de exposição, apresenta basicamente duas limitações principais: 
- Os limites de $95 \%$ da distribuição de probabilidades do slope factor não são estritamente aditivos. Quando os riscos de vários carcinógenos são somados, o risco total de câncer estimado pode tornar-se artificialmente mais conservativo. Quando os carcinógenos somados englobam radionuclídeos e substâncias químicas, passa a ser um problema ainda maior, tendo em vista que os valores dos fatores incrementais para radionuclídeos representam a melhor estimativa enquanto para substâncias químicas, representam o limite superior, com $95 \%$ de confiança.

- A equação de risco de câncer para múltiplas substâncias soma todos os carcinógenos igualmente, independente das classes A, B1 ou B2 (relativos ao peso da evidência). Valores de slope factors derivados de dados em animais passam a ter o mesmo peso do fator potencial derivado em humanos. Porém, se a contribuição ao risco total tiver um peso maior, somente pelos radionuclídeos ou um ou dois carcinógenos químicos, estes problemas não são tão significativos.

Se a contribuição de todos os carcinógenos for igualmente importante, devem-se separar os radionuclídeos dos carcinógenos químicos $\mathrm{e}$ avaliar as incertezas inerentes da estimativa do risco de cada un destes.

Todas estas incertezas devem ser apresentadas e avaliadas, assim como as incertezas inerentes aos modelos utilizados na estimativa da exposição e no cálculo do risco.

A estimativa do risco carcinogênico para radionuclídeos, baseado nos valores de slope factors, apresenta algumas limitaçōes quando comparada com a estimativa baseada no cálculo de dose e nos fatores de risco de câncer. A principal delas é o fato de os valores de slope factor serem derivados somente para o indivíduo adulto, enquanto que o cálculo de dose utiliza os fatores de conversão de dose que estão disponíveis para diferentes faixas etárias.

Os valores de slope factors são na verdade um cálculo inverso, isto é, ao invés de se ter o risco por unidade de dose efetiva (risco/Sv), calcula-se o risco por unidade de atividade incorporada ( $\mathrm{risco} / \mathrm{Bq}$ ), com base nos fatores de conversão de dose e no fator de risco.

Uma vez estimada a dose para a exposiçāo aos poluentes radioativos, o risco de câncer é estimado utilizando-se o fator de risco de câncer ponderado para sexo e idade de $0,05 /$ Sv, da ICRP (ICRP, 1991), e os fatores relativos de risco em razão da idade (Amaral, 1992; Rochedo, 1994), de acordo com a equação:

$$
R C=\sum_{I} H_{E}(I) \cdot R R \cdot R
$$

Onde:

$\mathrm{RC}=$ Risco carcinogênico - risco de um indivíduo vir a desenvolver um câncer devido à exposição à radiação ionizante.

$H_{E}(\mathrm{I})=$ Dose efetiva na idade (I) $-\mathrm{Sv} /$ ano.

$\mathrm{RR}=$ Risco relativo em função da idade. 
$\mathrm{R}=\quad$ Fator de risco da ICRP $-(0,05 / \mathrm{Sv})$.

$\mathrm{I}=\quad$ Idade no início da exposição.

Os fatores relativos de risco, $\mathrm{cm}$ virtude da idade, levam em consideração que, para uma dada exposição à radiação, a sensibilidade biológica em relação à indução de efeitos somáticos é maior para jovens do que para os mais idosos (Amaral, 1992).

\section{Avaliação do Risco Ecológico}

Com relaçāo a risco ecológico, as avaliações devem compreender:

- rclevância biológica;

- relevância para a sociedade;

- não apresentarem valores ambíguos;

- proverem previsões acessíveis.

A relevância social $\mathrm{tcm}$ sido enfatizada, uma vez que as avaliações de riscos relativos a insetos, zooplâncton, ou outros organismos que não sejam percebidos pela sociedade como sendo importantes, provavelmente nāo influenciarāo tomadas de decisão pelos órgãos competentes, a menos que possam representar riscos para peixes, vida selvagem, colheitas ou florestas. Alguns exemplos de impactos ccológicos podem ser citados:

- Redução na abundância e na produção de peixes tanto para uso comercial quanto recreacional

Impactos em espécies de peixes consumidos pelo homem estão entre aqueles de maior relevância social $\mathrm{cm}$ ambicntes aquáticos. Estas espécies são também importantes indicadores da saúde ecológica de ecossistemas aquáticos. Muitos dos peixes consumidos, especialmente aqueles com finalidade recreacional, são predadores no clo superior das cadcias alimentares aquáticas; estes predadores estão freqüentcmente entre as primeiras espécies a desaparecer como resultado de distúrbios no meio.

- Desenvolvimento de populações de algas que comprometem o uso da água

Florações (blooms) indesejáveis de algas são comumente obscrvadas em lagos e rescrvatórios como conseqüência da introdução de excesso de nutrientes, representando um incômodo para residentes vizinhos a cstes corpos d'água, pois podem afetar a população de peixes e causar gosto c odor em águas para consumo humano. Muito embora as mudanças 
na abundância e na concentração relativa de nutrientes inorgânicos sejam responsáveis pelos blooms, estes também podem ser provocados pela redução na atividade do zooplâncton que, por sua vez, é sensível a substâncias químicas tóxicas.

- Redução na produção de madeira e mudanças indesejáveis na composição de uma floresta

As florestas têm valor econômico, estético e recreacional óbvios, assim como valores indiretos. $\mathrm{O}$ valor econômico agregado é aquele mais facilmente quantificável. Os valores estéticos e recreacionais das florestas podem ser relacionados à produção primária em virtude da preferência geral por florestas maduras com árvores grandes. Entretanto, clorose e necrose induzidas por efeitos de poluição nas folhas das árvores também se constituem em importantes impactos estéticos, mesmo quando uma redução na sua produção não pode ser detectado. Os valores indiretos das florestas são possivelmente mais difíceis de analisar. Estes valores incluem erosão e controle do fluxo superficial, remoção e desintoxificação de poluentes, bem como a moderação do clima regional. Apesar de a produção ter sido utilizada como um índice de valores indiretos, a estrutura da comunidade e composição são aspectos claramente importantes a se considerar.

- Redução na vida selvagem

A vida selvagem é avaliada como forma recreacional e objeto de várias formas não-destrutivas de apreciação. Caça, apreciações (turismo ecológico, por exemplo) são formas de recreação econômica e psicologicamente importantes. Efeitos de poluentes na vida selvagem podem resultar da intoxicaçāo direta, modificação do hábitat ou na dinâmica da cadeia alimentar.

\section{Métodos para Avaliação de Risco Ecológico}

Informações diretas sobre riscos à população na natureza, comparáveis a dados de epidemiologia humana, são raramente disponíveis e freqüentemente de difícil obtenção. Para o caso de efeitos ecológicos de substâncias químicas tóxicas, é necessário extrapolar estimativas de risco a partir de testes de toxicidade realizados em laboratório ou a partir de experimentos de campo (muito raros ainda). A quantidade, qualidade e aplicabilidade dos testes disponíveis varia muito com relação às diferentes substâncias químicas. Adicionalmente, extrapolações a partir de dados gerados nos laboratórios mais qualificados são comprometidas por caracterizações incompletas da composição das espécies nos ambientes afetados, interações bióticas dentre as populações expostas e interações com outras perturbaçōes que afetam as populações expostas.

Dada a diversidade dos pontos de inferência (end-points) e a variedade dos tipos de dados que podem ser necessários, fica claro que nenhum método pode ser utilizado isolada- 
mente para se fazer todas as extrapolaçōes necessárias para todas as substâncias químicas e end points de interesse. Pode-se dizer, no entanto, que a confiança nas conclusões de uma Avaliação de Risco Ecológico aumenta se conclusões similares forem alcançadas por meio utilizando-se métodos independentes.

\section{Atributos de uma Metodologia de Avaliação de Risco}

Os métodos para estimativa de risco ecológico devem refletir um sólido fundamento em toxicologia ambiental. Os processos que determinam o transporte, degradação e acumulação de substâncias químicas no ambiente devem ser explicitamente representados. Uma formulação cuidadosa destes processos será fundamental na definição de estimativas de exposição, termo-chave na equação geral do risco ecológico. Os mecanismos biológicos que traduzem exposição em efeitos tóxicos em níveis apropriados da organização biológica devem ser formulados na metodologia. Este componente representa o complemento na previsão da exposição numa análise integrada de risco ecológico (Bartell, 1989). Numa perspectiva regulatória, o significado das estimativas de risco ecológico, proporcionadas pela metodologia, deve ser facilmente compreendido e adequado ao processo de tomada de decisão. Do ponto de vista científico, as estimativas do risco resultantes da metodologia devem ser consistentes com o conhecimento atual do nível de organização selecionado (indivíduo, população, comunidade, ecossistema ou regiões).

As estimativas de risco devem ser mensuráveis e verificáveis, pelo menos na teoria, usando-se para isso dados de programa de monitoração ou abordagens experimentais. É claro que modelos matemáticos e outros métodos de análise de sistema se tornam importantes nestas avaliaçōes.

\section{Exemplos de Métodos de AvaliaçĀo de Risco Ecológico}

\section{ANÁLISE DE EXTRAPOLAÇÃO DO ERRO}

A Análise de Extrapolação do Erro (AEE) é um método de cálculo da probabilidade de exceder um limite a ser usado naqueles casos no qual o limite considerado pode ser expresso como padrões toxicológicos. O método possui duas componentes: a extrapolação que é usada como uma estimativa do valor do limite a ser considerado a partir dos testes disponíveis e compreendendo as incertezas na estimativa; a componente de risco que calcula a probabilidade de se exceder o limite usando resultados das extrapolações.

Importante notar que é o cálculo da probabilidade de uma dada Concentração Ambiental exceder o limite (ao invés da simples comparação aritmética) que torna a AEE um verdadejro método de Avaliação de Risco.

O método consiste de cinco etapas:

- Definir o critério da Avaliação de Risco (a probabilidade de se causar reduções na produtividade de uma determinada espécie de peixe) em termos de um limite toxico- 
lógico (probabilidade de se exceder o valor de CMA - Concentração Máxima Aceitável para aquela espécie).

- Identificar a existência de dados para a substância química de interesse que esteja mais proximamente associada ao critério de avaliação (testes de $\mathrm{LC}_{50}$ para uma espécie semelhante, por exemplo).

- Quebrar a relação entre os dados e o critério de avaliação em etapas lógicas (por exemplo, de uma espécie para outra e dos dados de $\mathrm{LD}_{\mathrm{st}}$ para $\mathrm{CMA}$ ).

- Calcular as distribuições dos parâmetros do critério de avaliação a partir dos dados.

- Calcular o risco que uma concentração esperada venha a exceder o limite do critério de avaliação.

A primeira etapa depende da situação na qual a avaliação se processa e na formulação do problema pelo responsável pela avaliação; entretanto, a primeira, a segunda e a terceira etapas são muito limitadas pelo estado da arte no campo da toxicologia, que se traduz na disponibilidade de dados na literatura.

Um outro exemplo de Avaliação de Risco Ecológico pode ser encontrado no trabalho de Fernandes et al. (1994), que se baseia na metodologia desenvolvida por Hakanson (1980). A metodologia tenta relacionar as concentrações de poluentes nos sedimentos de fundos de um sisiema aquático ao risco de se observarem distúrbios no seu equilíbrio. Uma hipótese fundamental da metodologia é de que os organismos aquáticos num sistema eutrófico não irão receber a mesma dose de contaminantes que aquela relativa a um sistema oligotrótico. Tal hipótese se justifica, uma vez que os contaminantes na coluna d'água se ligarão preferencialmente ao particulado e à matéria orgânica dissolvida no sistema eutrófico, tornandose menos disponíveis para a biota e, conseqüentemente, exercendo menores graus de efeitos tóxicos.

Neste caso, o índice de risco ecológico é função dependente da sensibilidade do sistema aquático que, por sua vez, é função da sua produtividade. Na metodologia, o estado trófico é correlacionado com o conteúdo de nitrogênio ou fósforo do sedimento. Pode-se então definnir um índice de bioprodutividade (BPI), obtido a partir do coeficiente angular da curva entre a razão de fósloro ou nitrogênio, contra o teor de matéria orgânica no sedimento.

O potencial de risco ecológico para um contaminante individual é dado pela equação:

$$
E r_{i}=\operatorname{Tr}_{i} \cdot C_{i} f
$$

Onde:

$\mathrm{Er}_{\mathrm{i}}=$ Risco ecológico para uma dada substância.

$\mathrm{Tr}_{\mathrm{i}}=\mathrm{O}$ fator de resposta toxicológica para uma dada substância.

$C_{i} f=O$ fator de concentração da substância no sedimento. 
Os valores de $\operatorname{Tr}_{\mathrm{i}}$ para alguns metais pesados são apresentados na tabela a seguir:

Tabela 1 - Valores de $\operatorname{Tr}_{i}$ para alguns metais pesados

Metal

Valor de $\mathrm{Tr}_{\mathrm{i}}$

Cd

$30 . \sqrt{5} / \sqrt{I B P}$

$\mathrm{Pb}$

$5 \sqrt{5} / \sqrt{1 \mathrm{BP}}$

$\mathrm{Cu}$

$5 . \sqrt{5} / \sqrt{\mathrm{IBP}}$

$\mathrm{Cr}$

$2 \sqrt{5} / \sqrt{1 \mathrm{BP}}$

$\mathrm{Zn}$

$1 \sqrt{5} / \sqrt{\mathrm{IBP}}$

Fonte: Hakanson (1980).

Os valores de $\mathrm{C}_{i}$ f para cada espécie química são obtidos a partir da razão da concentração atual com valores de background (áreas não-contaminadas, níveis pré-industriais ctc.).

A soma dos fatores individuais de risco irá determinar o Índice de Risco (IR) para o sistema aquático em questāo. Sendo assim:

$$
\mathrm{RI}=\Sigma \mathrm{Er}_{\mathrm{i}}=\Sigma \operatorname{Tr}_{\mathrm{i}} \cdot \mathrm{C}_{\mathrm{i}} \mathrm{f}
$$

A seguinte terminologia pode ser utilizada para classificar o sistema aquático quanto aos valores de Índice de Risco:

IR $<150 \quad$ P Baixo risco ecológico para o sistema.

$150<\mathrm{IR}<300$ P Risco ecológico moderado para o sistema.

$300<\mathrm{IR}<600$ p Risco ecológico considerável para o sistema.

IR $>600 \quad$ D Risco ecológico muito alto para o sistema. 
Na presente metodologia o risco é definido como sendo:

Risco $=$ Probabilidade (Concentração Ambiental $>$ Limite)

Se admitirmos que a Concentração Ambiental (CA) e o Limite são independentes e log-normalmente distribuídos, então:

$$
\text { Risco }=\text { Prob }(\log \text { Limite }-\log \mathrm{CA}<0)
$$$$
=\operatorname{Prob}\left[\mathrm{Z}<[0-(\mu \mathrm{b}-\mu \mathrm{e})] /\left(5 \mathrm{~b}^{2}+\mathrm{se}^{2}\right)^{1 / 2}\right] \text {, }
$$

Onde:

$\left(\mu b, \mathrm{sb}^{2}\right) \mathrm{e}\left(\mu \mathrm{e}, \mathrm{se}^{2}\right)$ são a média e variância de $\log$ Limite e log $\mathrm{CA}$, respectivamente e $\mathrm{Z}=[(\log \mathrm{L}-\log \mathrm{CA})-(\mu \mathrm{b}-\mu \mathrm{e})] /\left(\mathrm{sb}^{2}+\mathrm{se}^{2}\right)^{1 / 2}$, uma variável randômica padrão com psi sendo sua função de distribuição cumulativa. No caso de se assumir CA como sendo constante e certa, aí o cálculo do risco se reduz a:

$$
\begin{aligned}
& \text { Risco }=\operatorname{Prob}\{\mathrm{Z}<[(\log \mathrm{CA}-\mu \mathrm{b}) / \mathrm{sb}]\}= \\
& \text { Psi }[(\log \mathrm{CA}-\mu \mathrm{b}) / \mathrm{sb}] .
\end{aligned}
$$

A partir desta definição, o risco depende da avaliação de CA (que pode ser derivada determinística ou probabilisticamente a partir de modelos matemáticos) e L, assim como das incertezas associadas (isto $\varepsilon$, de $\mu \mathrm{e}, \mu \mathrm{b}, \mathrm{se}^{2} \mathrm{e} \mathrm{sb}^{2}$ ). No caso de $\mathrm{L}$, a média e a variância podem ser estimadas por extrapolações matemáticas dos dados de toxicidade.

\section{EXTRAPOLAÇÃO}

No caso do cálculo das variâncias, reporta-se que um modelo de mínimos quadrados seria inadequado para o problema em questão. Recomenda-se a utilização de um modelo do tipo erro-nas-variáveis. Tal tipo de variância é o valor apropriado para se usar no cálculo dos intervalos de confiança e estimativa de risco porque o importante, aqui, é a certeza relativa a uma observação futura da variável de interesse, no caso um limite toxicológico, para uma combinação organismo-substância química não avaliada. Esta variância é maior (por um fator de $\mathrm{se}^{2}$ ) do que a variância da média, que, por sua vez, é maior do que a variância do coeficiente de regressão (número obtido pela maioria das calculadoras programáveis). Os intervalos de confiança calculados a partir desta variância são maiores do que aqueles convencionalmente reportados e são designados como intervalos de previsão.

Para facilidade do uso do método, o cálculo da variância pode ser reduzido à expressão:

$\operatorname{Var}\left(\mathrm{Y} / \mathrm{X}_{0}\right)=\mathrm{F} 1+\mathrm{F} 2\left(\mathrm{X}_{0}-\mathrm{X}\right)^{2}$, os valores de $\mathrm{F}_{1}$ e $\mathrm{F}_{2}$ obtidos a partir de tabelas. 
Todos os dados utilizados nas extrapolações são log-transformados e as variâncias reportadas, e intervalos de previsão são para os valores transformados. A transformação logarítmica é utilizada para aumentar a homogeneidade das variâncias à linearidade das relações.

Em alguns casos, é necessário fazer múltiplas extrapolações; o mais comum é a combinação de extrapolações aguda/crônica e taxonômica. Nestas circunstâncias, o termo Y da primeira extrapolação torna-se a variável independente na segunda extrapolação, e os parâmetros da segunda regressão $(\mathrm{z}=\mathrm{c}+\mathrm{dy})$ são determinados como no primeiro caso, isto é, substituindo-se y por $\mathrm{x}$ e z por $\mathrm{y}$.

A variância total para as duas extrapolações é:

$\operatorname{Var}(\mathrm{Z} / \mathrm{Xo})=\operatorname{var}(\mathrm{Z} / \mathrm{Yo})+\mathrm{d}^{2} \operatorname{var}(\mathrm{Y} / \mathrm{Xo})$

\section{ESTUDO DE CASO HIPOTÉTICO}

Como exemplo do uso do método de extrapolação, vamos considerar a estimativa do risco de se exceder o limite para efeitos crônicos em Salvelinus fontinalis a partir dos resultados de $\mathrm{LC}_{50}$ para Salmo gairdneri, da ordem de $5300 \mu \mathrm{g} / \mathrm{l}$ para uma substância química hipotética. A curva de extrapolação Salmo-Salvelinus tem a seguinte equação:

\section{Ysalvelinus $=1.10 \mathrm{Xsalmo}-0.33$}

Substituindo-se o log de 5300 na equação de extrapolação obteremos o valor de $\mathrm{LC}_{50}$ para Salvelinus igual a 3.77. Os valores de $\mathrm{F} 1$ e F2 são respectivamente iguais a 0.14 e 0.0 . O cálculo da variância passa a ser trivial uma vez que o termo $\mathrm{F}^{2}(\mathrm{Xo}-\mathrm{X})^{2}$ é igual a zero.

Assim, o valor de

$\operatorname{Var}(\mathrm{Y} / \mathrm{Xo})$ é igual a 0.14. A extrapolação de $\mathrm{LC}_{50}$ para CMA é dada pela equação:

$$
\mathrm{YCMA}=0.90 \mathrm{XLC}_{50}-1.16
$$

Obtém-se, desta forma, o valor de 2.22 para CMA relativo a Salvelinus com uma variância resultante desta extrapolação igual a 0.53 . Tomando-se a expressão para o cálculo da variância total chegaremos ao valor de 0.57 [0.14 + (0.81 x 0.53)].

Vamos supor agora que o log da Concentração Ambiental esperada seja igual a 2.0 com uma variância de 0.5 ; a probabilidade que o CMA para Salvelinus seja inferior à Concentração Ambiental é determinada pela equação:

Psi $\left[(\mu \mathrm{e}-\mu \mathrm{b}) /\left(\mathrm{sb}^{2}+\mathrm{se}^{2}\right)^{1 / 2}\right]$,

assim, $(2.0-2.22) /(0.57+0.50)^{12}=-0.21$ 
A probabilidade acumulada do valor de $Z$ (obtido tela Tábua de $Z$ ) é 0.42 . Assim, o risco que o limite para efeito crônico em Salvelinus seja excedido é igual a 0.42, ou seja, teremos uma confiança de $58 \%$ de que os efeitos crônicos não ocorram.

\section{Aplicação dos Conceitos - Formulação de Critérios de Qualidade de Água}

Os programas de critério de qualidade de água em alguns países, a exemplo do que ocorria nos EUA, baseavam-se na proteção à vida aquática. Ultimamente a comunidade científica tem dispensado atenção especial aos efeitos menos visíveis de impactos crônicos de poluentes tóxicos. Como exemplo, pode-se citar a acumulação de substâncias tóxicas nos tecidos de organismos aquáticos que podem causar danos à saúde humana e a outros organismos que consomem esta biota contaminada (Foran, 1990).

Os critérios numéricos definem limites de concentração de substâncias tóxicas em águas superficiais, acima dos quais podem acarretar num risco à saúde do homem e da biota aquática e terrestre. Servem também como medida regulatória para o controle das descargas de poluentes tóxicos a partir de fontes pontuais.

Se ao invés de se adotar valores nurnéricos de qualidade da água, utilizarmos expressões numéricas em que o critério de qualidade de água seja função de variáveis específicas locais, estaremos incorrendo nas seguintes vantagens, como postula Foran (1990):

- Facilidade de se levar em consideração as condições específicas regionais e/ou locais para onde estará sendo desenvolvida a atividade em questão.

- Facilidade de incorporação imediata de informações científicas disponíveis na literatura, especialmente quando for o caso de substâncias para as quais não se disponhám de critérios estabelecidos.

- Facilidade da participação popular na definição dos parâmetros que constarão nas formulações do(s) critério(s) de qualidade da água.

Duas formulações desta natureza são também propostas por Foran (1990). Uma para substâncias carcinogênicas e outra para substâncias não-carcinogênicas. 


\section{Critérlos de Quajdade de Água para Substâncias Carcinogênicas}

\section{CRItÉrio para Carcinogênese Humana}

(HCC - HuMAN CARCINOGENIC CRITERION) (Mg/L):

$$
H C C=\frac{R A I . W h}{W t+(F \cdot B C F)}
$$

Onde:

$\mathrm{RAI}=$ Risco Associado à Ingestão (dose) $\mathrm{em} \mathrm{mg} / \mathrm{kg} / \mathrm{dia}$, podendo ser definido através da fórmula ( $\mathrm{L} / \mathrm{q}^{*} \mathrm{x}$ nível de risco de câncer aceitável), onde $\mathrm{q}^{*}=$ slope factor.

$\mathrm{Wh}=$ Peso médio de um adulto $(70 \mathrm{~kg})$.

$\mathrm{Wt}=$ Consumo de água de um adulto $(2 \mathrm{~L} /$ dia $)$.

$\mathrm{F}=$ Taxa de consumo de peixe $(\mathrm{kg} / \mathrm{dia})$.

$\mathrm{BCF}=$ Fator de bioconcentração $(\mathrm{L} / \mathrm{kg})$.

\section{CRITÉrio de Qualidade de Água para Substâncias Não-CarcinogÊnicas} (HNC - HUMAN NONCARCINOGENIC CRITERION) (MG/L):

$$
H N C=\frac{R f D \cdot W h \cdot E A F}{W t+(F \cdot B C F)}
$$

Onde:

$\mathrm{RfD}=$ Dose de referência para o contaminante $(\mathrm{mg} / \mathrm{kg} / \mathrm{dia})$.

$\mathrm{EAF}=$ Fator de ajuste de exposição, adimensional, que regula a contribuição da exposição por outras vias que não a áquatica, tais como ar, solo, alimentos e água subterrânea. Assume valor unitário quando a única via de exposição for água superficial.

A escolha do nível de risco de câncer, o fator de ajuste de exposição para outras vias, assim como também os fatores, de bioacumulação são parâmetros que tornam específico o critério de qualidade de água para uma dada situação. São possíveis de ser discutidos com a sociedade podendo ser mais ou menos restritivos, da mesma forma que o nível de risco poderá variar de acordo com a percep̧̧ão do risco pela comunidade. Dependendo da escolha feita, os valores calculados podem variar em ordem de grandeza, como veremos no exemplo a seguir: 
Dispōe-se de uma lagoa onde são liberados os efluentes de uma indústria. Dentre as substâncias lançadas está o $\mathrm{Zn}$. Levando-se em consideração que esta lagoa abriga várias espécies de peixes que servem como base de alimentação da população local, quer se saber qual seria o critério de qualidade de água a ser adotado para este metal, a fim de que a população não seja exposta a riscos de efeitos adversos à saúde devido à ingestão de peixe.

$$
\begin{aligned}
& \mathrm{RfD}_{\mathrm{zn}}=2,00 \times 10^{-1} \mathrm{mg} / \mathrm{kg} / \mathrm{dia} \text { (IRIS, 1993). } \\
& \mathrm{Wh}=70 \mathrm{~kg} \text { (Foran, 1990). } \\
& \mathrm{BCF}=4,0 \times 10^{2} \text { (Fernandes, Bidone \& Veiga, 1994). } \\
& \mathrm{F}=0,050 \mathrm{~kg} / \mathrm{dia} \text { (Hoffman, 1991). }
\end{aligned}
$$

Além do valor de bioacumulação de zinco em peixe, obtido a partir de um estudo na região, adotaram-se diferentes valores da literatura, para estabelecer a faixa de variação que pode assumir o HNC, conforme a tabela seguinte:

\section{Tabela 2 - Derivação de critério de qualidade de água para o zinco}

\begin{tabular}{ll}
\hline $\begin{array}{c}\text { Fator de bioacumulação } \\
(\mathrm{L} / \mathbf{k g})\end{array}$ & $\begin{array}{c}\text { HNC } \\
(\mathbf{m g} / \mathrm{L})\end{array}$ \\
\hline $4,0 \times 10^{2}(\mathrm{a})$ & 0,70 \\
$1,0 \times 10^{3}(\mathrm{~b})$ & 0,28 \\
$1,98 \times 10^{2}(\mathrm{c})$ & 1,41 \\
\hline
\end{tabular}

a) Fernandes, Bidone \& Veiga (1994).

b) IAEA (1982).

c) Boldrin \& Pereira (1987).

A resolução Conama n² 20, de 18/06/86, estabelece o limite de $0,18 \mathrm{mg} / \mathrm{L}$ de $\mathrm{Zn}$ para águas salobras, visando a dar proteção à vida aquática e preservando a qualidade do consumo humano. Este valor é mais restritivo do que o menor valor calculado pela equação do HNC $(0.28 \mathrm{mg} / \mathrm{L})$. Todavia, algumas ressalvas devem ser feitas.

O HNC se baseia apenas na proteção à saúde humana, ao passo que os critérios de qualidade de água propostos pelo Conama visam também à proteção à vida aquática. Sendo assim, os potenciais efeitos tóxicos na biota aquática podem tornar o critério de qualidade de água mais restritivo do que se forem considerados apenas os efeitos adversos à saúde humana. Suter \& Rosen (1988) referem-se à concentração máxima aceitável de uma subs- 
tância tóxica na água - MATC (Maximum Acceptable Toxicant Concentrations) para zinco como sendo de $0,16 \mathrm{mg} / \mathrm{L}$, em um estudo com peixes (Mysidopsis bahia), valor próximo ao adotado na legislação para proteção à fauna aquática. Logo, se do ponto de vista da saúde humana seria possível admitir uma concentração mais elevada de $\mathrm{Zn}$ na água, tal concentração traria a possibilidade de causar efeitos adversos na comunidade aquática daquela lagoa.

Cabe ressaltar também que os valores de concentração a partir dos quais são observados efeitos adversos em peixes, em experimentos de laboratório, variam numa ampla faixa e estão relacionados com a dureza da água, a espécie e o estágio no ciclo vital, além do tempo de exposição ao metal, especialmente no que tange a concentraçōes subletais. 


\section{REFERÊNCIAS BIBLIOGRÁFICAS}

AMARAL, E. C. S. Modificação da exposição à radiação natural devido a atividades agrícolas $e$ industriais numa área de radioatividade natural elevada no Brasil, 1992, 130p. Tese de Doutorado: Rio de Janeiro: Instituto de Biofísica, Universidade Federal do Rio de Janeiro.

Armitage, P. \& Doll, R. Stochastic models for carcinogenesis. Proceedings of the Fourth Berkeley Symposium on Mathematical Statistics and Probability, 4. Lecan and Neyman: New York, 1961.

Ashby, J. \& Tennant, R. W. Definitive relationships among chemical structure, carcinogenicity and mutagenicity for 301 chemical tested by the U.S.NTP. Mutation Research, 257:229-306, 1991.

BAILER, J. C. III et al. One hit models of carcinogenesis: conservative or not? Risk analysis, 4:485-497, 1988.

Barnes, D. G. \& Dourson, M. Reference dose (RfD): description and use in health risk assessment regulatory. Toxicology and Pharmacology, 8:471-486, 1988.

BARTELL, S. M. Risk-based decision making in water resource. In: HAIMES, Y. Y. \& STAKHIV, E. Z. (Eds.) Ecological Risk Analysis. New York: American Society of Civil Engineers, 1989. p.224-239.

BEIR III. Committee on the Biological Effects of Ionizing Radiations; National Research Council: "The effects on the populations of exposure to low levels of ionizing radition". Washington, D.C.: National Academy Press, 1980.

BLAYLOCK, G. et al. White Oak Creek embayment site characterization and contaminant screening analysis. Oak Ridge National Laboratory (Environmental Sciences Division Publication n.3.821), Oak Ridge, 1993. 138p.

BoldRini, C. V. \& Pereira, D. N. Metais pesados na Baía de Santos e estuários de Santos e São Vicente - bioacumulação. Ambiente, 1(3), 1987.

CABRal, J. R. P. DDT: laboratory evidence. IARC Scientific Publications, 65, 1985.

Conselho Nacional do Meio Ambiente (Conama). Resoluções do Conama: 1984/1986. Secretaria Especial do Meio Ambiente (Sema), Brasília, 1986. 96p.

Fernandes $\mathrm{H}$. M. et al. Heavy metal pollution assessment in the coastal lagoons of Jacarepaguá, Rio de Janeiro, Brazil. Environmental Pollution, 85:259-264, 1994. 
Fisenne, I. M.; Perry, P. M. \& Harley, N. H. Uranium in Humans. Radiation Protection Dosimetry, 24:127-131, 1988.

Foran, J. A. Toxic Substance in Surface Water - Protecting human health: the Great Lakes experience. Environment Science Technology, 24:604-608, 1990.

HaKanson, L. An ecological risk index for aquatic pollution control. A sedimentological approach. Water Research, 14, 975-1001, 1980.

Hoffman, F. O. et al. Preliminary screening of contaminants in the off-site surface water environment downstream of the U.S. Department of Energy Oak Ridge Reservation. Environmental. Oak Ridge National Laboratory (Environmental Sciences Division Publication n.3.485), Oak Ridge, Martin Marietta Energy System, Inc., 1991.

InTERNATIONAL AgenCY For ReSEARCh ON CANCER (IARC). IARC Monographs on the evaluation of carcinogenic risks to humans. Supplement 7. Lyon, 1987.

U.S. Environmental Protection Agency (U.S. EPA).Guidelines for exposure assessment. Federal Register, 51:34041-34054, 1986a.

U.S. Environmental Protection Agency (U.S. EPA). Guidelines for carcinogen risk assessment. Federal Register, 51:33991-34003, 1986b.

U.S. Environmental Protection Agency (U.S. EPA). Guidelines for the health risk assessment of chemical mixtures. Federal Register, 51: 34013-34025, 1986c.

U.S. EnVIRONMENTAL PROTECTION AgenCY (U.S. EPA). Risk assessment guidance for superfund. Vol.I: Human Health Evaluation Manual. Oswer Directive 9285.7-01a, EPA Office of Emergency and Remedial Response, 1989.

VeGA, G. S. Evaluación Epidemiológica de Riesgos Causados por Agentes Químicos Ambientales. Toxicologia V: genotoxicidad no al sistema reprodutor, v. 11, Organización Mundial de la Salud, 1985.

World Health Organization (WHO). Principles and Methods for Evaluating the Toxicity of Chemical. Geneva: WHO, 1978.

WrenN, M. E. et al. Metabolism of ingested U and Ra. Health Physics, 48:601-633, 1985.

ZAPPONI, G.A.; LoIZZo, A. \& VALENTE, P. Carcinogenic risk assessment: some comparisons between risk estimates derived from human and animal data. Experimental Pathology, $37: 210-218$, 


\section{GLOSSÁRIO}

\section{AEE}

Aerossol

Allatoxina

Agenda 21

AIA

Alteragene

Análise contextual

Análise de equiuidade
Análise de Extrapolaçāo do Erro. Método de cálculo da probabilidade de exceder um limite a ser usado naqueles casos em queo limite considerado pode ser expresso como padröes toxicológicos.

Suspensão de pequenas partículas líquidas ou sólidas em meio gasoso.

Micotoxina calcinogênica produzida por um lungo, Aspergillus: flavas, presente em anendoim, nozes, castanhas em início de decompusiçĩo.

Documento elaborado pela Organizaçĩo das Nações Unidas (ONU), estabelecendo projeto de ação global visando ao desenvolvimento sustentável, foi adotado por chefes de Estado de 179 países participantes da Conferêneia das Nações Unidas sobre Meio Ambiente e Desenvolvimento, realizada no Rio de Janeiro, em junho de 1992.

Avaliação de Impacto Ambiental. Processo definido como um conjunto de procedimentos realizados para identificar, prever e interpretar, assim eomo para prevenir as conseqüências ou efcitos ambientais que determinadas açoes, planos, programas ou projetos poden cattsar à satúde, ao bem-estar humano e ao entorno.

Toda substância ou fator que provoque alteração do meio anbiente.

Envolve a comparação do risco em questão com um ou mais de um dos seguintes aspectos: com outro risco, com os benelícios de um produto ou de uma atividade e com os custos de reduçẫo do risco.

Procura analisar as iniqüidades existentes na distribuição do riseo, custos a benefícios relacionados com os diferentes grupos sociatis, com as dilerentes regiōes e com as gerações. 
Análise de preferência do público

Análise de Risco

Antagonismo

Antropogênica

APELL

AR

ARA

Aromático

Árvore de falhas
Envolve a comparação do risco percebido de acordo com os seguintes critérios: comparação com produtos existentes e aceitos ou com atividades possuindo um benefício similar, e com $o$ que as pessoas dizem acerca da aceitabilidade do risco.

Usada normalmente para a identificação de riscos nas diferentes unidades de produção, permite a elaboração de mapas de risco do meio ambiente interno e externo. O risco é calculado utilizando modelos para toxicidade, emissões líquidas ou gasosas, dispersão, incêndios e explosões. Os efeitos são calculados em razão da distância do ponto de ocorrência.

Interação entre duas substâncias químicas ou sistemas em que um reduz o efeito do outro.

De origem humana.

Alerta e Preparação de Comunidades para Emergências Locais. Manual preparado pela United Nation Environmental Proteccion (UNEP), sobre o processo de atendimento a acidentes tecnológicos.

Avaliação de Risco. Processo quantitativo e qualitativo conduzido para caracterizar a natureza e a magnitude dos riscos à saúde pública pela exposição a substâncias perigosas ou a contaminantes emitidos em sítios específicos; identificação do perigo, localização de suas causas, estimativa da extensão dos seus danos e a comparação destes com os benefícios. Existem várias outras definições para este termo.

Avaliação de Risco Ambiental. Processo de avaliação conjunta de dados científicos, sociais, econômicos e de fatores políticos que precisam ser considerados para a tomada de decisão sobre por exemplo a proibição, o controle ou a gestão de produtos ou atividades no meio ambiente.

Em química orgânica, composto que contém um ou mais radicais benzeno.

Diagrama em se que mostram as possíveis cadeias de eventos que levam ao aparecimento de um dano. 
Avaliação de Saúde

$\mathrm{BCF}$

Biodegradável

Bioensaio

Biotransformação

Câncer

Carcinogênese

Carcinógeno

Catástrofe

Catbrás
Baseada na informação da caracterização ambiental, nas preocupações da comunidade com a saúde e nos resultados dos efeitos nesta.

Fator de bioconcentração.

Capaz de ser metabolizado por um processo biológico ou orgânico.

Usado para dois fins distintos: o primeiro, mais apropriado, refere-se ao emprego de seres vivos para medir a quantidade do agente tóxico de uma amostra ou a toxicidade desta. O segundo relaciona-se ao emprego de animais para investigar os efeitos tóxicos de agentes em testes de toxicidade.

Reação metabólica ou sequiência de reações que em geral reduzem o potencial para efeito adverso de um xenobiótico (hidrólise, conjugação etc.).

Crescimento desordenado de células malignas de tamanho ilimitado que invade tecidos contíguos, disseminando-se para distintas áreas do corpo.

Processo afisiológico que envolve a conversão de células normais em neoplásicas c, postcriormente, de células neoplásicas em tumor. O processo pode ser resultado de ação química, vírus, radiação U.V. ou ionizante.

Agente causador de câncer. Pode ser tanto 'epigenético', quando excrce scus efeitos por citotoxicidade, imunossupressão, desequilíbrio hormonal etc., quanto 'genotóxico', quando envolve alterações de material genético.

Caso especial de risco direto em que a probabilidade de ocorrência do evento é baixa, mas suas conseqüências são muito prejudiciais.

Diretiva brasileira adaptada a partir da diretiva de Seveso, pela Companhia de Engenharia e Tecnologia de São Paulo (CETESB), que estabelece critérios de identificação e classificação do potentencial de risco de acidentes ambientais das atividades industriais. 
Cenário

CFCs

Chuvass ácidas

Cif

$\mathrm{CL}_{511}$

Clorado

Colinesterise

Conservação ambiental

$\mathrm{Cp}_{\mathrm{p}, \mathrm{a}}$

Desenvolvimento sustentável

Despoluir

Diretival de Seveso

Dosagem
Descrição e comprecndimento das interações dos diferentes compartimentos ambientais entre si, a extensão das suas comunicabilidades - no que diz respeito aos processos de transferência dos agentes poluidores lançados - no sítio em estudo;

Clorofluorcarbonos. Substâncias artiliciais contendo cloro. Săo utilizaddas en sistemals de refrigeraçũóo e em sprays, entre outros usos.

Acidificação das chuvas devido ao aumento de poluentes na atmosfera, especialmente os SOx e os NOx;

Fător de concentração da substância no sedimento.

Concentração letal de uma substância que, quando testadla experimentalmente, mata $50 \%$ da população em estudo. Ĺ expressa em $\mathrm{ml}$ ou $\mathrm{mg} / \mathrm{m}^{3}$.

Substância com um ou mais átomos de cloro presentes cm sua molécula.

Enzima existente cm mamíleros e em outros seres. É capaz de inativar a acetilcolina, entre outras substâncias.

Utilização de um recurso ambiental qualquer, de modo an se obter um rendimento consideritdo bom, garantindo-se, entretanto, suit renovação ou sua auto-sustentaçēô.

Concentração do poluente p no alimento a.

Processo de mudança no qual o uso dos recursos sustentáveis (duráveis), a direção dos investimentos, a orientação de desenvolvimento tecnológico e a açã̃o institucional servem para aumentar o potencia! de atender às necessidades humanas, tanto hoje como no futuro.

Retirar do meio exterior ajuilo que pode ser nocivo.

Diretiva que classifica os empreendimentos industriais quanto a scu grau de riseo e quanto aos efeitos quando de emissões acidentais.

Quantidade de substância química administrada ou ingerida relacionada a alguma função orgânica, geralmente expressa cm $\mathrm{mg} / \mathrm{kg}$ de peso/dia. Posologia. 
Dose

Dose de referência

EAF

Ecologia

Ecossistema

Efeito estufa

EHIA

EIA

ELF

End-points

Epidemiologia

Eri

Exposição

F

Farmacodinâmica
Quantidade total de um xenobiótico administrado ou ingerido.

Ver RfD.

Fator de ajuste de exposição, adimensional, que regula a contribuição da exposição por outras vias que não a aquática.

Ciência que estuda as relações entre os seres vivos e o meio ambiente, bem como suas recíprocas influências.

Sistemas integrados de seres vivos e ambientes tísicos.

Aquecimento global do planeta devido ao aumento da concentração de certos gases na atmosfera $\left(\mathrm{CO}_{2}, \mathrm{CH}_{4}, \mathrm{~N}_{2} \mathrm{O}, \mathrm{CFCs}\right.$, vapor d'água).

Environmental Health Impact Assessment. Estudo de avaliação de impacto na saúde ambiental, objetiva predizer e avaliar os impactos provocados pelo desenvolvimento baseado nos parâmetros ambientais que tenham uma forte interferência na saúde dos ecossistemas e principalmente na saúde humana.

Estudo de Impacto Ambiental. Identifica prováveis impactos do projeto, propõe medidas mitigadoras para os impactos inaceitáveis e também alternativas em conjunto com as medidas mitigadoras, para posterior tomada de decisão.

Campos eletromagnéticos de baixa freqüência.

Pontos de inferências ou terminais.

Ciência que estuda a causa, a distribuição e o controle de fatores que determinam a frequiência e a distribuição de um processo ou doença infecciosa em uma região.

Risco ecológico para uma dada substância.

Contato do homem ou animal com substância(as) química(as)/ biológica(as) ou radiações no meio ambiente ou no local de trabalho.

Taxa de consumo de peixe.

Medições de dose interna para se relacionar com efeitos. 
Farmacocinética

FE

FEL

FI

FM

Genotóxico

Gestão Ambiental

Gestão do Risco

$\mathrm{HCC}$

HE (I)

Herbicida

HNC

I

ICD

IDC
Medições de dose interna para se relacionar exposição com dose.

Frequêência da exposição.

Frank Effect Level. Nível de efeito tóxico aberto ou exuberante.

Fator de Incerteza que reflete os vários tipos de dados usados para estimar o RfD, geralmente múltiplos de 10.

Fator Modificador. É um fator de incerteza adicional maior que zero e menor ou igual a 10.

Capaz de danificar material genético (DNA) de células cujos efeitos mais conhecidos são os mutagênicos e os carcinogênicos.

Procedimentos cujos objetivos são a conservação dos meios físico e biótico e a dos grupos sociais que deles dependam.

Processo que inclui a seleção e implementação da ação regulatória mais apropriada, tomando por base os resultados do processo de Avaliação de Risco, do controle tecnológico disponível, da análise de custo-benefício, do risco aceitável, do número aceitável de casos, da análise dos fatores sociais e políticos.

Human Carcinogenic Criterion. Critério para carcinogênese humana.

Dose efetiva na idade (I).

Agente capaz de aniquilar plantas.

Human Noncarcinogeanic Criterion. Critério para não-carcinógenos humanos.

Idade no início da exposiçăa.

Incorporação Crônica Diária de um carcinógeno ao longo de toda a vida (70 anos).

Incorporação Diária Crônica baseada numa exposição estimada por um longo período de tempo (superior a sete anos). 
Identificação do perigo

IDS

Impacto

Inseticida

Ip,a

IR

IRv

ISO 14000

$\mathrm{LC}_{50}$

$\mathrm{LD}_{50}$

Letal

Limite de tolerância (TLV)

LOAEL

Maligno
Trata-se da identificação do agente perigoso na sua essência, seus efeitos, as condições de exposição e a população-alvo.

Incorporação Diária Subcrônica baseada numa exposição estimada por um período específico (de duas semanas a sete anos).

Qualquer alteração favorável ou desfavorável produzida por um produto, processo, ação ou atividade.

Agente que mata insetos.

Incorporação diária do poluente no alimento a, crônica ou subcrônica.

Índice de Risco. É usado para avaliar o potencial e os efeitos năo-carcinogênicos causados por mais de uma substância.

Índice de Risco para vários poluentes.

Série de normas que pretende estabelecer padrões para sistemas de gerenciamento, auditoria e rotulagem ambiental, avaliação de ciclo de vida de produtos e aspectos ambientais em normas de produtos.

O mesmo que $\mathrm{CL}_{50}$.

O mesmo que $\mathrm{DL}_{50}$.

Causador de morte.

Threshold Limit Value. Limite superior aceitável da concentração de substância em suspensão. Nessas condições, estima-se que os trabalhadores podem se expor ao agente sem qualquer prejuízo à saúde.

Lowest Observed Adverse Effect. Dose para o menor efeito adverso observado, que é uma dose também determinada experimentalmente, responsável pelo menor efeito adverso observado;

Altamente lesivo ou fatal. 
Meio ambiente

Metabolismo

Metástase

Mutagenicidade

Névoa ácida $(\mathrm{smog})$

NOAEL

NOEL

NOx

Organofosforado

PAH

PC

Perigo

Pesticida

Poluentes sistêmicos
Conjunto, a um dado momento, de agentes físicos, químicos, biológicos e de fatores sociais suscetíveis de provocar um efeito direto ou indireto, imediato ou a termo, sobre os seres vivos e as atividades humanas. Existem várias outras definições para este termo.

Soma total de reações bioquímicas que acontecem no organismo.

Disseminação de uma doença (câncer, por exemplo) para região do corpo fora do local de lesão.

São modificaçōes da hereditariedade induzidas na informação genética armazenada no DNA celular.

Indesejável mistura de gases formados na baixa troposfera pela ação da luz solar sobre os poluentes de origem humana, especialmente os NOx e os hidrocarbonetos. O ozônio é o principal composto produzido no smog.

No Orbserved Adverse Effect Level. Dose sem efeito observada. Dose determinada experimentalmente na qual não existe nenhuma indicação estatística ou biologicamente significativa do efeito tóxico.

No Observed Effect Level. Dose mais alta de um xenobiótico que, em determinado teste de toxicidade, é capaz de causar efciefeitos adversos detectáveis.

Óxidos de nitrogênio.

Pesticida orgânico com radicais fosfato, inibe a colinesterase.

Hidrocarbonetos poliaromáticos.

Peso Corpóreo.

Termo qualitativo que expressa o potencial nocivo do agente para a saúde e/ou para o meio ambiente.

Agente capaz de aniquilar praga ou peste.

Aqueles que produzem efeitos tóxicos outros que não o câncer ou a mutação gênica. 
Poluente

Poluição

Probabilidade

$\mathrm{QRp}$

RAI

$\mathrm{RC}$

Relatório Brundtland

$\mathrm{RtD}$

RfD crônico (RfDc)

RfD subcrônico (RfDs)

RIMA

Risco agudo

Risco ambiental
Contaminante primário ou secundário que contribui para a poluição.

Modificação prejudicial em um ambiente em que se encontra instalada uma forma de vida qualquer. Alteração do estado natural. Existem várias outras definições para este termo.

Proporção dos casos nos quais determinado evento ocorre.

Quociente de Risco para o poluente p.

Risco Associado à Ingestão.

Probabilidade de um indivíduo desenvolver câncer devido à exposição a um carcinógeno.

Documento que estabeleceu, pela primeira vez, uma correlação entre o meio ambiente e o crescimento econômico, também chamado desenvolvimento sustentável ou durável.

Dose de referência. Usado para toxicidade sistêmica, é definida como estimativa (com incerteza de até mais de uma ordem de grandeza) de exposição diária de determinada população humana (incluindo os grupos sensíveis) que provavelmente não apresenta risco de efeitos adversos durante toda a vida.

Usado para se avaliar o efeito potencial não-carcinogênico associado com períodos de exposição maior que sete anos e ao longo de toda a vida.

Caracteriza efeitos potenciais não-carcinogênicos associados com exposições médias (períodos de exposição de duas semanas até sete anos).

Relatório de Impacto Ambiental. Resumo do EIA, escrito em linguagem técnica mas acessível ao público.

Aquele decorrente de emissões de energia ou matéria em grandes concentrações, em um curto espaço de tempo.

Risco que ocorre no meio ambiente, seja ele interno - no caso de uma indústria, por exemplo - ou externo. 
Risco Carcinogênico (RC)

Risco crônico

Risco direto

Risco natural

Risco tecnológico

Risco tolal

Risco toxicológico

Risco

Risco p,v

RR

RTAs

Saúde ambiental

Saúde

Seletividade

Sensibilização)

SF
Probabilidade de um indivíduo desenvolver câncer devido à exposiçãa a um carcinógeno.

Aquele que apresenta uma ação contínua por longo período.

Probabilidade de que um determinado evento ocorra, multiplicada pelos danos causados por seus efeitos.

Aquele decorrente de distúrbios da natureza.

Aquele decorrente das atividades desenvolvidas pelo homem.

Risco de câncer total devido às múltiplas substâncias para as várias vias de exposição.

Probabilidade de algum efeito adverso ocorrer após exposição de organismos a um xenobiótico.

Medida da probabilidade e da severidade de efeitos adversos. Existem várias outras definições para este termo.

Risco de câncer devido às múltiplas substâncias para a via de exposição $\mathrm{v}$.

Risco Relativo em razão da idade.

Riscos Tecnológicos Ambientais.

Interdependência da saúde com os fatores socioeconômicos/ ambientais. Estudo da saúde do homem e dos ecossistemas.

Estado de completo bem-estar lísico, mental e social, não apenas a ausência de doença ou enfermidade.

Variação da toxicidade de uma substância de espécie para espécie ou de órgão para órgão.

Exposição inicial de um organismo a um hapteno/antígeno calpaz de desenvolver uma resposta imune.

Slope Factor. Fator potencial, usado para toxicidade carcinogênica. 
Sinergismo

SOx

Teratogênese

Termo Fonte

Tolerância

TOR

Toxicidade

Toxicologia

Toxina

Tri

Txa

UVR

Wh

Wt

Xenobiótico
Interação de duas ou mais substâncias na qual um agente aumenta $o$ efeito do outro.

Óxidos de enxofre.

Refere-se à indução de efeitos no processo embrionário ou fetal, aumentando a mortalidade ou gerando anomalias congênitas.

Processo linear no qual os efeitos à saúde, devido ao lançamento de materiais radioativos ou não, no meio, dependerão diretamente de suas quantidades e de suas formas.

Refere-se a situações no qual o organismo adquire capacidade de resistir à ação de um xenobiótico como resultante de exposição anterior.

Term of Reference. Escopo do projeto de impacto ambiental.

Efeitos adversos ou deletérios advindos de exposição curta ou longa a um determinado xenobiótico.

Ramo da ciência que estuda substâncias tóxicas de origem natural ou sintética.

Substância tóxica elaborada por um ser vivo.

Fator de resposta toxicológica para uma dada substância.

Taxa de ingestão do alimento.

Radiações ultravioletas.

Peso médio de um adulto.

Consumo de água por um adulto.

Termo genérico para descrever qualquer substância estranha ao organismo não contemplada pelos caminhos biológicos usuais. 
Formato: $16 \times 23 \mathrm{~cm}$

Tipologia: Times New Roman

Papel: Pólen Bold $70 \mathrm{~g} / \mathrm{m}^{2}$ (miolo)

Cartão Supremo $250 \mathrm{~g} / \mathrm{m}^{2}$ (capa)

Fotolitos: Laser vegetal (miolo)

Ruben Fernandes (capa)

Reimpressão e acabamento: Imprinta Gráfica e Editora Ltda.

Rio de Janeiro, maio de 2004.

Não encontrando nossos títulos em livrarias, contactar a EDITORA FIOCRUZ:

Av. Brasil, $4036-1^{\circ}$ andar -sala 112 - Manguinhos

21040-361 - Rio de Janeiro - RJ

Tel.: (21) 3882-9039 e 3882-9041

Telefax: (21) 3882-9006

http://www.fiocruz.br/editora

e-mail: editora@frocruz.br 